Division of Geological \& Geophysical Surveys

PRELIMINARY INTERPRETIVE REPORT 2002-5

\title{
SEDIMENTOLOGY AND HYDROCARBON SOURCE ROCK POTENTIAL OF MIOCENE-OLIGOCENE STRATA, MCGRATH QUADRANGLE: AN OUTCROP ANALOG FOR THE HOLITNA BASIN
}

\author{
by \\ David L. LePain ${ }^{1}$, Robert B. Blodgett ${ }^{2}$, and James G. Clough ${ }^{1}$ \\ ${ }^{1}$ Alaska Division of Geological \& Geophysical Surveys, 794 University Avenue, Suite 200, Fairbanks, AK 99709 \\ ${ }^{2}$ Oregon State University, Department of Zoology, Corvallis, OR 97331
}

February 2003

THIS REPORT HAS NOT BEEN REVIEWED FOR TECHNICAL CONTENT (EXCEPT AS NOTED IN TEXT) OR FOR CONFORMITY TO THE EDITORIAL STANDARDS OF DGGS.

Adobe PageMaker 7.0.Ink

Released by

STATE OF ALASKA DEPARTMENT OF NATURAL RESOURCES

Division of Geological \& Geophysical Surveys

794 University Avenue, Suite 200

Fairbanks, Alaska 99709-3645 


\section{INTRODUCTION}

This report summarizes the Alaska Division of Geological \& Geophysical Survey's (DGGS) Holitna Basin Shallow Gas project. The Holitna basin is located in southwestern Alaska, in the northeastern and northwestern quarters of the Sleetmute and Lime Hills quadrangles, respectively (Figure 1). The goal of the project was to evaluate the shallow gas potential of the Holitna basin to the extent possible given the absence of exposures of basin-filling strata and subsurface data (i.e. seismic reflection and test well data). A small gas resource in the basin could represent a significant source of energy for local use, particularly as a fuel for mine operations at the Donlin Creek prospect in the southern Iditarod Quadrangle (Fig. 1). This report does not address the economics of developing shallow gas in the Holitna basin.

With this goal in mind, DGGS developed a basin analysis approach that utilized outcrops of Tertiary strata in the southern McGrath Quadrangle that are presumed to be similar to the subsurface fill of the Holitna basin, and two potential field geophysical datasets (airborne magnetic data and a regional gravity survey). The Holitna basin is entirely a subsurface feature - its presence is inferred from regional gravity data that show an elongate northeast-trending, tear drop-shaped gravity low astride the Farewell fault zone (Kirschner, 1994; Meyer and Krouskop, 1984; Fig. 1). The relation, if any, between the Tertiary section in outcrop and the subsurface section in the Holitna basin is unknown. This poses a significant challenge in trying to assess the relevance of outcrop data to the stratigraphy of the Holitna basin and its shallow gas potential.

The objectives of this study include:

1. Utilize available geophysical datasets to evaluate the deep structure and sedimentary fill of the Holitna basin.

2. Conduct detailed stratigraphic studies of the Tertiary section exposed along the northwestern side of the Alaska Range [front] in southern and central McGrath Quadrangle to help evaluate the petroleum reservoir and source rock potential of the Tertiary section. This is based on the assumption that exposures of Tertiary strata represent an outcrop analog for the fill of the Holitna basin.

3. Attempt to relate the outcrop section in the McGrath Quadrangle to the subsurface Holitna basin. 
4. Use the above data to make inferences regarding the shallow gas potential of the Holitna basin (conventional gas and coalbed methane).

The following sections summarize the regional geology of both the Holitna basin and outcrop belt to the northeast, the stratigraphy and sedimentology of the Tertiary section in outcrop, reservoir potential of conglomerates and sandstones, organic geochemical data, and the petroleum potential of the Holitna basin inferred from outcrop studies.

\section{REGIONAL GEOLOGY AND PREVIOUS WORK}

The existence of the Holitna basin is inferred from regional gravity data that show a pronounced Bouguer gravity low in excess of -40 mGals (Meyer and Krouskop, 1984) (Fig. 1). This gravity low is situated astride the Farewell fault zone (Kirschner, 1994), the western continuation of the Denali fault system (DFS) in southwestern Alaska. Gravity modeling suggests a thickness of up to 4,600 m of Tertiary age sedimentary rocks in the basin (Smith and others, 1985; Cady, written communication, 2001). The magnitude of the gravity low decreases toward the northeast, suggesting a corresponding decrease in the thickness of the Tertiary strata. The basin is bounded to the north and west by outcropping Cretaceous strata of the Kuskokwim Group, and to the southwest, south, and east by outcropping Paleozoic strata of the Nixon Fork and Dillinger sequences (Farewell terrane of Decker and others, 1994) (Bundtzen and others, 1994; Decker and others, 1995; and Gilbert, 1981) (Fig. 1). No exposures of the basin fill are known from the interior of the basin or along the basin margin, and no subsurface data (e.g. well or seismic) are available. The character and age of the basin fill are thought to be similar to Tertiary strata exposed along the northwestern flank of the Alaska Range [front] in the McGrath Quadrangle northeast of the basin (Fig. 1).

Discontinuous exposures of Tertiary sedimentary rocks are present northeast of the Holitna basin from the upper Cheeneetnuk River, southwest of White Mountain, to the Little Tonzona River (Fig. 1). Geologic mapping by Bundtzen and others (1997), Dickey (1982), and Gilbert (1981) show Tertiary strata along this trend in fault-bounded slivers associated with the Farewell fault zone. Near the southwest end of the outcrop belt, Priestley (cited in Brooks, 1911) reported considerable quantities of lignitic coal in the valley of the Big River from his trip through the region in 1909. Sainsbury (1965) and Sainsbury and MacKevett (1965), working in the White Mountain-Cheeneetnuk 
River headwaters area a few kilometers west of the Big River, described at least 2,500 m (8,100 feet) of Cretaceous (?) conglomerate that they interpreted as down-faulted against older Paleozoic strata. These workers made no mention of coal or carbonaceous mudstone. Gilbert (1981) subsequently mapped these rocks (his map unit Tcg) and assigned a Tertiary age based on similarities with the Usibelli Group, a late Eocene to Miocene coal-bearing succession exposed in the foothills north of the central Alaska Range (Wahrhaftig and others, 1969; Wahrhaftig, 1987). Analysis of pollen samples recently collected from siltstones interbedded with the conglomerates suggest the Tertiary section near White Mountain is late Oligocene to possibly earliest Miocene (Ridgway and others, 2000). Our station 00DL56 corresponds to the exposure studied by Ridgway and others (2000).

W.H. Condon (cited in Barnes, 1967) reported a 2-m-wide exposure of bright, brittle coal along the bank of the Cheeneetnuk River, southwest of White Mountain, and stated that exposures of coal continue for several miles along the river. Gilbert (1981) mapped these exposures (his map unit uTs), located 17 to $25 \mathrm{~km}$ (10 to 15 miles) southwest of White Mountain, and considered them late Miocene in age based on plant megafossils (identified by the late Dr. Daniel Axelrod). Our station 00DL57 is located along a low, overgrown riverbank exposure on the north side of the Cheeneetnuk River, in Gilbert's (1981) unit uTs.

Herreid (1968) described exposures of pebble conglomerate on the west bank of the Windy Fork (Fig. 1) that he interpreted as Tertiary, but did not provide details on their stratigraphy (Fig. 1). Sloan and others (1979) subsequently measured and described the upper $268 \mathrm{~m}$ of the Windy Fork section (our station 00DL34), which includes thick intervals of claystone with numerous thin interbeds of bone (high ash content), bony coal (very high ash content), and coal, and several interbeds of sandstone.

Player (1976) conducted a helicopter reconnaissance of the Tertiary outcrop belt from the Cheeneetnuk River to the Little Tonzona River in 1970. Player (1976) provided the first description of the coal-bearing section in the Little Tonzona-Deepbank Creek area. According to Player, an isolated exposure with a total stratigraphic thickness of 60 $\mathrm{m}$ is present on the west bank of the Little Tonzona River, $30 \mathrm{~m}$ of which is clean subbituminous coal (our station 00DL28). Player described another exposure located 7 km west-southwest of the Little Tonzona River exposure, along an unnamed creek (tributary of Deepbank Creek, McGrath C-1 Quadrangle; our station 00DL43). Sloan and 
others (1979) measured and described the coal-bearing sections at both locations and provided coal quality data (proximate and ultimate analyses).

Dickey $(1982,1984)$ and Ridgway and others (2000) provided the first detailed sedimentologic descriptions of the Tertiary section in outcrop. Dickey (1982) recognized three distinct Tertiary units between the Windy and Middle Forks of the Kuskokwim River (Fig. 1), including from oldest to youngest: a conglomerate, sandstone, siltstone, shale, and coal unit (unit Tqa); a limestone conglomerate (unit Tcl); and a felsite conglomerate (unit $\mathrm{uTcf}$ ). The relative age of these units is inferred from field relations as no continuous section through the three units is known. Along the Windy and Middle forks Dickey $(1982,1984)$ measured 1,700 $\mathrm{m}$ and $650 \mathrm{~m}$, respectively, of conglomerate, sandstone, siltstone, shale, carbonaceous shale, and coal in map unit Tqa. The ages of Dickey's three map units are poorly constrained. Dickey $(1982,1984)$ cited an ARCO inhouse palynologic report that assigned an Oligocene age to Tertiary strata within his unit Tqa (location information is not provided). Solie and others (1991) reported a K-Ar date of 45.5 Ma (middle Eocene) from a dike that intruded coal-bearing mudstones between Windy and Middle forks. These mudstones occur in a fault-bounded mass approximately $1.5 \mathrm{~km}$ south of Dickey's unit Tqa (Solie and others, 1991). Dickey (1982 and 1984) did not provide information on the stratigraphy and sedimentology of units Tcl and uTcf.

High-angle faults mark the base of unit Tqa at both locations studied by Dickey, and the Tertiary strata at both places are overlain by a veneer of Quaternary outwash and Recent alluvium. At both locations Tertiary strata generally dip northward, with the exception that a southwest-trending synclinal axis is present near the north end of the Windy Fork exposure. There the northernmost $1 / 4$ mile of outcrop consists of southdipping strata. Dickey (1984) noted that the succession at both locations fines-upward and is capped by thick shale, carbonaceous shale, and coal sequences. Dickey (1984) interpreted the clastic succession as the product of south-flowing braided streams that were separated by low-lying swamp and lacustrine settings. High-angle faults bound units Tcl and uTcf (Dickey 1982).

Ridgway and others (2000) measured nearly $500 \mathrm{~m}$ of conglomerate, sandstone, and mudstone exposed along ridgetops immediately south of the Farewell fault near the White Mountain mine (part of the Cretaceous (?) section described by Sainsbury and MacKevett, 1965) (Fig. 1). These exposures are part of the fill of what Ridgway and others (2000) refer to as the White Mountain basin. Three lithofacies were recognized, 
including granule and pebble conglomerate; massive and trough cross-stratified sandstone; and mudstone. These lithofacies represent the product of low-sinuosity streams and adjacent overbank areas (Ridgway and others, 2000). Paleocurrent data suggest streams entered the basin from the east and flowed westward along the basin axis (Ridgway and others, 2000).

\section{Regional Tectonic Setting}

The Holitna basin and exposures of coal-bearing Tertiary rocks along the Alaska Range front to the northeast are intimately related to the DFS. The DFS is one of the most conspicuous geologic features in southern Alaska, where it extends in a broad arc for nearly 1,600 $\mathrm{km}$ from the Bristol Bay region on the west to the Alaska-Yukon border on the east (Plafker and others, 1977). Grantz (1966) divided the Denali fault system into three segments based, in part, on the contrasting orientation of fault structures. The eastern segment, referred to as the Shakwak valley segment, trends northwest; the western segment, referred to as the Farewell segment, trends northeast and cuts through the Holitna basin and exposures of Tertiary strata to the northeast (described below). The eastern and western segments are connected by a central segment that consists of two northward convex faults - the Hines Creek and Denali faults. Richter and Jones (1973) suggested that the Denali fault system formed along a late Paleozoic continental suture that was transformed to a strike-slip fault system in Tertiary time as a consequence of a change in plate motions. Most workers agree that the DFS is a major crustal scale tectonic feature that was significant in the tectonic evolution of southern Alaska (Grantz, 1966; Lanphere, 1978; Nokleberg and others, 1985; Plafker and others, 1977; Plafker and others, 1989; see Csejtey and others, 1996, for an opposing view).

The Farewell segment (synonymous with Farewell fault zone) is the least known stretch of the DFS (Lanphere, 1978). Grantz (1966) noted the segment is a complex feature characterized by many fault strands. Grantz (1966) also noted a dip-slip component along the fault segment (up on the south) and right-lateral separation based on offset Cretaceous rocks along the western end of the segment and regional drag features in rocks south of the fault. Offset Paleozoic facies trends along the west end of the segment suggest over $100 \mathrm{~km}$ (60 miles) of right-lateral offset (Decker and others, 1994). Although the sense of motion appears well established, not all workers agree. Redfield 
and Fitzgerald (1993) question right-lateral motion along the western part of the DFS and argue for left-lateral motion on kinematic grounds.

The present distribution of Tertiary strata in outcrop is controlled by movement along the Farewell segment of the DFS. Similarly, the origin of the Tertiary section is most likely tied to the history of the Farewell fault zone. Discontinuous exposures of Tertiary strata have been described in close proximity to the Denali fault system along much of its length (Hickman, 1974; Hickman and others, 1977, 1978; Hickman and others, 1990; Reed and Nelson, 1980; Ridgway, 1992; Ridgway and others, 1997; Stout, cited in the DGGS 1973 Annual Report; Wahrhaftig and others, 1969; Wahrhaftig, 1987), presumably reflecting deposition in areally restricted strike-slip basins. Most other major strike-slip fault systems around the world have associated sedimentary basins (Reading, 1980; Christie-Blick and Biddle, 1985).

\section{BASIN ANALYSIS APPROACH}

The goal of this project is to evaluate the shallow gas potential of the Holitna basin. At least three theoretical plays exist in the basin. Carbonaceous mudstones and coal represent potential source rocks for all three plays. The first play involves gas stored in sandstone and conglomerate reservoirs and is referred to as the conventional gas play. The second play involves gas stored in carbonaceous mudstone and coal beds and is referred to as the coalbed methane play. The third play involves liquid hydrocarbons stored in sandstone and conglomerate reservoirs and is referred to as the conventional oil play.

Our basin analysis approach involves utilization of potential field geophysics and studies of Tertiary strata exposed in the southern and central McGrath Quadrangle northeast of the Holitna basin (Fig. 1). DGGS contracted Dr. John Cady to reprocess and interpret a high-resolution aeromagnetic survey of the Holitna lowland region flown in 1997. In addition, DGGS purchased a regional gravity survey of the Holitna lowland region that was acquired in 1982 by Edcon, Inc. of Denver, Colorado. Dr. Cady is interpreting the gravity data and integrating both datasets for a comprehensive geophysical interpretation of the Holitna basin. Exposures of Tertiary strata in the McGrath Quadrangle are critical as they represent the closest exposures of rocks thought to be similar to the sedimentary fill of the Holitna basin. Our studies of Tertiary strata in outcrop in the McGrath and northeastern Talkeetna quadrangles focused on 1) evaluating 
the stratigraphy (including biostratigraphy) and depositional environments; 2) evaluating the reservoir potential of sandstones and conglomerates; and 3) evaluating the source rock potential of coals and carbonaceous shales.

\section{STRATIGRAPHY AND DEPOSITIONAL ENVIRONMENTS}

The descriptions and interpretations that follow are based on 10 days of helicopter-supported field work on exposures of Tertiary coal-bearing strata from the lower Cheeneetnuk River (Lime Hills D-6 and D-7 quadrangles) to the Little Tonzona River (Talkeetna C-6 quadrangle) in late July 2000. Our work builds on published mapping and stratigraphic studies of the Tertiary section in outcrop. The purpose of our work was to better understand the stratigraphy and sedimentology of the Tertiary section, with particular emphasis on the nature of potential reservoir and source rocks.

Stratigraphic sections were examined in detail at White Mountain, Middle Fork of the Kuskokwim River, Khuchaynik Creek, Windy Fork of the Kuskokwim River, and Little Tonzona River; measured sections through selected intervals were obtained at all locations except White Mountain (see Ridgway and others, 2000, for a measured section). Extremely limited exposures of the Tertiary section along the lower Cheeneetnuk River did not warrant measurement. Preliminary descriptions of each location are presented below, along with brief interpretations of the depositional environments. The White Mountain section is summarized in Ridgway (2000) and is not discussed in detail in this report. Correlation of the Tertiary section in the McGrath Quadrangle with other Tertiary exposures in central and southern Alaska are summarized in Fig. 3.

In the discussion that follows, all plant megafossil identifications were done by the second author (Blodgett), with the exception of a single collection from the Cheeneetnuk River, identified by the late Dr. Daniel Axelrod (formerly at the University of California, Davis). All plant microfossils were identified, and abundance data quantified, by Dr. Robert Ravn (consultant under contract to DGGS, Aeon LLC., Anchorage, Alaska). Age calls and climatological analysis based on Ravn's data were performed by Dr. Pierre Zippi (consultant under contract to DGGS, biostratigraphy.com, Garland, Texas). Reports from these contractors will be released to the public as DGGS interpretive reports. 


\section{Cheeneetnuk River}

Gilbert (1981) mapped two small exposures of Tertiary strata (unit uTs) along the Cheeneetnuk River between $155^{\circ} 15^{\prime}$ and $155^{\circ} 11^{\prime}$ west longitude (Fig. 4). Exposure quality and continuity are extremely poor and stratigraphic sections could not be measured at either location.

\section{Biostratigraphy}

Small broken broadleaf plant fossils were common in the float. Plant megafossils collected from this outcrop were analyzed by the late Dr. Daniel Axelrod (University of California, Davis), who assigned a tentative late Miocene age to the collection based the presence of poorly preserved Salix, Platanus, and Alnus specimens and comparison with a similar age flora from western Oregon (written comm.. to Blodgett, 1980). Palynologic samples yielded two age diagnostic taxa, Diervilla echinata and Tsuga heterophylla (Ravn, written comm., 2001), indicative of a rather broad age range from middle Miocene to late Eocene (Zippi, written comm., 2001). However, Zippi (written comm., 2001) considered these rocks to be equivalent to the Homerian stage based on the nearly equal abundance of cold and temperate climate taxa and the near absence of taxa that prefer warm climates. Zippi's Homerian correlation is in agreement with Axelrod's late Miocene age assignment.

\section{Stratigraphy and Lithofacies}

The northeasternmost location (station 00DL30) consists of a 2-m-high bluff with small, discontinuous exposures of orange-brown weathering siltstones that appear to be in place. The southernmost location (station 00DL57) consists of siltstone float and small fragments of bright coal scattered among the riverbank vegetation. Float was scarce at this location and uncertainties regarding the source of the material precluded collecting samples.

Bundtzen and Kline (1986) reported coal-bearing Tertiary rocks overlying Devonian limestone in the vicinity of 00DL30 and reported "brittle coal beds up to $0.5 \mathrm{~m}$ known thickness." They also reported high sulfur contents in two samples (as much as 8.19 weight percent). 


\section{Interpretation}

Little can be said about these exposures, other than the siltstone and poorly preserved plant megafossils suggest periodic incursions of silt laden waters in a flood basin setting distal to active stream channels. Bright coal at location 00DL30 indicates at least local accumulation and preservation of terrestrial vegetation. This interpretation agrees with Zippi (written comm., 2001), who stated "The presence of dinoflagellates and green algae along with abundant conifer pollen indicate deposition in a fluvial system with standing water, such as a swamp, slough, or small lake. The pollen flora is dominated by mixed conifer forest taxa Picea, Pinus and Tsuga with very low proportions of spores and angiosperm trees, shrubs, and grasses."

\section{White Mountain}

Tertiary strata south of White Mountain (Gilbert's map unit Tcg; station 00DL56 on Fig. 5) are situated in a down-dropped fault block bounded on the north side by the Farewell fault (Sainsbury and MacKevett, 1965) and an unnamed fault on the south side (Gilbert, 1981). Bedding dips toward the east and southeast at moderate angles. These bounding high-angle faults juxtapose the Tertiary section against Paleozoic shallowwater strata of the Nixon Fork terrane (north of Farewell fault) and Paleozoic deep-water strata of the Dillinger terrane (south of unnamed fault). Owing to poor exposure quality and the presence of only small, very poorly preserved plant megafossils, paleontologic samples were not collected during our study.

Several north-trending resistant units with intervening recessive weathering intervals are clearly visible from the air (Fig. 6). The resistant units range from $10 \mathrm{~m}$ to over $50 \mathrm{~m}$ thick; intervening mudstones range from a few meters thick to nearly $40 \mathrm{~m}$ thick (Ridgway, 2000). In general, the organization is similar to the lower two-thirds of the sections exposed on the Middle and Windy forks of the Kuskokwim River, which are described below. Intervening mudrocks at White Mountain, although poorly exposed, appear to include much less organic material and little or no coal. Ridgway's (2000) section represents less than a quarter of the thickness that Sainsbury and MacKevett estimate is present in the area. We agree with Ridgway's (2000) interpretation of the succession as the product of low-sinuosity braided streams with associated overbank deposits. Alternating resistant and non-resistant units (coarse-grained and fine-grained 
lithologies, respectively), manifested in outcrop by alternating ridges and swales (Fig. 6), may be the result of episodic faulting along the Farewell fault zone.

\section{Middle Fork and Windy Fork}

East of White Mountain, the Tertiary section disappears under a veneer of Pleistocene glacial outwash and Holocene alluvium and does not reappear until a few kilometers east of the Big River, where rubble of Tertiary strata covers hilltop areas. Relatively good exposures of Tertiary strata are present along the Middle and Windy forks of the Kuskokwim River (Figs. 1, 7a, and 7b). These exposures were mapped by Dickey (1982; his unit Tqa). The succession in both exposures (Dickey's (1982) unit Tqa) is similar, consequently, they are discussed together in this section. Measured sections through portions of both exposures are shown in Figures 8 and 9.

Exposures continue for nearly $2.5 \mathrm{~km}$ along the east and west banks of the Middle Fork and for a comparable distance along the west bank of the Windy Fork. Dickey (1982) measured nearly $650 \mathrm{~m}$ and 1,850 $\mathrm{m}$ of Tertiary strata along the Middle and Windy forks, respectively, but was unable to measure complete thicknesses along both drainages due to structural complications and limited accessibility. High-angle faults of unknown displacement truncate the base of both exposures and numerous smaller scale high-angle faults are present within the Tertiary section along both drainages. Further complicating estimates of stratigraphic thickness is the presence of a map-scale syncline near the north end of the Windy Fork exposure. The amount of section removed by faulting at both locations is unknown.

\section{Biostratigraphy}

Plant megafossils and microfossils obtained from the Middle Fork and Windy Fork sections help constrain their age. Plant megafossils from the middle Fork section include indeterminate betulaceans and Alnus sp., indicating a broad Oligocene to Recent age range. Megafossils from the Windy Fork section include Metasequoia cf. glyptostroboides Hu and Cheng, Alnus sp., Carpinus seldoviana Wolfe, Salix cappsensis Wolfe, and Ulmus knowtoni Tanai and Wolfe. This flora suggests correlation with the Seldovian stage from the Cook Inlet region and an early to middle Miocene age. Similarities in the stratigraphic organization of both sections suggest a middle Miocene age for the Middle Fork section. 
Palynologic samples from the Middle Fork section yielded Corsinipollenites oculusnoctis, Diervilla echinata, and Tsuga heterophylla (Ravn, written comm., 2001), which indicate a middle Miocene to late-middle Eocene age (Zippi, written comm., 2001). The Windy Fork palynoflora includes Diervilla echinata, Tilia crassipites, and Tsuga heterophylla (Ravn, written comm., 2001), which suggest a middle Miocene to late Eocene age (Zippi, written comm., 2001).

Taken together, the megafossil and microfossil taxa suggest an early to middle Miocene age and correlation with the Seldovian floristic stage of Wolfe and others (1966) and Wolfe and Tanai (1980). We consider the strata exposed along Middle Fork and the west bank of Windy Fork to be roughly correlative.

A sample collected from the east bank of Windy Fork (station 00DL58 on Fig.7b, located roughly along strike from the northernmost exposures on the west bank (station 00DL34 on Fig.7b), included two specimens of the spore Aquilapollenites, which occurred from Late Cretaceous through Oligocene. While it is possible these spores were reworked from older rocks (Ravn, 2001), it is equally possible that they are in situ (Zippi, 2001). If the latter is correct, the age of this part of the exposure is restricted to Oligocene to late Eocene. If correct, a fault likely separates exposures on the east and west banks.

\section{Stratigraphy and Lithofacies}

Description - Assuming no major faults within the Tertiary sections at Middle Fork and along the west bank of Windy Fork, both sections are characterized by an overall fining-upward trend from pebble and cobble conglomerates near the base to interbedded siltstone, silty claystone, and coal near the top. The fine-grained lithologies are commonly carbonaceous and coals are typically high in ash content. The basal (southern) two-thirds to three-quarters of both exposures consists of numerous resistant weathering bodies of conglomerate, pebbly sandstone, sandstone, and minor mudstone from $3 \mathrm{~m}$ to $25 \mathrm{~m}$ thick, separated by recessive weathering mudstone intervals from a few meters to over $80 \mathrm{~m}$ thick (Fig. 10a).

Massive pebble and cobble conglomerates account for over 50 percent of the coarse-grained bodies at both locations (Figs. 8a, 9a, and 9b). Sandstone comprises approximately 35 percent. Conglomerate beds are a few decimeters to over $3 \mathrm{~m}$ thick and are commonly amalgamated to form thicker composite bodies (Fig. 10b). Conglomerate 
beds are typically lenticular (Fig. 10c), but many outcrops have insufficient lateral extent to evaluate bedding geometry. Concave-upward erosional surfaces with up to $2 \mathrm{~m}$ of relief are common and may separate individual channel and bar macroforms (Fig. 10c).

Conglomerates are clast-supported, polymictic, and characterized by coarsegrained sandstone to granule conglomerate matrix. The matrix material creates a distinctive bimodal to polymodal texture. Most conglomerate beds display massive internal fabrics or poorly defined horizontal stratification; clast imbrication is welldeveloped locally, particularly where conglomerates include a high proportion of discshaped clasts. Clasts of vein quartz, black chert to dark gray chert, and black to dark gray argillite are abundant, and clasts of felsite are common. Coal clasts are present in conglomerates in both section, but are not abundant.

Dickey $(1982,1984)$ reported paleocurrent data from conglomerates that suggested south-flowing currents. We measured both south and north paleoflow indicators (from clast imbrication), suggesting a more complicated sediment dispersal pattern.

Laterally continuous pebbly sandstone and sandstone beds cap conglomerate beds locally (Fig. 9a). Sandstones form bedsets up to $2 \mathrm{~m}$ thick that are commonly transitional into overlying mudstone successions (Fig. 10d). Sandstone lenses up to $1 \mathrm{~m}$ thick within conglomerate bodies are common (Figs. 10f and 10g). Where mudstone overlies sandstone, the latter lithology becomes progressively muddier upsection and includes abundant variably preserved plant megafossils on bed parting surfaces. Casts of tree trunks and logs are relatively common in both conglomerates and sandstones (Fig. 10h). Minor mudstones up to $2 \mathrm{~m}$ thick are present as lenses within these coarser-grained bodies. Plant leaf impressions and coalified plant material are common in mudstone lenses.

Siltstone and silty shale successions up to $25 \mathrm{~m}$ thick separate conglomerate and sandstone bodies in the lower two-thirds to three-quarters of both the Middle Fork and Windy Fork successions (Figs. 8a, 9b, 10a, and 10i). These finer-grained lithologies are typically recessive weathering and exposures are poor to absent. Where exposed, the succession consists of silty shale, siltstone, bituminous coal, and minor sandstone and conglomerate (Fig. 10j). Silty shale and siltstone are locally carbonaceous and the latter lithology commonly includes abundant well-preserved plant megafossils (broadleaf impressions). Coals range from a few millimeters to several centimeters thick and many 
are laterally continuous in outcrop. Coals are characterized by low sulfur content and some are more appropriately classified as carbonaceous shales or carbonaceous mudstones (Table 1). Coals with lower ash contents have alternating bright and dull bands up to two millimeters thick. Small non-descript gastropods and unornamented bivalves were noted in one mudstone succession on the Middle Fork (Fig. 8a).

Sandstone bodies up to $2 \mathrm{~m}$ thick are present in some mudstone successions (Fig. 10k). Conglomerates are present only locally in these bodies, are less than $40 \mathrm{~cm}$ thick, and are usually situated at the base of sandstone bedsets. Most conglomerates are massive, but some fine-upward and grade into overlying sandstones. Sandstones are medium- to coarse-grained, pebbly, and medium-bedded. Many sandstone beds are massive, but trough cross bedding is present locally. The basal contacts between these lithologies and the underlying mudstones are sharp; upper contacts are typically gradational and characterized by thinly interbedded sandstone and mudstone, with the proportion of mudstone increasing steadily upsection. Mudstone ripups are present locally near basal contacts with mudstones.

The upper one-third to one-quarter of the Tertiary section along both drainages consists of up to several hundred meters of silty shale, carbonaceous silty shale, coal, and minor sandstone and conglomerate (Figs. 8b, 9c, and 101). Of these lithologies, silty shale and carbonaceous silty shale account for approximately 70 percent of the stratigraphic thickness. Silty shales typically weather into small chips and irregular shaped small blocks, but locally display a fissile weathering character. Coal is common (up to 5 percent of the total succession) throughout this part of the succession and is present in millimeter-thick stringers and, less commonly, as seams up to $0.5 \mathrm{~m}$ thick. Most coals have alternating bright and dark bands, and have low sulfur and moderate to high ash contents (Table 1). Sandstone and conglomerate beds are present in finingupward (Fig. 10m) and coarsening-upward (Fig. 10n) successions up to $3 \mathrm{~m}$ thick. In fining-upward successions, sandstones and conglomerates are situated above sharp, erosional basal contacts with mudstone and are gradationally overlain by siltstone. Fining-upward successions are similar to those noted in the lower two-thirds of both exposures. Coarsening-upward successions start with silty claystones and grade upsection to siltstones and sandstones. Coarsening-upward successions like these were not observed in the lower two-thirds to three-quarters of the Tertiary section at both locations. 
Interpretation - Massive clast-supported conglomerates with poorly sorted sandstone as matrix and tree stump and log casts, suggest deposition from flood events in a non-marine setting - possibly from hyperconcentrated flows (Pierson and Costa, 1987). Conglomerates with imbricate clast fabrics suggest transport and deposition from traction currents in confined channels, possibly during the early waning stages of fluvial flood events. Sandstone lenses record deposition during the later waning stages of flood events, or in the lee gravel macroforms under normal flow conditions. Sandstone bedsets transitional between conglomerate below and mudstone successions above record gradual abandonment of fluvial channel tracts, whereas conglomerate packages abruptly overlain by mudstones likely record major channel avulsion events. Mudstone successions between conglomerate bodies record deposition in perennial flood basins adjacent to active fluvial channel tracts. Sandstone and conglomerate bedsets within these mudstones record episodic major fluvial flood events and deposition as crevasse splays derived from nearby active channel tracts.

The thick mudstone successions at the north end of both sections probably record deposition in a long-lived lacustrine or perennial swamp setting. The abundance of terrestrial plant material indicates thickly vegetated areas within the swamp setting. Thin coal seams may have originated as allochthonous peak mats or in areally restricted, relatively short-lived mires scattered along the perimeter of a lake or throughout a swamp setting. Abundant ash in most coal seams indicates deposition near active fluvial channel tracts. High ash coals are consistent with deposition in relative proximity to active fluvial channel tracts. Fining-upward successions of sandstone and conglomerate are similar to those present in the lower parts of both sections and likely have a similar origin as crevasse splay deposits or high-sinuosity channel-point bar successions. Alternatively, some fining-upward successions, such as the one shown in Fig. 10m, may represent point bar sequences deposited by high-sinuosity streams. Coarsening-upward successions probably represent small lacustrine deltas.

\section{Khuchaynik Creek}

Two distinctly different successions are exposed in separate fault blocks on the west side of the Khuchaynik Creek (Fig. 7b). Dickey (1982) mapped a southern fault block (his Tcl unit) dominated by limestone conglomerates and a northern fault block (his Tqa unit) containing a heterolithic succession of conglomerate, sandstone, siltstone, and 
shale (Fig. 11). Conglomerates in unit Tqa include a variety of clast compositions, of which limestone is a minor component.

\section{Biostratigraphy}

Poorly preserved specimens of the plant megafossil Metasequoia $\mathrm{cf}$. glyptostroboides $\mathrm{Hu}$ and Cheng suggest an undifferentiated Miocene age for unit Tcl. The palynoflora recovered from unit Tcl includes Diervilla echinata and Tsuga heterophylla (Ravn, written comm., 2001), which suggests a middle Miocene to late Eocene age (Zippi, written comm., 2001). Plant megafossils recovered from siltstones of unit Tqa include Metasequoia cf. glyptostroboides Hu and Cheng, Salix cappsensis Wolf, Salix? spp., Carpinus? n sp., and Acer ezoanum Oishi and Huzioka, which suggest an early to middle Miocene age. The palynoflora recovered from unit Tqa include Diervilla echinata and Tsuga heterophylla (Ravn, written comm., 2001), which suggest a middle Miocene to late Eocene age (Zippi, written comm., 2001). Collectively, the macrofossil and microfossil taxa collected from unit Tqa suggest correlation with the Seldovian floral stage (late Oligocene to middle Miocene) of Wolfe and others (1966) and Wolfe and Tanai (1980).

\section{Stratigraphy and Lithofacies}

Description - Unit Tcl consists largely of steeply dipping (near vertical) green weathering, clast-supported conglomerate (Fig. 12a). Bed thickness ranges from $0.5 \mathrm{~m}$ to approximately $1.5 \mathrm{~m}$. As stated above, gray limestone clasts are most abundant, but chert, vein quartz, and volcanic rock fragments are also represented. Limestone clasts look similar to lithologies recognized in the Dillinger sequence. Equant and disc-shaped clasts are common, but the latter appear to be more common. Equant clasts tend to be larger (up to $22 \mathrm{~cm}$ ) and segregated into beds where they represent the dominant clast morphology (Fig. 12b). Where disc-shaped clasts are abundant, a pronounced low-angle imbricate fabric is present (Fig. 12b). Matrix material fills most void spaces between clasts in conglomerate beds, is greenish colored, and consists of poorly sorted sandstone and granule conglomerate. Minor lenses of sandstone and siltstone up to a $0.5 \mathrm{~m}$ thick are present between some conglomerate beds. Siltstones include scrappy plant leaf impressions (Metasequoia). 
Unit Tqa is very similar to the southern two-thirds to three-quarters of the Middle Fork and Windy Fork sections. The thick mudstone succession capping both the Middle and Windy fork successions is either not present or not exposed along the Khuchaynik River. The succession consists of composite conglomerate and sandstone bodies up to 15 $\mathrm{m}$ thick separated by poorly exposed mudstone intervals up to $22 \mathrm{~m}$ thick. Conglomerates are clast-supported, polymictic, and include both pebble- and cobblesized clasts. Conglomerates are commonly internally massive, but poorly developed horizontal stratification is also common; bed thickness ranges from one meter to $11 \mathrm{~m}$. Some of the thicker conglomerate beds may contain cryptic amalgamation surfaces (Fig. 12d). Sandstones are commonly medium- to very coarse-grained and pebbly. Bedding ranges from a few decimeters to over $0.5 \mathrm{~m}$ thick and is usually devoid of visible sedimentary structures. Trough cross bedded sandstone is rare. Sandstones are present as thin lenses between conglomerate beds and as laterally continuous beds, at least at outcrop scale, capping conglomerate bodies. Most conglomerates have a sheet-like geometry at outcrop scale, but high-angle channel margins (or scour margins) are present locally. Mudstones in unit Tqa are very poorly exposed and appear to consist of siltstones. One notable difference between the Khuchaynik River and Windy/Middle Fork sections is the apparent absence of coal and carbonaceous mudstones in the former section.

Interpretation - Unit Tcl was derived from a source terrane dominated by carbonate rocks. Many limestone clasts examined in the field appear similar to carbonate lithologies present nearby in the Dillinger sequence. The abundance of spore pollen and presence of plant megafossils indicated deposition in a non-marine setting. Imbrication of platy clasts and segregation of larger equant clast shapes suggest conglomerates in unit Tcl record transport and deposition from traction currents during flood events. Lateral continuity of exposure in unit $\mathrm{Tcl}$ is extremely limited and inferences regarding conglomerate body geometry cannot be made. Minor siltstone and sandstone lenses likely record deposition during the waning stages of flood events.

Unit Tqa is similar to the Tertiary successions exposed along the Middle and Windy forks of the Kuskokwim River and is similarly interpreted. The apparent absence of coal and carbonaceous mudstone may be due to non-deposition or structural removal (faulted out). 


\section{Little Tonzona River}

Approximately $50 \mathrm{~m}$ of coal-bearing Tertiary strata are exposed on the west bank of the Little Tonzona River in the northwestern corner of the Talkeetna Quadrangle (Player, 1977) (Figs. 13 and 14a). The lateral continuity of these exposures is extremely limited and no exposures of Tertiary sedimentary rocks have been recognized on the east side of the Little Tonzona River.

\section{Biostratigraphy}

No plant megafossils worth collecting were encountered at the Little Tonzona exposure, however, four palynologic samples were collected from silty claystones between coal seams. Palynoflora include Boisduvalia clavatites, Tilia crassipites, Diervilla echinata, Tsuga diversifolia, and Tsuga heterophylla (Ravn, written comm., 2001). According to Zippi (written comm., 2001), the age of these rocks "is restricted to the Oligocene (probably early Oligocene) by the presence of Boisduvalia clavatites. The occurrence of Tilia crassipites also suggests an Oligocene age....."

\section{Stratigraphy and Lithofacies}

Description - The succession exposed at the Little Tonzona River is unlike anything else in the outcrop belt (Figs. 13 and 14). Coals are dark brown lignite and resemble delaminated plywood. Seams dip $60^{\circ}$ to $70^{\circ}$ toward the north-northwest, and account for over 60 percent $(31 \mathrm{~m})$ of the exposed thickness (Fig. 15). Individual seams are up to $9 \mathrm{~m}$ thick. Silty claystones up to $4 \mathrm{~m}$ thick split the exposure into at least eight discrete coal seams. The ash content is low and sulfur content ranges from 1.04 to 2.25 weight percent (mean 1.79; Table 1). Bundtzen and Kline (1986) reported that sulfur content varies considerably from bed to bed in the Little Tonzona River coals. Plant fragments in the mudrocks are small, poorly preserved, and not abundant. Amber is abundant in most coal seams as fractured masses up to $1.5 \mathrm{~cm}$ in diameter. At least two tephra beds nearly completely altered to bentonite are present. The lower tephra, at least $1 \mathrm{~m}$ thick, was sampled for Ar/Ar dating, but no datable material was recovered. These are the only ash beds recognized in the Tertiary section between the lower Cheeneetnuk and Little Tonzona rivers.

Interpretation - Thick low-ash coals at the Little Tonzona River location indicate deposition in a long-lived swamp setting removed from sources of siliciclastic sediment 
input - probably in a raised mire environment (McCabe, 1984). The abundance of amber indicates conifer trees were abundant, which is consistent with a palynoflora dominated by Picea, Pinus, and Tsuga (Zippi, written comm., 2001). Thick altered tephra deposits indicate volcanic activity somewhere in the region, presumably to the south. Interbedded silty mudstones suggest periodic inundation of the mire environment, possibly due to episodic tectonic activity (fault-related subsidence?). The absence of siliciclastic interbeds coarser than silty claystone indicates this part of the mire environment was removed from active fluvial channel tracts throughout its depositional history. The lateral extent of the mire is unknown (see interpretation of Deepbank Creek location below). Our interpretation is consistent with Zippi's, who stated "The presence of dinoflagellates and green algae along with abundant forest tree pollen indicate deposition in forested fluvial system with standing water, such as a swamp, slough, or small lakes."

The sulfur content of the Little Tonzona coals is two to five times higher than coal exposed at Deepbank Creek $7 \mathrm{~km}$ southwest the Little Tonzona locality (Fig. 13).

\section{Deepbank Creek}

A small exposure of coal is present in the bank of a tributary to Deepbank Creek, approximately $7 \mathrm{~km}$ west-southwest of the Little Tonzona River exposure (Figs. 13, location 00DL43, and 15b).

Description - The coals here are virtually identical to the Little Tonzona coals in appearance. An extremely limited sample suite (two samples) suggests ash contents between 8 and 20 percent and sulfur contents between 0.4 and 0.8 weight percent. Notably, the sulfur is lower than in the Little Tonzona River coals. No other lithologies are exposed at this location. No biostratigraphic data are available for this exposure.

Rubblecrops (loose blocks and chips of rock, essentially in place and in correct stratigraphic position, but detached from solid outcrops) of bright orange-red weathering baked siltstone (clinker), minor altered tephra, and sandstone are present along a low northeast-trending ridge situated mid-way between the Little Tonzona and Deepbank locations (Figs. 13 and 15c). The bright orange-red coloration is due to prolonged heating, most likely from burning coal at depth. The presence of these beds suggest that coal extends continuously from the Little Tonzona River at least as far west as Deepbank Creek. No exposures of Tertiary strata were observed between Deepbank Creek and the Windy Fork. The presence of the plant megafossil Carpinus seldoviana Wolfe in baked 
siltstones suggests an early to middle Miocene age for the clinker beds and correlation with the Seldovian floristic stage in the Cook Inlet area (Wolfe and others, 1966; Wolfe and Tanai, 1980).

Interpretation - Coal at Deepbank Creek is virtually identical to the Little Tonzona River coal in appearance but not sulfur content (Table 2). In spite of differing sulfur contents, we tentatively correlate the Deepbank Creek coal with the Little Tonzona River coal and interpret the depositional setting similarly as the product of deposition in a raised mire.

\section{STRATIGRAPHIC TRENDS}

The relation between the Tertiary section in outcrop and the fill of the Holitna basin remains speculative. Detailed regional gravity data (DGGS Geophysical Report 2001-1) show a northeast-elongate low that extends from approximately $157^{\circ} 27^{\prime}$ west longitude (a few kilometers west of the village of Sleetmute) to approximately $155^{\circ} 30^{\prime}$ west longitude (lower reaches of the Cheeneetnuk River) in the northwestern Lime Hills

Quadrangle. The magnitude of the gravity low decreases progressively toward the northeast, indicating the presence of a pre-Tertiary basement high (or sill) separating the outcrop belt from the Holitna basin.

Smith and others (1985) interpret up to 4,500 m (nearly 14,600 feet) of Tertiary strata in the Holitna basin based on a coarse grid of gravity data, and at least 1,800 $\mathrm{m}$ of Oligocene to Miocene age section is present in outcrop northeast of the basin. As stated previously, the section in outcrop is broken into several fault-bounded slivers; each sliver is bounded by high-angle faults precluding estimations of the original depositional thickness of the Tertiary section.

The thickest coal section is present at the Little Tonzona River and the thickest carbonaceous mudstones are present along the Middle and Windy forks of the Kuskokwim River. Coal and carbonaceous mudstone are absent in exposures near White Mountain and only small exposures of mudstone with thin coaly stringers are present farther to the southwest, along the Cheeneetnuk River.

The relation, if any, between coal-bearing strata on the Little Tonzona River and the latter locations is unknown. Biostratigraphic data suggest that strata on the Little Tonzona River are older (early Oligocene) and were probably deposited in a depositional system unrelated to those responsible for the Windy Fork and Middle Fork successions. 
Biostratigraphic data also suggest that Tertiary strata become progressively younger toward the southwest as indicated by the likely presence of Homerian (middle to late Miocene) strata on the lower Cheeneetnuk River. It is unknown whether the present day outcrop belt represents the exhumed fill of a single depositional basin or several depositional basins (Bundtzen and Kline, 1986).

\section{SHALLOW GAS POTENTIAL}

This section summarizes stratigraphic features and geochemical data of significance in assessing the shallow gas potential of the Tertiary Holitna basin. Reservoir and trap potential are discussed first utilizing information presented in the previous sections. Source rock potential is discussed using data gathered in this study and previously published sources. The shallow gas potential is summarized at the end of the section.

\section{Reservoir and Trap Potential}

Conglomerate and sandstone bodies similar to those exposed at White Mountain and between the Middle and Windy forks of the Kuskokwim River could form hydrocarbon reservoirs if present in trapping configurations in the subsurface of the Holitna basin with sufficient effective porosity. Conglomerates in outcrop have an apparent sheetlike geometry, but quantitative information on the lateral extent of conglomerate bodies is unavailable owing to the limited extent of most outcrops. Conglomerates are clast-supported and include poorly sorted sandstone and granule conglomerate as matrix between the larger clasts. Clast compositions are dominated by metamorphic rock fragments, vein quartz, and locally important felsic volcanic and limestone fragments (Dickey, 1982). Most clasts are likely to have near-zero porosity and permeability. The poorly sorted material between clasts can be expected to have low porosity and permeability.

Sandstones are common in all exposures west of Deepbank Creek, but are less abundant than conglomerates. Most sandstones examined comprise bedsets up to a few meters thick that are interbedded with conglomerate and mudstone. Thick sandy successions appear to be lacking. Sandstone composition is dominated by metamorphic rock fragments including schist, argillite, and quartz. As with the conglomerates, sandstones with felsic volcanic and limestone grains are locally important. Most 
sandstones are tightly cemented, exhibit little visible indication of porosity, and appear to have low reservoir potential.

Bed dips in most exposures are moderate to steep and no outcrop examples of structural closures were noted. Most exposures are cut by minor faults and exposure boundaries are usually defined by major high-angle faults. The degree of faulting observed in outcrop suggests reservoir geometries would be complex and reservoir units would have low lateral continuity.

Lithologies capable of forming reservoir topseals are present in outcrop, but are not volumetrically abundant or aerially widespread. Most fine-grained rocks in the Tertiary section are silty and at shallow burial depths (less than 2,000 m), at best, would probably form leaky reservoir topseals.

These observations suggest that reservoirs would be structurally complicated, highly compartmentalized, laterally discontinuous, and leaky. The presence of alternating successions of conglomerate and mudstone suggest that stratigraphic traps may be present if thick conglomerate bodies pinchout in mudstones. However, the same observation regarding topseal integrity applies. Overall, the reservoir potential of conglomerates and sandstone is probably poor to fair, which increases the risk associated with the first of the two plays identified above.

\section{Source Rock Potential of Tertiary Strata in Outcrop}

The abundance of carbonaceous mudstone and coal in outcrop in the McGrath Quadrangle suggests that they represent the primary potential source rocks in the Tertiary Holitna basin. Terrestrial organic material is most commonly gas-prone; however, lacustrine shales enriched in algal material can be excellent source rocks for liquid hydrocarbons (Tissot and Welte, 1984). To assess their potential, DGGS collected samples of carbonaceous mudstones and coal for laboratory analysis. Analytical tests included standard coal quality tests (proximate and ultimate), coal petrology, high pressure methane adsorption, Rock-Eval pyrolysis, kerogen microscopy, and whole extract gas chromatography. Our coal quality and vitrinite reflectance data add to the database of publicly available information for these rocks (Sloan, 1979; Solie and Dickey, 1982). To our knowledge no coal petrology, high-pressure methane adsorption, or organic geochemistry data have been published. This section summarizes DGGS geochemical data from samples collected by DGGS. Vitrinite reflectance determinations 
from coal petrology and kerogen microscopy are discussed at the end of this section. Results from whole extract chromatography are included in the appendix and are not discussed below. The sample suites subjected to these various analyses was small and we are not certain how representative they are of source rock potential over the wider area.

\section{Coal Quality}

Twenty two samples were submitted to Geochemical Testing in Somerset, PA, for proximate and ultimate analyses. The data are summarized in Table 1 and sample collection sites are shown in Figures $2 \mathrm{~b}$ and $2 \mathrm{c}$. Most of the samples contained high ash contents (greater than 8 percent), and many samples are high ash coals or carbonaceous mudstones. Most coal samples collected from the thick lacustrine and swamp successions along Middle and Windy Forks have high ash contents. The ash content of coal exposed at the Little Tonzona River and Deepbank Creek localities are much lower (less than 21 percent), on average, than elsewhere in the outcrop belt. The sulfur content of most samples ranges from 0.02 to 0.75 weight percent. Coals at the Little Tonzona River have sulfur concentrations between 1.04 and 2.25 weight percent, significantly higher than others locations represented in our sample suite. Solie and Dickey (1982) report high sulfur contents (up to $8.19 \%$ by weight) in coal samples from exposures along the Cheeneetnuk River southwest of White Mountain. Coal quality data from our study are available from DGGS (Raw Data-file 2002-xx, in press). Additional coal quality data are presented in Player (1976) and Solie and Dickey (1982).

\section{Coal Petrology}

Thirteen coal and carbonaceous mudstone samples were submitted to R.M.B. Earth Science Consultants in British Columbia, Canada, for petrographic analysis. Many samples include abundant mineral material and are classified as high-ash coal or carbonaceous mudstone. All samples consist predominantly of vitrinite group macerals (about 90 percent) with minor amounts of inertinite (less than 2 percent) and trace amounts of liptinite. Microlithotype bands vary from a few micrometers to tens of micrometers and are interbanded with claystone. Coal petrology data from our study are available from DGGS (Raw Data-file 2002-xx, in press). 


\section{High Pressure Methane Adsorption}

Six samples were analyzed by R.M.B. Earth Science Consultants in British Columbia, Canada, for high-pressure methane adsorption isotherms. All analyses were run at an inferred reservoir temperature of $40^{\circ} \mathrm{C}$. The volume of methane (standard cubic feet,or SCF) adsorbed to create a saturated monolayer in moist (equilibrium moisture), ash-free samples ranged from $64 \mathrm{SCF} /$ ton (00DL43A Deepbank Creek) to $309 \mathrm{SCF} /$ ton (00DL33E Windy Fork). The thermal maturity of coals and carbonaceous mudstones is low, reducing the ability of these lithologies to adsorb methane. If Tertiary age coals and carbonaceous shales are present near the base of the Holitna basin $(4,000+$ meters depth), the adsorption capacity may be higher.

High pressure methane adsorption data for the six samples and details on the test methodology are available from DGGS (Raw Data-file 2002-2). It is important to emphasize that all samples were collected from outcrops subjected to surface weathering processes. The freshest material available, obtained by hand excavating the outcrop, was

sampled in every case. It should also be pointed out at these data are not a measure of the actual gas content of coals and carbonaceous mudstones in outcrop, but are an indication of the gas holding capacity of these lithologies. Meaningful gas content data (desorption data) can be obtained on subsurface core samples that are containerized immediately after removal from the core barrel. For more information on adsorption isotherms and desorption measurements, the reader is referred to A Guide to Determining Coalbed Gas Content published by the Gas Research Institute (GRI Reference No. GRI-94/0396).

\section{Rock-Eval Pyrolysis}

A small suite of 12 samples of claystone and carbonaceous mudstone were submitted to Baseline-DGSI, Inc., in Houston, TX, for Rock-Eval pyrolysis analysis (Table 2). A brief summary of the Rock-Eval technique is presented below followed by discussion of Rock-Eval sample results.

The Rock-Eval pyrolysis technique involves heating a small quantity of ground sample to $300^{\circ} \mathrm{C}$ in a helium atmosphere and maintaining that temperature for 3-4 minutes to pyrolyze the sample (Peters, 1986). The sample chamber is connected to a flame ionization detector that senses any organic compounds liberated from the sample during initial heating. Following initial heating, the sample is step-heated at $25^{\circ} \mathrm{C} /$ minute up to $550^{\circ} \mathrm{C}$. The output from Rock-Eval pyrolysis includes the concentration of organic 
carbon (TOC in weight percent) and three peaks, referred to as S1, S2, and S3 (each expressed in $\mathrm{mg} / \mathrm{g}$ ). The $\mathrm{S} 1$ peak represents the products evolved at pyrolysis temperatures up to about $300^{\circ} \mathrm{C}$. The $\mathrm{S} 1$ peak represents free hydrocarbons (bitumen) in the rock prior to analysis. The S2 peak represents the amount of hydrocarbons evolved during thermal degradation of kerogen. The S2 peak is a measure of the amount of hydrogen-rich kerogen is present in a source rock - that is, it represents the amount of hydrocarbons that the rock can generate if heated to sufficient temperatures. The temperature associated with the $\mathrm{S} 2$ peak is referred to as $\mathrm{T}_{\max }$, a parameter that provides information about the thermal maturity level of the sample. $\mathrm{T}_{\max }$ has been shown to increase as the thermal maturity of the sample increases. The $\mathrm{S} 3$ peak is related to the amount of $\mathrm{CO}_{2}$ generated during the pyrolysis process. The area under each peak is related to the volume of hydrocarbons or $\mathrm{CO}_{2}$ generated (expressed in milligrams per gram).

Several bulk parameters can be derived from Rock-Eval pyrolysis data. The most significant parameters for the purpose of the Holitna basin study are the hydrogen index (HI) and oxygen index (OI). Formulas for each of these parameters can be found in Peters (1991). The HI corresponds to the quantity of hydrocarbons from S2 relative to TOC; the OI corresponds to the quantity of $\mathrm{CO}_{2}$ relative to TOC. Both indices are commonly displayed graphically on a modified Van Krevelen diagram by plotting the HI on the $y$-axis and the OI on the x-axis (Jacobson, 1991). This type of diagram allows visual discrimination of kerogen type (type I, II, III, and IV). Type I kerogen is characterized by high HI values (greater than 400 to 500) and very low OI values (less than 25 to 30); type IV kerogens have very low HI values (less than 75) and variable OI values. Types II and III kerogens are intermediate between those two end members. Type I and II kerogens are capable of generating liquid hydrocarbons; Type III kerogen is gas-prone; Type IV kerogen is widely regarded as inert and incapable of generating hydrocarbons (Peters, 1986).

Eleven samples of carbonaceous mudstone and claystone were submitted for Rock-Eval pyrolysis (Table 2 and Fig. 16). The organic carbon content ranges from 0.06 weight percent to 15.76 weight percent TOC (Table 2). Of the 11 samples, one has less than 0.5 percent TOC, indicating poor generative potential; four samples have 1-2 percent TOC, indicating good generative potential; and six samples have greater than 2 percent TOC, indicating very good generative potential (see Table 1 in Peters, 1986). S1 are all 
less than $0.9 \mathrm{mg} / \mathrm{g}$ and indicate the rocks are thermally immature and little, if any, hydrocarbons have been generated. S2 ranges from $0.02 \mathrm{mg} / \mathrm{g}$ to $60.32 \mathrm{mg} / \mathrm{g}$ and suggests significant hydrocarbon generative potential for some samples (Table 2). By comparison with S2 values in Peters (1986, his Table 1), five samples have poor generative potential, two have fair generative potential, and four have S2 values suggesting goo to very good generative potential. A plot of HI versus OI shows that most samples contain type III and/or IV kerogen. Two samples (00DL49-265 and 00DL49327.5) collected from the thick lacustrine succession exposed at the north end of the Middle Fork exposure contained HI values of greater than 380 and plotted near the type II kerogen pathway, suggesting potential for liquid hydrocarbons (second play identified above). It may be notable that palynologic samples from this same stratigraphic interval yielded abundant fungal remains and conifer pollen that may have contributed type II kerogens. However, some coal known from elemental analysis to consist of humic (type III) kerogen plot between type III and type II on modified Van Krevelen diagrams due to poorly understood analytical problems with Rock-Eval apparatus (Peters, 1986). As a result, plots of HI vs. OI may misrepresent kerogen type and the data shown in Figure 16 should be viewed with caution.

Six of the 11 samples have elevated OI values (greater than 50), probably owing to surface weathering. Surface weathering tends to result in lower HI and TOC levels, and elevated OI values, thus making the results overly pessimistic.

\section{Kerogen Microscopy}

Three samples from the lacustrine succession exposed along the Middle Fork were submitted for kerogen microscopy. The following information was taken from a report submitted to DGGS by the laboratory (Baseline-DGSI).

Sample 00DL48-2 included organic material consisting of large, lipid-rich vitrinite fragments and unstructured material with very small lipid-rich vitrinite inclusions. Lipid-rich vitrinite is slightly soluble in immersion oil. Unstructured material may be degraded humic debris or oxidized unstructured lipids.

Samples 00DL49-265 and 00DL49-327.5 included organic material consisting of lipid-rich vitrinite fragments with liptodetrinite inclusions and a small amount of unstructured material. Lipid-rich vitrinite in both samples is slightly soluble in immersion oil. Sample 00DL49-265 included abundant liptodetrinite that fluoresced. 
To summarize, all three samples contain primarily humic (coaly) organic material, primarily consisting of lipid-rich vitrinite. Samples 00DL49-265 and 00DL49-327.5 include lipid-rich vitrinite with fluorescing liptodetrinite inclusions. According to the laboratory (Baseline-DGSI), this material is responsible for the high HI values and low pyrolysis Tmax compared to other samples, and indicates some ability to generate wet gas and possibly some condensate or light crude oil (conventional oil play). Encouraging as the results from these two samples are, they may not be representative of the source rock potential over a greater stratigraphic thickness or a wider geographic area. Kerogen microscopy (and whole extract gas chromatography data not discussed in this report) are available for DGGS (Raw Data-file 2002-xx).

\section{Thermal Maturity}

Vitrinite reflectance (termed $\mathrm{R}_{\mathrm{o}}$ ) data is widely used in the oil industry as an indicator of organic maturation (thermal maturity) in sedimentary rocks. Its value comes from an empirical relation between the reflectivity of vitrinite, maximum temperature a rock (containing fragments of vitrinite) has been experienced, and petroleum generation (Tissot and Welte, 1984). Organic maturation data can be used along with estimates of the geothermal gradient to calculate depth of burial required to initiate oil and gas generation. The threshold for oil generation is $0.6 \% \mathrm{R}_{0}$; the threshold for methane generation is about $0.8 \% \mathrm{R}_{\mathrm{o}}$. Organic maturation information (such as vitrinite reflectance) combined with information on the geothermal gradient (typically bottom hole temperatures obtained in nearby exploration wells) allow calculation of the burial depths required for the onset of oil and gas generation.

Vitrinite reflectance $\left(R_{0}\right)$ measurements were obtained from samples submitted for coal petrology and kerogen microscopy (Table 3 ). $\mathrm{R}_{\mathrm{o}}$ measurements were made on several fragments of vitrinite in each sample. Mean $R_{o}$ values range from 0.14 to 0.64 and indicate the Tertiary section in outcrop is immature to marginally mature with respect to oil generation (oil window). Vitrinite reflectance between 0.6 and 1.0 define the oil window; $\mathrm{R}_{\mathrm{o}}$ values between 1.0 and 1.3 define the wet gas window. Vitrinite reflectance values between 1.3 and 4.0 define the dry gas window and indicate source rocks that are

post-mature. These data are consistent with Tmax values shown in Table 2 and published $\mathrm{R}_{\mathrm{o}}$ data (Solie and Dickey, 1982). 
Vitrinite reflectance data from the McGrath Quadrangle indicate that the carbonaceous and coal-bearing successions there could not have generated thermogenic hydrocarbons. However, gravity data from the Holitna basin to the southwest suggest up to $4,500 \mathrm{~m}(14,600 \mathrm{feet})$ of Tertiary strata. If carbonaceous mudstones and coals are present at depth in the Holitna basin, $\mathrm{R}_{\mathrm{o}}$ values would probably be significantly higher. The depth to the oil window $\left(0.6 \% \mathrm{R}_{\mathrm{o}}\right)$ and gas window $\left(0.8 \% \mathrm{R}_{\mathrm{o}}\right)$ can be calculated if the geothermal gradient is known. Using bottom hole temperatures from two wells in the Nenana basin and data from Barker and Pawlewicz (1986) on $\mathrm{R}_{\mathrm{o}}$-burial temperature correlations, Stanley (1991) estimated the depth to the top of the oil window in that basin between $1,400 \mathrm{~m}$ to $2,700 \mathrm{~m}$ (4,536 feet to 8,748 feet). Tyler and others (1998) used data

from the Beaver Lakes State \#1B well in the northern Susitna basin to estimate the depth to the top of the gas window in the Minchumina basin (east of McGrath and northeast of the Holitna basin) at greater than 3,086 m (greater than 10,000 feet). These estimates may apply to the Tertiary Holitna basin if the geothermal gradient derived from the two Nenana basin wells and the Susitna basin well are valid for the Holitna basin.

Vitrinite reflectance data from this project are available from DGGS (Raw datafile 2002-xx). Additional vitrinite reflectance data on the Tertiary section in outcrop are available in Sloan and others (1979) and Solie and Dickey (1982).

\section{Summary of Shallow Gas Potential}

Available data suggest that coal and carbonaceous mudstone are the most likely potential source rocks for petroleum in the Holitna basin. Hydrocarbons generated in the basin could be sorbed to coal and carbonaceous material or stored in conventional sandstone and conglomerate reservoirs. Interbedded coal, carbonaceous mudstone, conglomerate, and sandstone in outcrop suggest that reservoir lithologies would have ample access to petroleum charge. However, visible porosity is lacking in outcrop samples, suggesting low reservoir potential for sandstones and conglomerates, thereby reducing the chances for success in the conventional gas and oil plays. The coalbed methane play is discussed below.

Tyler and others (1997) compared the geologic and hydrologic characteristics of San Juan, Greater Green River, and Piceance basins in the Lower-48 states in an attempt to explain differences in coalbed methane production. Through this process they developed a coalbed methane producibility model that incorporates geologic and 
hydrologic factors considered critical to high coalbed methane production. Important geologic and hydrologic factors influencing coalbed methane producibility include: 1.) a depositional setting for coal-bearing strata favorable for deposition of thick, laterally continuous coal seams [and carbonaceous mudstone successions]; 2). tectonic and structural setting for the coal basin that maintains the necessary balance between subsidence rate and peat accumulation or promotes deposition of thick carbonaceous mudstone successions; 3.) coal rank and gas content - higher rank coals generate greater volumes of methane; and 4.) basin hydrogeology characterized by regional ground water flow from uplands, where thick laterally continuous coals are exposed to meteoric recharge, basinwards to no-flow boundaries such are fault zones and fold hinge lines, where gas can be resorbed and trapped in conventional reservoirs. If the Tertiary section in outcrop is a valid analog for the Holitna basin, the basin fill probably includes a thick succession of alluvial deposits, including organic-rich flood plain deposits, and lacustrine strata.

The original extent of coal swamps and larger lake basins in the Holitna basin was probably influenced by faulting and fault-induced subsidence. Coal swamps and larger lake basins may have been elongated parallel to fault trends, which in this area strike northeast-southwest. Most coals in outcrop are thin and likely to be laterally discontinuous - the Little Tonzona River coals are a notable exception - and by analogy coals in the Holitna basin may be similarly thin and discontinuous. Carbonaceous mudstone successions in outcrop are thick (100s of meters) and probably characterized by greater lateral continuity. Coals and carbonaceous mudstones in outcrop are submature with respect to both oil and gas generation. At the depths necessary to generate thermogenic methane, the coal cleat system (orthogonal fractures in coal) and fractures in carbonaceous mudstones are likely to be closed. This reduces that ability of the rock to transmit methane in the fracture system.

Given the low thermal maturity of coal and carbonaceous mudstone in outcrop, gas contents in similar lithologies in the basin would likely be relatively low above a depth of 3,100 m (approximately 10,000 feet), unless thermogenic gas from deep in the basin migrated into shallow coal beds or biogenic gas is an important component. Biogenic gas may be present in the basin-fill. Coal gases in the Powder River Basin are entirely biogenic and biogenic gases account for a significant proportion of shale gases from the Antrim Shale in the Michigan Basin (Scott, 2001). Several shallow gas fields 
are present in Miocene to Pliocene age rocks in the Cook Inlet Basin (Claypool and Magoon, 1980). Geologic and geochemical evidence suggests that gases in these Cook Inlet fields are accumulated marsh gas of biogenic origin. These shallow Cook Inlet gas field may serve as analogs for the Tertiary Holitna basin.

Data on regional ground water flow patterns in and around the Holitna basin are not available, but regional ground water probably flows toward the northwest and southeast from the Alaska Range and Kuskokwim Mountains, respectively. Regional flow paths probably converge in the vicinity of the Kuskokwim River, which flows parallel to and just to the northwest of the basin axis (fig. 1). The absence of exposures of Tertiary coal- and carbonaceous mudstone around the perimeter of the basin suggests that regional ground water flow is not directed through thick, laterally continuous coals and carbonaceous mudstones, thereby reducing the chance for biogenic gas.

For the reasons outlined above and due to potential structural complexities, any accumulations, if present, are likely to be small and non-commercial. Kirschner (1994) arrived at a similar conclusion. However, a small- to moderate-sized gas accumulation (100 to 200 billion cubic feet) could represent a significant resource for local consumption.

\section{CONCLUSIONS}

The Alaska Division of Geological and Geophysical Surveys evaluated the shallow gas potential of the Tertiary Holitna basin using high-resolution aeromagnetic and gravity surveys and detailed studies of outcrops of Tertiary sedimentary rocks along the Alaska Range mountain front from the Little Tonzona River to the Cheeneetnuk River. The task of reprocessing and interpreting the geophysical data sets was performed by a geophysical contractor. The results of the geophysical investigation will be summarized in a final geophysical report in 2002.

The closest exposures of Tertiary strata to the Holitna basin are located approximately $20 \mathrm{~km}$ away, along the Cheeneetnuk River in the northern Lime Hills Quadrangle and southwestern McGrath Quadrangle, where mudstone with thin coal stringers are present in small overgrown exposures along the north bank of the river. Coal and carbonaceous mudstone are absent near White Mountain in the McGrath Quadrangle, where over $500 \mathrm{~m}$ of conglomerate, pebbly sandstone, and siltstone are exposed south of the Cheeneetnuk River and are interpreted as products of high-gradient, low-sinuosity streams and adjacent flood basins. Between the Middle and Windy forks 
of the Kuskokwim River over 1,000 m of Tertiary strata are exposed along river banks. In this area, the southern two-thirds (stratigraphic base) of the outcrop belt is dominated by coarse-grained lithologies similar to those recognized near White Mountain and are similarly interpreted. The northern third (stratigraphic top) of the outcrop belt consists of carbonaceous mudstone, thin high-ash coal stringers, and scatted thin pebble conglomerate, sandstone, and siltstone beds that are interpreted as lacustrine deposits. The thickest and cleanest (low-ash) coal is located at the northeast end of the outcrop belt, between Deepbank Creek and the Little Tonzona River, where individual seams up to $12 \mathrm{~m}$ thick have been documented. Biostratigraphic data suggest that rocks become progressively younger to the southwest, from the Little Tonzona River (late Eocene to early Miocene) to the Lower Cheeneetnuk River (middle to late Miocene).

The relation between the outcrop section and the subsurface Holitna basin remains unknown. The apparent age progression from late Eocene-early Miocene at the Little Tonzona River to middle to late Miocene in the lower Cheeneetnuk River area suggests that that fill of the basin to the southwest may be middle Miocene or younger in age. This assumes the age progression in outcrop is a reflection of deposition in a single depositional basin, but the validity of this assumption is unknown. The outcrop belt may represent deposition in multiple disconnected basins that have no spatial relation to the subsurface Holitna basin.

The reservoir and trap potential is probably poor. Conglomerates are wellindurated, clast-supported, and have poorly sorted sandstone as matrix between clasts. The sandstone matrix in conglomerates lack visible porosity in outcrop. Similarly, sandstones are generally tightly cemented and lack visible porosity in outcrop. Clast composition and sandstone composition indicate a low-grade metamorphic provenance; notable exceptions are presentt along the Khuchaynik River, where one conglomerate succession includes a high percentage (over 50 percent) of limestone clasts. Traps are likely to complex structural (faults and faulted folds) and combination stratigraphicstructural traps.

Suitable seal lithologies have not been recognized in outcrop. Coal and carbonaceous mudstones are often silty and only rarely "clean" claystones. This suggests that seal lithologies will be leaky.

Carbonaceous mudstone, lignite, and sub-bituminous coal at the Little Tonzona River, Windy Fork, Middle Fork, and Cheeneetnuk River localities are potential source 
rocks. Coal petrology, Rock-Eval pyrolysis, and kerogen microscopy indicate abundant type III and IV kerogens and the potential to generate gas. Limited Rock-Eval pyrolysis data also suggest the presence, at least locally, of lipid-rich vitrinite (HI over 380 in two samples) in the lacustrine succession at the north end of the Middle Fork exposure. Baseline-DGSI, Inc. suggests that this organic facies may be capable of generating wet gas, condensate, or possibly light oil. We caution the reader to avoid drawing overly optimistic conclusions from these data as our data set is very limited. DGGS plans to collect a more extensive Rock-Eval sample suite during the 2002 field season.

Vitrinite reflectance data indicate the outcrop section is submature to borderline mature for oil (mean Ro between 0.14 and 0.62 ). These data suggest shallow burial to depths less than 1500 meters (less than 4,860 feet), depending on geothermal gradients. Shallow gas (less than 1,600 to 2,000 $\mathrm{m}$ depth) in the Holitna basin, if present, would have to have migrated from more deeply buried source rocks or have been derived from biogenic processes. Accumulations of biogenic gas, if present, are likely to be small as indicated by the structurally disrupted Tertiary section in outcrop to the northeast. Overall, the shallow gas potential of the Holitna basin is regarded as low to fair.

\section{ACKNOWLEDGEMENTS}

We thank Dr. Rick Stanley (U.S. Geological Survey) for reviewing the manuscript and providing many helpful suggestions.

\section{REFERENCES CITED}

Alaska Division of Geological and Geophysical Surveys 1973 Annual Report, p. 30-34. Barker, C.E., and Pawlewicz, M.J., 1986, The correlation of vitrinite reflectance with maximum temperature in humic organic matter, in Bunterbarth, G., and Stegena, L., eds., Paleogeothermics: Springer-Verlag, Lecture Notes in Earth Sciences, v. 5, p. 79-93.

Barnes, F.F., 1967, Coal Resources of Alaska: U.S. Geological Survey Bulletin 1242-B, $36 \mathrm{p}$.

Brooks, A.H., 1910, Mineral Resources of Alaska: Report on Progress of Investigations in 1909: U.S. Geological Survey Bulletin 442, p. 61

Brooks, A.H., 1911, The McKinley Region: U.S. Geological Survey Professional Paper Professional Paper 70.

Bundtzen, T.K., and Kline, J.T., 1986, Coal, peat, and geothermal potential of Kuskokwim area plan: Alaska Division of Geological and Geophysical Surveys Public-data File 86-88, 14p.

Bundtzen, T.K., Laird, G.M., Blodgett, R.B., Clautice, K.H., and Harris, E.E., 1994, Geology of the Gagaryah River area, Lime Hills C-5 and C-6 Quadrangles, 
southwest Alaska: Alaska Division of Geological and Geophysical Surveys, Public-data File 94-40, 17 pages, 1 sheet, scale 1:63,360.

Bundtzen, T.K., Harris, E.E., and Gilbert, W.G., 1997, Geologic map of the eastern half of the McGrath Quadrangle, Alaska: Alaska Division of Geological and Geophysical Surveys, Report of Investigations 97-14a, 34 pages, 1 sheet, scale $1: 63,360$.

Christie-Blick, N., and Biddle, K.T., 1985, Deformation and basin formation along strikeslip faults, in Biddle, K.T., and Christie-Blick, N., eds., Strike-Slip Deformation and Basin Formation, and Sedimentation: Society of Economic Paleontologists and Mineralogists Special Publication No. 37, p. 1-34.

Csejtey, B., Wrucke, C.T., Ford, A.B., Mullen, M.W., Dutro, T.J., Harris, A.G., and Brease, P.F., 1996, Correlation of rock sequences across the Denali fault in southcentral Alaska, in Geological Studies in Alaska by the U.S. Geological Survey, 1994, Moore, T.E., and Dumoulin, J.A., eds.: U.S. Geological Survey Bulletin 2152, p. 149-156.

Decker, J., and 10 others, 1994, Geology of southwestern Alaska, in Plafker, G., and Berg, H.C., eds., The Geology of Alaska: Boulder, Colorado, Geological Society of America, The Geology of North America, v. G-1. p. 285-310.

Decker, J., Reifenstuhl, R.R., Robinson, M.S., Waythomas, C.F., and Clough, J.G., 1995, Geology of the Sleetmute A-5, A-6, B-5, and B-6 Quadrangles, southwestern Alaska: Alaska Division of Geological and Geophysical Surveys, Professional Report 99, 16 pages, 2 sheets, scale 1:63,360.

Dickey, D.B., 1982, Tertiary sedimentary rocks and tectonic implication of the Farewell fault zone, McGrath Quadrangle, Alaska: unpublished Masters Thesis, University of Alaska-Fairbanks.

Dickey, D.B., 1984, Cenozoic non-marine sedimentary rocks of the Farewell fault zone, McGrath Quadrangle, Alaska: Sedimentary Geology, v. 38, p. 443-463.

Gas Research Institute, 1995, A Guide to Determining Coalbed Gas Content, Chicago, Illinois.

Gilbert, W.G., 1981, Preliminary geologic map and geochemical data, Cheeneetnuk River area, Alaska: Alaska Division of Geological and Geophysical Surveys, Alaska Open-file Report 153, 10 pages, 2 plates, scale 1:63,360.

Grantz, A., 1966, Strike-slip faults in Alaska: U.S. Geological Survey Open-file Report 267, $82 \mathrm{p}$.

Herreid, G., 1968, Geological and Geochemical Investigations southwest of Farewell, Alaska: Alaska Division of Mines and Minerals Geologic Report 26, 25 p.

Hickman, R.G., 1974, Structural geology and stratigraphy along a segment of the Denali fault system, central Alaska Range, Alaska: unpublished Ph.D. Dissertation, University of Wisconsin, Madison, $276 \mathrm{p}$.

Hickman, R.G., Craddock, C., and Sherwood, K.W., 1977, Structural geology of the Nenana River segment of the Denali fault system, central Alaska Range: Geological Society of America Bulletin, v. 88, p. 511-526.

Hickman, R.G., Craddock, C., and Sherwood, K.W., 1978, The Denali fault system and the tectonic development of southern Alaska: Tectonophysics, v. 47, p. 247-273.

Hickman, R.G., Sherwood, K.W., and Craddock, C., 1990, Structural evolution of the Early Tertiary Cantwell basin, south-central Alaska: Tectonics, v. 9, n. 6, p. 1433-1449.

Jacobson, S.R., 1991, Petroleum source rocks and organic facies, in Merrill, R.K., ed., Source and Migration Processes and Evaluation Techniques: American Association of Petroleum Geology, Treatise of Petroleum Geology, p. 1-11. 
Kirschner, C.E., 1994, Interior basins of Alaska, in Plafker, G., and Berg, H.C., eds., The Geology of Alaska: Boulder, Colorado, Geological Society of America, The Geology of North America, v. G-1, p. 469-493.

Lanphere, M.A., 1978, Displacement history of the Denali fault system, Alaska and Canada: Canadian Journal of Earth Sciences, v. 15, n. 5, p. 817-822.

McCabe, P.J., 1984, Depositional environments of coal and coal-bearing strata, in Rahmani, R.A., and Flores, R.M., eds., Sedimentology of Coal and Coal-bearing Sequences: International Association of Sedimentologist Special Paper 7, p. 1342.

Meyer, J.F., and Krouskop, D.L., 1984, Preliminary gravity data, Holitna basin, southcentral Alaska: Alaska Division of Geological and Geophysical Surveys, Report of Investigations 84-25, 6 pgs., 2 sheets, scale 1:500,000.

Nokleberg, W.J., Jones, D.L., Silberling, N.J., 1985, Origin and tectonic evolution of the Maclaren and Wrangellia terranes, eastern Alaska Range, Alaska: Geological Survey of American Bulletin, v. 96, p. 1251-1270.

Peters, K.E., 1986, Guidelines for evaluating petroleum source rocks using programmed pyrolysis: American Association of Petroleum Geologists Bulletin, v.70, n. 3, p. 318-329.

Pierson, T.C., and Costa, J.E., 1987, A rheologic classification of subaerial sedimentwater flows, in Costa, J.E., and Wieczorek, G.F., eds., Debris Flows/Avalanches: Process, Recognition, and Mitigation: Geological Society of America Reviews in Engineering Geology, v. 7, p. 1-12.

Plafker, G., Blome, C.D., and Silberling, N.J., 1989, Reinterpretation of lower Mesozoic rocks on the Chilkat Peninsula, Alaska, as a displaced fragment of Wrangellia: Geology, v. 17, p. 3-6.

Plafker, G., Hudson, T., and Richter, D.H., 1977, Preliminary observations on late Cenozoic displacements along the Totschunda and Denali fault systems, in Blean, K.M., ed., The United States Geological Survey in Alaska: Accomplishments During 1976: U.S. Geological Survey Circular 751-B, p. B67-B69.

Player, G.F., 1976, The Little Tonzona Coal Bed Near Farewell, Alaska: An Important Extension of the Coal Fields North of the Alaska Range: unpublished report, 17 p.

Reading, H.G., 1980, Characteristics and recognition of strike-slip fault systems, in Balance, P., and Reading, H.G., eds., Sedimentation in Oblique-Slip Mobile Zones: International Association of Sedimentologists Special Publication No. 4, Blackwell, London, p. 7-26.

Redfield, T.F., and Fitzgerald, P.G., 1993, Denali fault system of southern Alaska: an interior strike-slip structure responding to dextral and sinistral shear coupling: Tectonics, v. 12, p. 1195-1208.

Reed, B.L., and Nelson, S.W., 1980, Geologic map of the Talkeetna Quadrangle, Alaska: U.S. Geological Survey Map I-1174, scale 1:250,000.

Richter, D.H., and Jones, D.L., 1973, Structure and stratigraphy of eastern Alaska Range, Alaska, in Arctic Geology, Pitcher, M.G., ed.: American Association of Petroleum Geologist Memoir 19, p. 408-420.

Ridgway, K.D., 1992, Cenozoic Tectonics of the Denali Fault System, Saint Elias Mountains, Yukon Territory: Synorogenic Sedimentation, Basin Development, and Deformation Along a Transform Fault System: unpublished Ph.D. Dissertation, University of Rochester, Rochester, New York, 508 p.

Ridgway, K.D., Trop, J.M., and Sweet, A.R., 1997, Thrust-top basin formation along a suture zone, Cantwell basin, Alaska Range: implications for development of the 
Denali fault sytem: Geological Society of America Bulletin, v. 109, n.5, p. 505523.

Ridgway, K.D., Trop, J.M., and Sweet, A.R., 2000, Stratigraphy, depositional systems, and age of the Tertiary White Mountain basin, Denali fault system, southwestern Alaska, in Pinner, D.S., and Davis, P.K., eds., Short Notes on Alaskan Geology 1999: Alaska Division of Geological and Geophysical Surveys Professional Report 119, p. 77-84.

Sainsbury, C.L., 1965, Previously undescribed Middle (?) Ordovician, Devonian (?), and Cretaceous (?) rocks, White Mountain area, near McGrath, Alaska: Geological Survey Research 1965, Chapter C, U.S. Geological Survey Professional Paper 525-C, p. C91-C95.

Sainsbury, C.L., and MacKevett, E.M., 1965, Quicksiliver deposits of southwestern Alaska: U.S. Geological Survey Bulletin 1187, 89p., 8 plates.

Scott, A.R., 2001, A new energy resource: microbially enhanced gas generation: American Association of Petroleum Geologists Annual Convention, Official Program, v. 10, p. A182.

Sloan, E.G., Shearer, G.B., Eason, J.E., and Almquist, C.L., 1979, Reconnaissance survey for coal near Farewell, Alaska: U.S. Geological Survey Open-file Report 79-410, $18 \mathrm{p}$.

Smith, T.N., Clough, J.G., Meyer, J.F., and Blodgett, R.B., 1985, Petroleum potential and straigraphy of Holitna basin, Alaska: American Association of Petroleum Geologists, v. 69, n. 2, p. 308.

Solie, D.N., and Dickey, D.B., 1982, Coal occurrences and analyses, Farewell-White Mountain area, southwest Alaska: Alaska Division of Geological and Geophysical Surveys Open-file Report 160, 17 p., 1 plate.

Solie, D.N., Bundtzen, T.K., and Gilbert, W.G., 1991, K/Ar ages of igneous rocks in the McGrath Quadrangle, Alaska: Alaska Division of Geological and Geophysical Surveys Public-data File 91-23.

Stanley, R. G., McLean, H., and Pawlewicz, M.J., 1990, Petroleum source rock potential and thermal maturity of the Tertiary Usibelli Group of Suntrana, central Alaska, in Dover, J.H., and Galloway, J.P., eds., Geologic Studies in Alaska by the U.S. Geological Survey, 1989: U.S. Geological Survey Bulletin 1946, p. 65-76.

Tissot, B.P., and Welte, D.H., 1984, Petroleum Formation and Occurrence: SpringerVerlag, Berlin, 699p.

Tyler, R., Scott, A.R., Kaiser, W.R., and McMurry, R.G., 1997, The application of a producibility model in defining coalbed methane exploration fairways and sweet spots: examples from the San Juan, Sand Wash, and Piceance basins: Report of Investigations Number 244, Texas Bureau of Economic Geology, 59p.

Tyler, R., Scott, A.R., and Clough, J.G., 2000, Coalbed methane potential and exploration targets for rural Alaskan communities, final report: Alaskan Division of Geological and Geophysical Surveys Preliminary Interpretive Report 2000-2, $177 \mathrm{p}$.

Wahrhaftig, C. Wolfe, J.A., and Leopold, E.B., 1969, The coal-bearing group in the Nenana coal field, Alaska: U.S. Geological Survey Bulletin 1274-D, 30 pages.

Wahrhaftig, C., 1986, Cenozoic section in Suntrana, Alaskan in Hill, M.L., ed., Cordilleran section, Centennial Field Guide, Geological Society of America, Boulder, v. 1, p. 445-450.

Wolfe, J.A., Hopkins, D.M., and Leopold, E.B., 1966, Tertiary stratigraphy and paleobotany of the Cook Inlet Region, Alaska: U.S. Geological Survey Professional Paper 398-A, 29 p., 
Wolfe, J.A., and Tanai, T., 1980, The Miocene Seldovia Point flora from the Kenai Group, Alaska: U.S. Geological Survey Professional Paper 1105, 52 p., 25 plates.

Zippi, P.A., 2001, Palynology of Tertiary Holitna Outcrops, McGrath and Talkeetna Quadrangles: Alaska Division of Geological and Geophysical Surveys Preliminary Interpretive Report 2001-4, 20 p. 


\section{BASELINE DGSI}

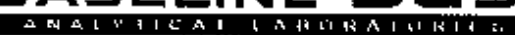

APPENDIX

GEOCHEMICAL ANALYSIS OF

CARBONACEOUS SHALES

HOLTTNA BASI, SOUTHWEST ALASKA

Prepared Jior:

Alaska Div. of Gool, \& Geophys. Surveys

794 Universily Ave, Suite 200

Frairbanks, AK 99709

Prepared By:

Wallace G. Dow

Baseline DGSI Project: 0 1-474G

October 3, 2001

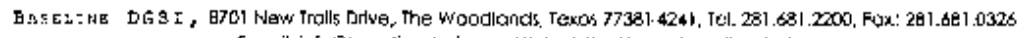

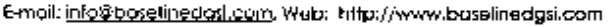




\section{DISCUSSION}

Twelve carbonaceous shales from outcrops in the lfolitng Busin, Southwegt Alaske wore analyzed according to client instructions. Organic carbon conlents vary greatly (0.06 to $15.76 \mathrm{wt}$ \% TOC) and Rock-Eval pyrolysis indieates low hydrooarbon yield, gas-only generaling, type III to type IV organic inatter in most samples (Figure 1). This low yield, howcver, may be due at least in part to outerop oxidation.

Three of the most organic-rich samples (Nos. 118,121 , and 123) with the highest hydrogen indjees (198 to 386) conlain more hydrocarbon generating capability than the others. These three samples were analyzed with kerogen microscopy and with solvent extract gas chroniatograplyy.

Kerogon microscopy shows that all three samples contain prinarily humic (cody) organic matter, primarily consisting of lipid-rich vitrinite (Appendix). Samples 121 and 123 contain lipid rich vitrinite with fluorescing liptodetrinite inclusions (see Appendix). This material is the reason for the high bydrogen indices and low pyrolysis $\mathrm{T}_{\max }$ values compared to the other samples and indicales some ability to generate wet gas and possibly some condentsite or light crude oil as well. Vitrinite reflectance maturitics range from 0.45 to $0.53 \% \mathrm{R}_{1}$, which is in the late inmature, pre-oil generation zone. This agross with the pyrolysis $\mathrm{T}_{\max }$ data (except for the samples with reduced $\mathrm{T}_{\max }$ values due to liptodetrinite), the immature appearance of the kerogen, and extract gas ohromatography results. This maturity at the surface, however, indicates subsiantial overburden removal since maximun burial and that hydrocarbon generation is eurrently suspendel.

The same three samples that were analyzed with kerogen microscopy yielded beween 897 and 6,138 ppm of total extract (Appendix). Whole cxtract gas chromatograms afe very charactoristic of imuature, terrigenous organic matter. High pr/ph ratios (Appendix) and the position of the samples on Figure 2 are consistent with this interpretation. Sample 118 with the lowest FOC content, HI ratio, and extract recovery is different than samples 121 and 123 which we both very similar. This agrees with the kerogen microscopy and the gas chromatography data. All three samples, however, contain immature, primarily terrigenous organic matter with little oil-generating eapability. It is noted that lower molecular weight hydrocarbons, less that about $\mathrm{nC}_{15}$, havc boen largely lost due to evaporation and this is the fraction that should be generaled in greatest abundance by the type of organic mialter present in the samples. 


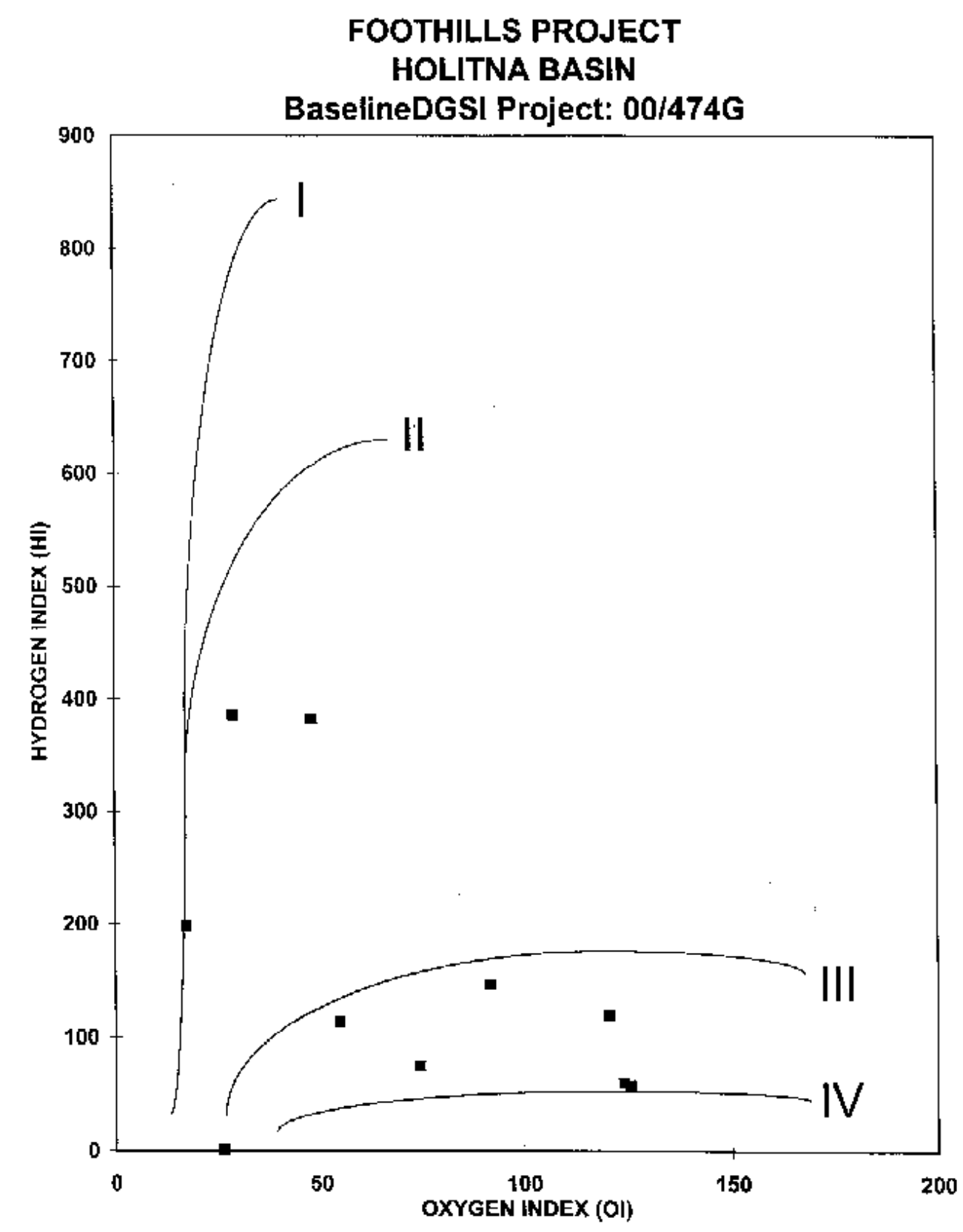

FIGURE -1 Kerogen type determination from TOC and Rock-Eval pyrolysis data. Types 1 and II will generate oll, type III gas, and type IV little or no hydrocarbons. 


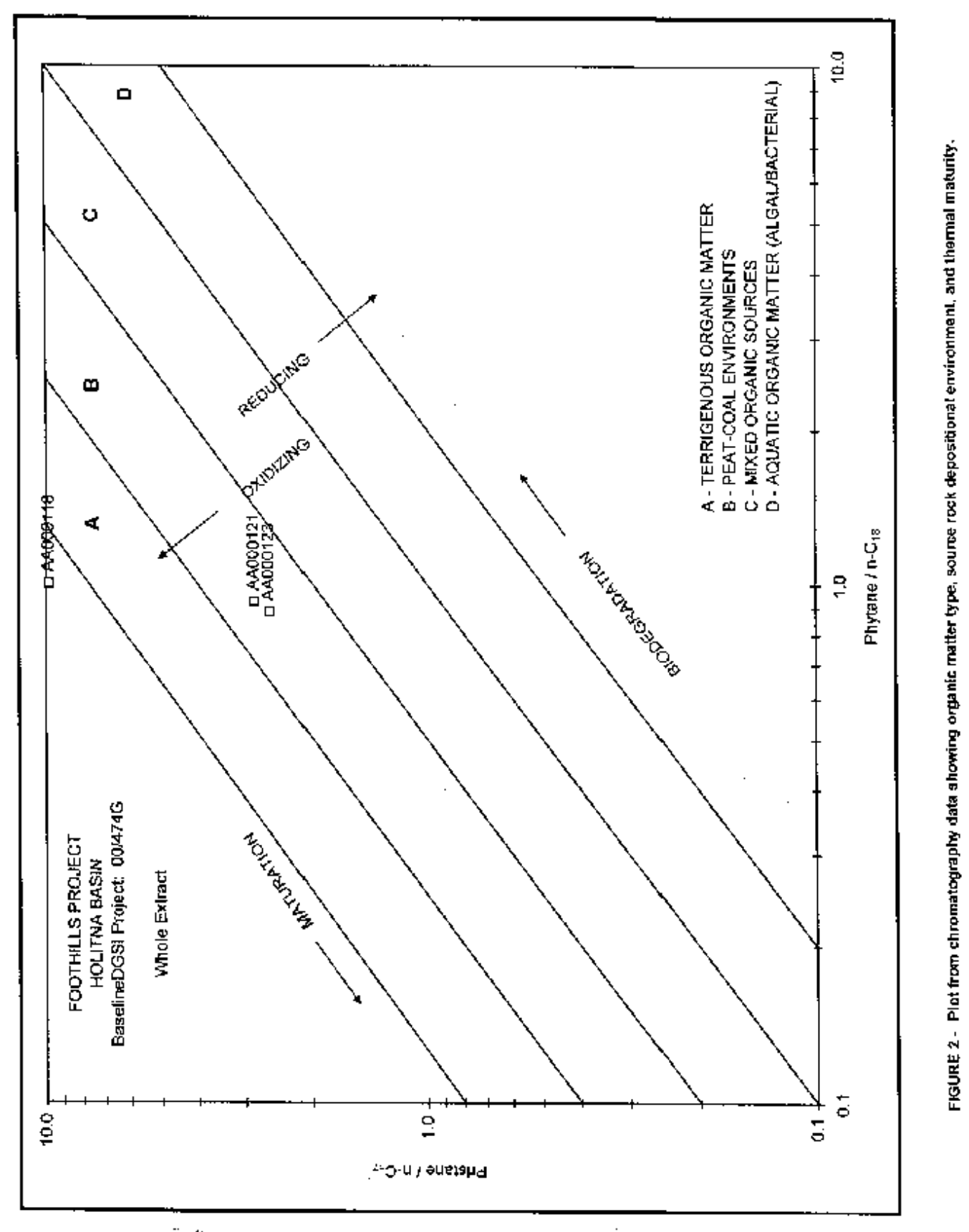




\section{ANALYSES BY ROCK-EYAL 6}

\section{KINETICS}

Reaction rate profiles deriwed fion pyrolysis FID are used to dettrminc activation erergy and fiequency factor kinetic perrameters. These kinetic parameters can be incorporated into hydrucarbon generation models to quantitatively simulate the thermal converaion of various ketogen types to vil and gras. Combining this data with basin modelling end geochemical ertalysis of the source ruck can prowide more accurale estinates of a source rocks" contribution tor oil andior gas is a basin and detertrine the tinjing of oil audior gass generation and migration.

Whole rowk or isolated kerogers are analyzed with the Rock-Ewal 6 by Vinci Technologies to acquire accurate temperature and reaction rute profiles. The instrungent contaitns a lemperuture measuring device at the sample being snilyzed and this redues the temperature corection factor mecessary to acquire accurate data. Heatine rates of $2,5,10,15$, and $25^{\circ}$ Chin. are niomally utilized to provide ratte profiles for the kerogen to nil generation. The dula are then processed uxing kinetics software developed by Latwrence Livenumore National Labotatories.

Tabuler ant graphical dats of the activation energy djutibution and the stiectud frequency factor are provided. Graplis of the meqasured and conjputed rate profiles are included.

\section{CARBONATE DETERMINATION}

A rock sumple is heated to $850^{\circ} \mathrm{C}$ during pyrolysis which deconposes the carlonates to yiuld $\mathrm{CO}$ and $\mathrm{CO}$ -

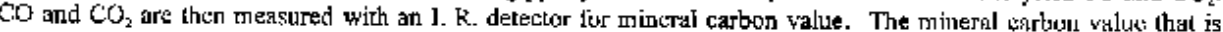
oblained is converted lo \% carbonate by using a molecular wi. formula which assumes that all earbortar is culcium warbonate.

\section{API' GRAVITY}

API gravity of oils, heaty oils and oil sliows is ugeful for identification and characterizatiuti. When

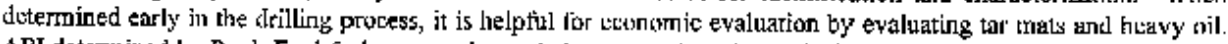
API deternined by Rock-Eval 6 shows good correlation to gravimetric results in the range of $30^{\circ} \mathrm{APl}$ or less. The recomended procchluse for eval uation requires a kuswn set of oils to be analyzed to establish a trend lint: Then a set of samples, either heavy uils or tars, may be evaluatud. It is possible for DGSI to provide existing established trend lines for cvaluation if necessary. (Trabelsi, K, J. Expitzlie, A. Y. Hue, IFP, "Characterizolion of" Exiru Hcuvy

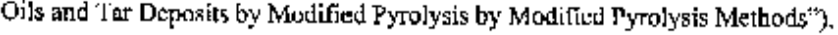

\section{ROCK-EVAI PYROLYSIS with TOC.}

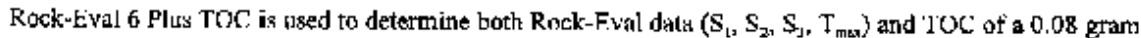
ground sample. With this instrument, the pyrolysis stage $\left(\mathrm{S}_{2}\right)$ remps to $650^{\circ} \mathrm{C}$ at which point the sample is switched to an oxidation oven where the sumple is oxidized at $850^{\circ} \mathrm{C}$ for 5 mimutres in air to measure the residual organie matter. $A$ laboratory standerd is rum every 10 samples. $S_{1}, S_{2}, S_{3}$, and residual oryanic matter are summed appropriately to calculate TOC. The extended temperature range of RF 6 overremes the shortcomings of the RLE If in TOC evaluation. The inf fratud detection of $\mathrm{CO}_{2}$ and $\mathrm{CO}$ alsn inj]roves its reproduchbility. 


\begin{tabular}{|c|c|c|c|c|c|c|c|c|c|c|c|}
\hline \multicolumn{12}{|c|}{$\begin{array}{l}\text { ORGANIC CAREON AND ROCK-EVAL PYROLYSIS DATA } \\
\text { FOOTHILLS PROJECT } \\
\text { HOLITNA BASIN } \\
\text { BaselineDGSI Project: 00/474G }\end{array}$} \\
\hline \multicolumn{2}{|c|}{ BAMPLEE IDENTIFIGATION } & $\begin{array}{l}\text { Toc } \\
\text { wilk }\end{array}$ & $\begin{array}{l}\text { S1 } \\
\text { sidg }\end{array}$ & $\begin{array}{l}\text { S2 } \\
\text { tmgin }\end{array}$ & $\begin{array}{l}53 \\
\mathrm{mg}\end{array}$ & $\begin{array}{l}\text { Tmax } \\
\text { degc }\end{array}$ & $\begin{array}{l}\text { Sit } \\
\text { Tac }\end{array}$ & HI & ol & $\begin{array}{l}\text { 521 } \\
51\end{array}$ & FI \\
\hline$A, 000118$ & 00DL5E-3日 & 3.09 & 0.04 & 3.72 & 3.73 & 492 & 1 & 120 & $12 \%$ & 1.00 & 0.011 \\
\hline A.ADO01 17 & ПОП АRА-7. & 132 & 0.01 & $0.8 n$ & 1.64 & 437 & 1 & 51 & 124 & 0.49 & 0.01 \\
\hline 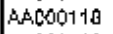 & $00 \mathrm{DL}+4-2$ & 8.45 & 0,09 & 16.76 & 1.46 & 425 & 1 & 1 & 17 & 11.48 & 000 \\
\hline AADOO119 & DODL5S-49.8 & 1.57 & 0.01 & 1.79 & 0.88 & $42 \mathrm{~B}$ & 1 & 114 & 55 & 2.08 & 0.01 \\
\hline 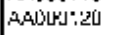 & 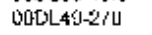 & 5.56 & 0.21 & 14.53 & ค. 79 & 428 & 2 & 147 & 92 & 7.60 & 0.09 \\
\hline Moto:121 & 00CL49-327.5 & 15.76 & 0.65 & 60.32 & 7.57 & 410 & 5 & 3es & 46 & 7.97 & ก:11 \\
\hline Mopo122 & $000<48-6,6$ & 394 & 0.02 & 2.96 & 2,94 & 437 & 1 & 75 & 75 & $\begin{array}{l}1.01 \\
+.01\end{array}$ & 0.1 \\
\hline$A A 000123$ & $000 \angle 49-255$ & 15.25 & 0.57 & 58.80 & 4.44 & 416 & 1 & 386 & 29 & 1324 & 0.01 \\
\hline A A 000124 & OCLL32F & $0.0 \mathrm{e}$ & 0.01 & 0.02 & 0,40 & 434 & 17 & 39 & 607 & 0.05 & D.93 \\
\hline A 4000125 & OOCLAGA 4 - & 1.65 & 0.01 & 0.96 & 2.09 & 440 & $\mathrm{j}$ & 뎌 & $12 \mathrm{E}$ & 0.45 & 0.01 \\
\hline Mo00126 & $010 \angle 42 \mathrm{C}$ & $\pi .62$ & 0.02 & 0.92 & 0.43 & Esg & 1 & 1 & 27 & 0.05 & 0.50 \\
\hline$A M 006127$ & $00 \mathrm{OL} 42 \mathrm{E}$ & 0.33 & 4.91 & 0.00 & 0.17 & N.A. & 3 & & 52 & - & - \\
\hline
\end{tabular}




\section{KEROGEN MICROSCOPY}

Visual kerogen analysis employs a Zciss Universal mieroscope system equipped with halogen. xenon, and tungsten light sources or a Jena Lurar microseope equipped witl halogen and mercury light sonuces. Vitrinite reflectarce and kerogen lyping are performed on a polizhed epoxy plag of unfloered kerogen concentrate usitig reflected lijht from the halogen source. In certain siluations, the whote fock is uscd for analysis. 'This approach is used for coals, where actd treatment is unnevessary in studies of suliel bilumen and graptolites where preservation of roek struchure is important, and in samples too small for ucid treatnent. The digital indicator is colibrated using a glass standard with a veflectance of $1.02 \%$ in oi]. This

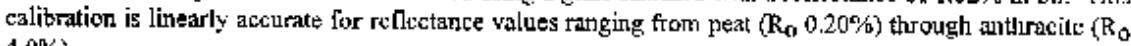
$4.0 \%)$.

\section{Vitrinite Reflectance}

Reflectance walues art reerrded only on good quality vitrinite, including obvious contamination and recycled material. 'lihe releive abundance of nomal, altered, lipjd-ijeh, oxidized, and coked vitrinite is rourded. When good qualily, mornal vitrinite is absent, notatious ure made indicating how the maturity is aflected by weathering, uxidution, bitumen saturation, or cokitug. When normal virrinite is absent ot sparse, other macerals fudy be substinited. Solid bitumen, for example is present in many santples. Although solid bitumet has a di fferent reflectance than witrinite, Landis and Castano's calibration thart is used to obtaim an estimeted vitrinite reflectance equivalent. Graptolit's have a slightly higher seflectance than vitrinite and can oflett be used to nbtain maturity datn in Uppur Cembrian-Silurian rocks that have no vilrinite.

Matulity ealeulatiuns are made from the vitrinite rellectuncel histoyrams. Decisionts as to wrichl renectance measurements indicate the maturity of the sample are bustol not only on the histogtam but on alf of the kerogen descriptiws clements as well. Because it is hol. donc ut the tirne of measuremerst altemate maturity calculations can be made if kerogen data and geologicol inlemation dictate.

DGS1's vicrinite reflectance hisrogtans eontrain much usc[ul inforration. Alf reflectance measurenens are graghically displated and the indivitual ruadings are listed below the histogran in numeric order. [n the reflectance table, each reading is colded wilh a letter corresponding to the measured maceral. Capibal letters are used to designate reflectinere valuss that are used in calculating the mean Feflectance while roflectance values, falling autside the selected range are shown with a lower care letter code. Reflectance roadings lying inside the selected range are markud with a patterd on the histogram diagran and reading: Falling outside the selected range are lefl upen. Each maceral has a different pattem.

Codes curently in use include: Solid hitumen - B, Granular solid bitumen - X, Coked solid bitnmen -Y, Graptolites - G, Inertinite - I, Otherl - 0, Other2 - W, Vitrinite - $V_{+}$Lipld-rteh vitrinite $-L_{\text {* }}$ and Cohed Vitrinite $-\mathrm{Z}$. The use of two 'other' eategories allows us the flexibility of measuring unusul malcribls thar do not fall into ore of the oller clusses or contamination from mud additives or caving. Specific information regarding "other" unelerial is shown in the Comments section at the lower right cormer of the Figure and in the Comments section of the VKA data sheet.

Statistics for selected nacerals ale lister adjacent to the histogram and the mean reflectance values arc also listed below the TOC and Rock-Eval deta at the upper right comer of the Figure. The measured reflectance values for solid bitumen and graptolites are recalculated in order to obtain a vitrinitc renectance equivalent (VRE). Therefore, For these two macerals we show both the mearured reflectance end the VRE. For example, VRE-Hs signifies vitrinile reflectance equivalent for solid bitumetr and VRE:G is the vitrinite reflectance equivalest for greptulites.

lin summary, vitinite reflectance measurements are performed on a polished plug in reflected light, TAI is performed on a slide in transtrilted liuht, and kerogen typing is estimated from hotll prepararions using a combination of reflected, transmitted, and fluorescent light techniques, Fluoresenene in blue light is used to enhance the identification of structured and unstrucoured lipid material, soticl bilumens, and drilling mud contaminants. Fluorescence also correlates with the maturity and stote of prestrvation of the sample. Maturity calculations from measured reflectones data are made from the hlsuingrams and are infuenced by all of the kcriggen data. 


\section{Visual Kerogen Analysis Techniques}

Unstratured lipid kerogen changes in texture snd color during the foaturation process. Typically, unsmuctired kerogen at low maturity is reddish brown and amorphous. Somewhere betweer $R_{0,} 0.50$ to $0.65 \%$, the kerogeit takes on a massive texture aud is gray in color. At higher mahurity, generally above $\mathrm{R}_{\mathrm{h}}$ $1.30 \%$, unstructured kergen is light gray and micrinized.

Kerogen typing and manuriby assensments from the polished plug are enhanced by utilizing fluorescence from blue light excitation. The xenton or mercury lamp is used with all excitation filter at 495 nm coupled with a barrier filter of $520 \mathrm{~nm}$. With the Jcna microseope we also have the option of observiny fluorescence under ultrayiolet excitation. The intinsily of fluorescentes in the epoxy mounting medium (backgtound fitureseence) correlates well with the onset of eil gencraticul and destuction. The identification of ylructured and unstruetures liptinite is also enhanced with the use ul nuoresence in those samples baving a maturity less than $\mathrm{R}_{\mathrm{g}} 1.3 \%$. The rqlative atundane and type of pyrile is also recorded.

Thertagl ulteration index (TAI) is porformed using tungstcn no halogen light source that is transmitted through a glass slide made from the unfloated kerogen concentrate. Idieally, TAl color is based on sporinite of terrestrial origin. When spurinite is absent, TAT is estimated from the unstructured lipid material. Weathering, birumen adtuxud with the unstructured blaterial and unicrinization can darken the kerogen and raise the TAI value. The character of the otgenic matter in lransmitted light is correlated with abservalions made in teflected light for kerogen typing.

Kerogen typing and thaturity assessments from the slide prepuration are also reinforced by uging differcht light souces. TJue slide is first obseryed in transmitled light to obtain 'TA1 color and grganic thatter structure or type. The light is then switched to reflected halngen light to observe stucture and amount of pyrite and finelly we reflected blus lisht excitation frim the xenon or thercury sourte for thorescence. The fluoreseterec of struenured and unstructured liptinite is not maskied by the eproxy fluorescence as it is in the reflected light modo because the jnounling medium is non-fluotescent, Lipits struttures (c.g. sponinite and alginite) within the unstructused kerogen ear sfter be jdentified in blue light.

\section{VISUAL KEROGEN ANALYSIS GLOSSARY}

Scweral key detinitions are included in this glossary in order to make utr reports more se]fexplanalory. In our reports, we lefter to organic substances as macerals. Mactrals are akin to minerals in rock in that they are organic constitulinls that have microseopically recren izable characteristics. [Iowewer, nucetats vary widely in their chemical nod physical properties and they are not orystalline.

l. UNSTRUCIULED KFROGEN is sometimes called structureless orgunic matter (SOWl or bituminite. It is widely beld that unstructured keroger represents the buckerial breakdown of lipid material. It also includes [teul pellets, minute partieles of algae, or'garie gills, and may contrin a humic componemt. As desiribed on the first page of this section, unstrueturad lipid kerogen changes character duting matulation. The three princjpal stages are amorphous, massive, and micrinized. Amompous kerngen is simply without any saucare. Massive kerugen has taken on a cohesive stricture, as the mesult of polymerization during the pracess of vil generation. $h$ thigh maturity, unstuctured kerogen becomes micrinized. Micrimite is characterized optically by an aggregation of very smail (less than one micron) round bodies that make up the kurogen.

2. STRUCTURED LIPID KEROGEN consists of a group of macerals which thite a reconnized structurc, and can be related to the ortieinal living tissue from which they were deriwed. There are noaky different types, and the types can be group folluws:

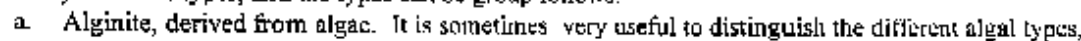
[or boryoeoceus and pediastom are associated with lacustrine and non-marinte souree rocks, while: algae such as tasmanites, gloecapsomorpha, and nostocopsis are typicully marim: Acrilarchs and dinoflegelates ate marine organisms which are also includod in thi algat ealugory.

b. Cutinite, derived from plant cuticles, the temains of leaves.

c. Resinite, (tincluding fluorinitc) derived [rom plant Jesins, balsans, latexes, and waxcs.

d. Sporinite, derived from sporcs and pollen frum a wide variecy of land plants.

e. Suberinite is derived from the corky tissue of land plants.

f. Liptodetrinite is that structurcd lipich material that is too snall to lre specifically islentified. Usually, it is derived from algeinite or sporinile. 
The aleae are an important par of many oil source focks, both marinc and lacostrine, Alginite hes a very bigh hydrogen index in Rock-Ewal pyrolysis. Resins, curicles, and suberinile contribute to the waxy, non-trarine oils thel are found in Africa atd the Far East. At witrinite reflectance levels abowis $\mathbf{R}_{0} 1.2-1.4 \%$, stuchured lipid kerogeth thanges structure and it becomes very alificifle to distimguigh ther from vitrinite.

3. SOLID BTTIMEN also is called migrahinumen and solid hydrosabon, In 1992 , the Intenutiunal Committes for Conl and Organie Petrology (ICCP) decided to include sold bitumen in the Exsudathite group. Solid bitumen are expelled hydrocarbon prodicts which have partisular mophology, retlectanee and fluoreserree properties which make it posaible to identify them. They

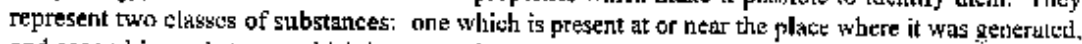
and second is a substance which is present it a regervoir rock and may have migated a great distance from its point of erigin. The solid binmeng have been giwen names, suck is gilsonite, imposouilt;

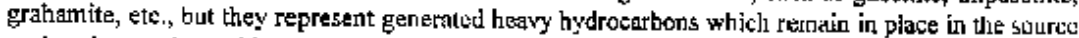
rock or have migrated into a feservoir end meture along with the tork. Corlsequently, it is possib]e [i] use the reflectance of solid binumens for maluration deteminations wher vitrinite is not presert.

4. HLTWIC TISSUE is organic matetial derived from the woody tissue of land plants. The morst importhnt uf this group are vitrinite and inertirite:

a. Vitrinilt is derived toon wody tisure which has been subjected to a minimum encum of

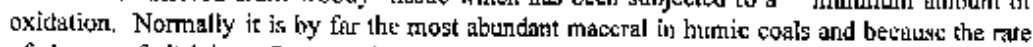
of shange of vitrinite teflectutes is at a more even pace than it is for other macerals, it whits the best mosans of obtaining thetrial maturity data itl coals and nther types of sedinentary rucks.

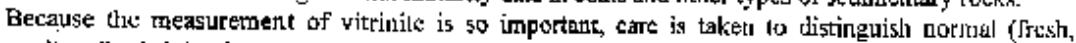
unaltered) wirrinite from other kinds of vitrinite. Rough vitrin ate ans not take a gool pulish and therefore may not yield gond dala. Oxidized viơinite may have a reflettance higler or liner than fisish vitrinite; this is a problsm often encoutnescd in onterop sumples. Lipid-rich viltinite, or sinprovitrinite, has a lower raflectance than nomal vitrinite and will produce an abutumally low thermal maturity yalue, Coked vitrinite is vitujite that has structures found in vitricuite hesated in a coke oven. Naturally coked vitrinite is the ptoduct of very sapid heating, such as thet found adjacent to intrusions. Where it is pussib]e to do so, vitrinte derived from an uphole portion of a wall will be iccortified as caved vituinite. Recycled vitrinize is the vitrinite of higher maturity which cluarly san be separated trom the indigenous first-cycle vituinite population, Oflen, the rescled vitrinite marege in with the inert group.

b. Inertinite is tsads up of woody tissue that has besc matured by a difterent pathway. Early

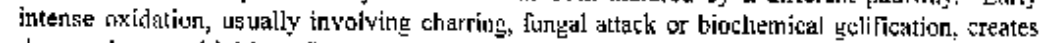

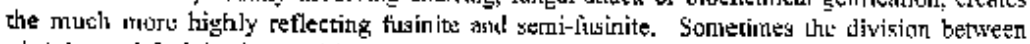
vitnite and lusinite is transitional. Sckoroticule, fungal remains heyitg a distinct morphology,

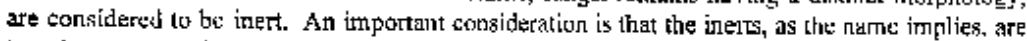

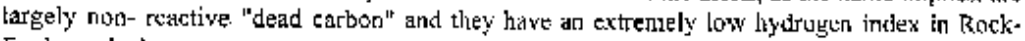
Eval pyrotyis.

5. OTHER ORGANIC MATEHAL

a. Lipid-rich, eaved and recycled vitrinitc. These are fut in this section so wit: cen show the percentagus of these macerals; they are described above

b. Exsudaticrite. Gil and oily exudates fall in this group. Exsudatinite differs lingm the solid bitutrisns on the basis of mobility and solubilily, we prefer to mainain this distinction although the ICCP has now included the soljat litumens in with line Exsudatinite group.

c. Gtoptolites are marine otganisms thas range from the Cambrian to the lowst Mississippian: ic

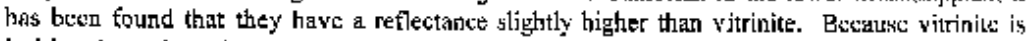

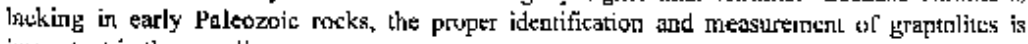
itrupurtant in these sedinismts.

6. PYRITE. Various fomm of pytitc can be radily jidentifiet under the microsctots. Fuhudral is pyrite with a durnite crystalline hebit. Franboidal is pyrile in the fom of grepe-like clusters which are

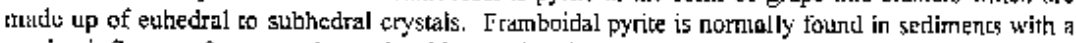
morino influence: for exathple, coals with a marine shale roof rock usully contain framboidal pyrite. Massive pyrite is pyrite with no parliculitextemal form. Ofter this is pyrite that forms rather late in thi pore spaces of the scdiment. Replacementinfilline is self-explandur?' 


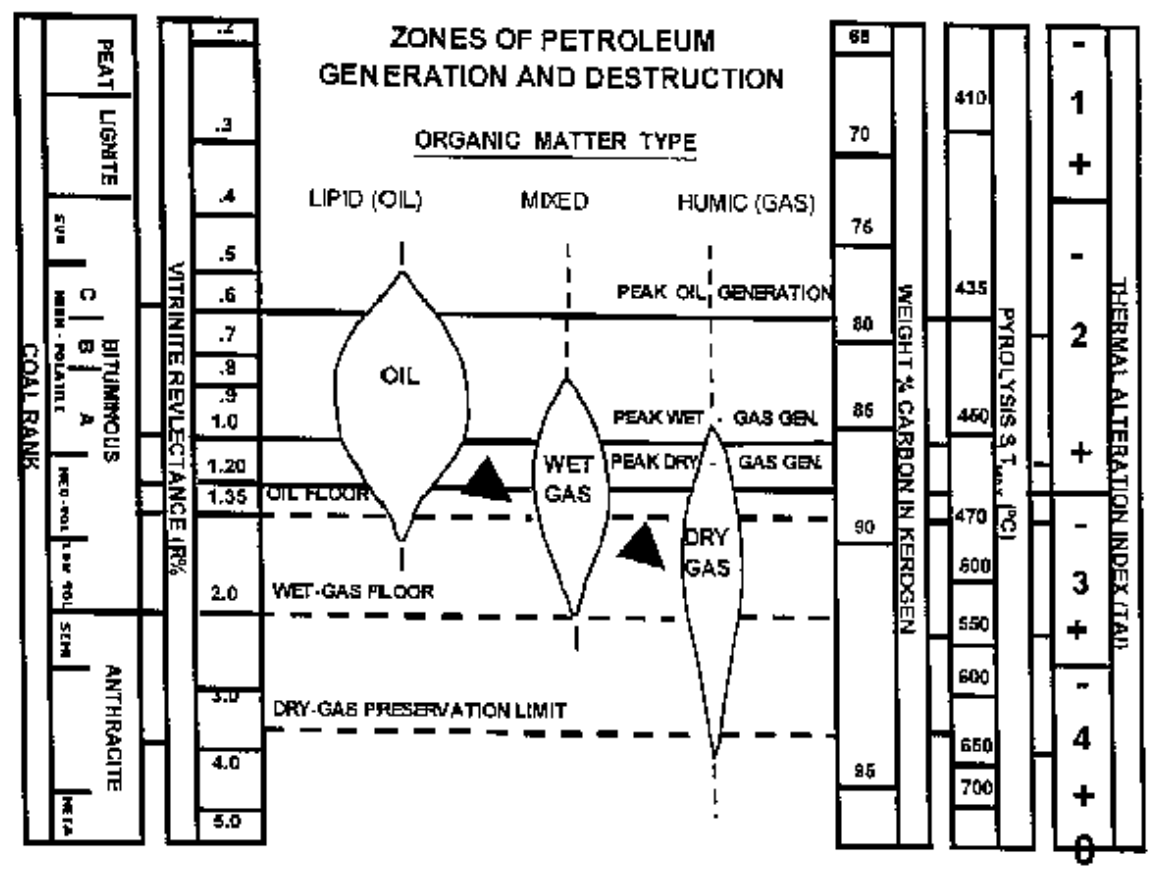

CORRELATION OF VARIOUS MATURATION INDICES AND ZONES OF PETROLEUM GENERATION AND DESTRUCTION 


\title{
FOOTHILLS PROJECT HOLITNA BASIN
}

\begin{abstract}
AA000118: 00DL48-2
Organic matter consists of large, lipid-rich vitrinite fragments and unstructured material with very small lipid-rich vitrinite inclusions. Lipid-rich vitrinite is slightly soluble in inmersion oil. Reflectance values were measured quickly, but sone values may stit be slightly lowered by rough texture or slight suppression. Unstructured materiai may be degraded humio debris of oxidized unstructured lipids. 'TAl walues on unstructured lípids may not be valid. Reflcctante, fluorescence, and pyrolysis data agree that maturity is just cntcring the top of the oil generation zone.
\end{abstract}

\begin{abstract}
AA000121: 000I 49-327.5
Organic matter consists ol lipid-rich vitrinito fragments with liptodetrinte inclusions and a small amount of unstructured material. Lipjd-rich vitrinite is slighty soluble in immersion oil. Some reflectance values may be slightly lowered by rough lexture or slight suppressian. Oxidation may cuuse unstructured lipids to appear more malure than they actually are. Reflectance and fluoreseence indicate the organic mattcr to be slightly immature, but near the lop of the oil window, Abundance of structured lipids may lower the $T_{\max }$ value.
\end{abstract}

\section{AA000123: 00DL49-265}

Organic matter consists of lipid-rich vitrinte fragnusuls with liptodetrinite inclusions, Flunrescing liptodetrinite is abundant when observed in the transmitted light slide. I.ipidrich witrinite is slightly soluble in immersion oil. Some reflectance values may be lowered by mugh texture, lipid content, or slight suppression. Roflectance and fluoresence indicate the orgenic matter to be slightly immature, but near the top of the oil window, Abutidance of structured lipid inclusions may lower the $\mathrm{T}_{\text {rax }}$ value. 


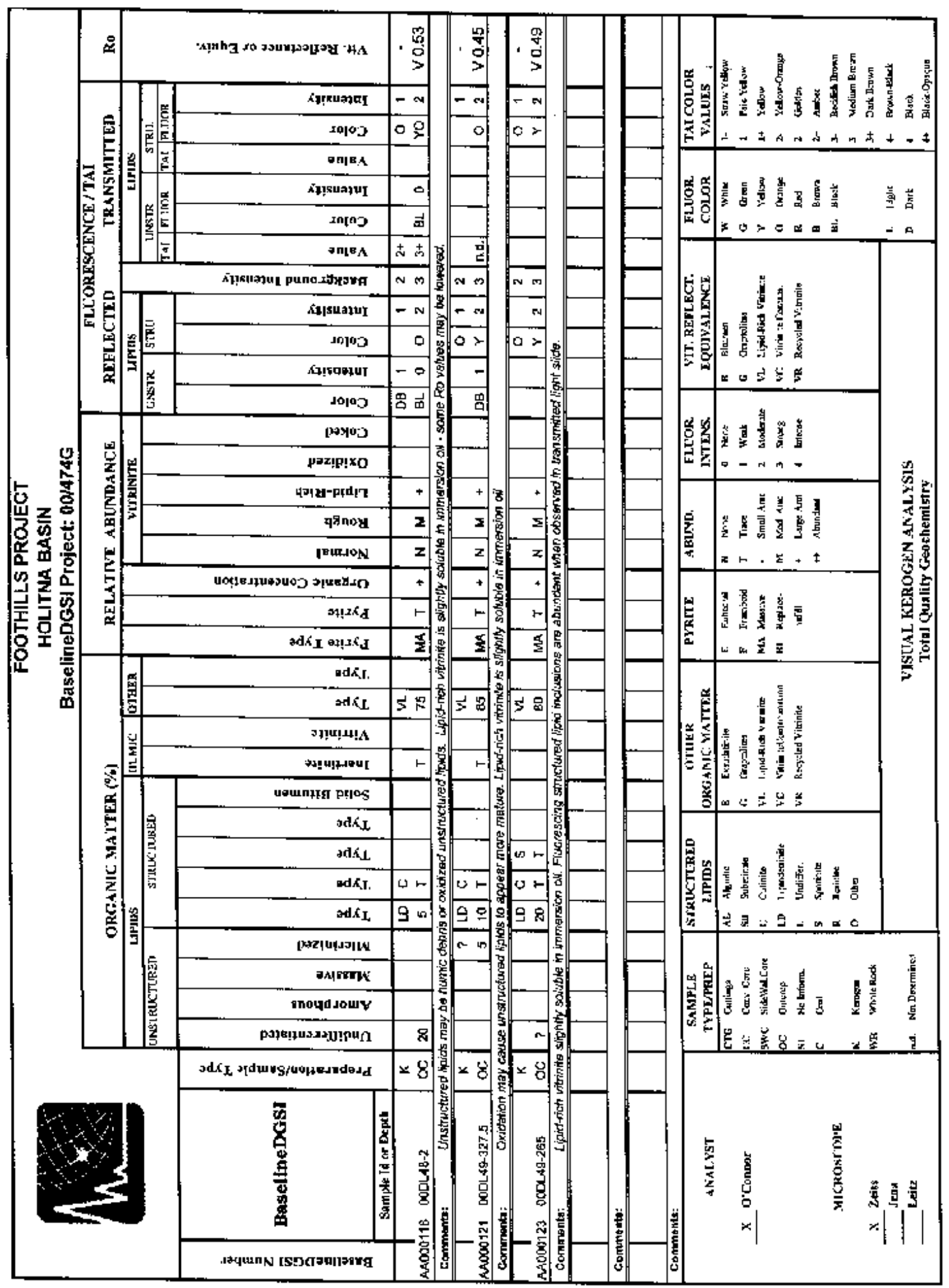




\section{VTTRINITE REFLECTANCF}

FOOTIILLS PROJECT

HOLITNA BASIN

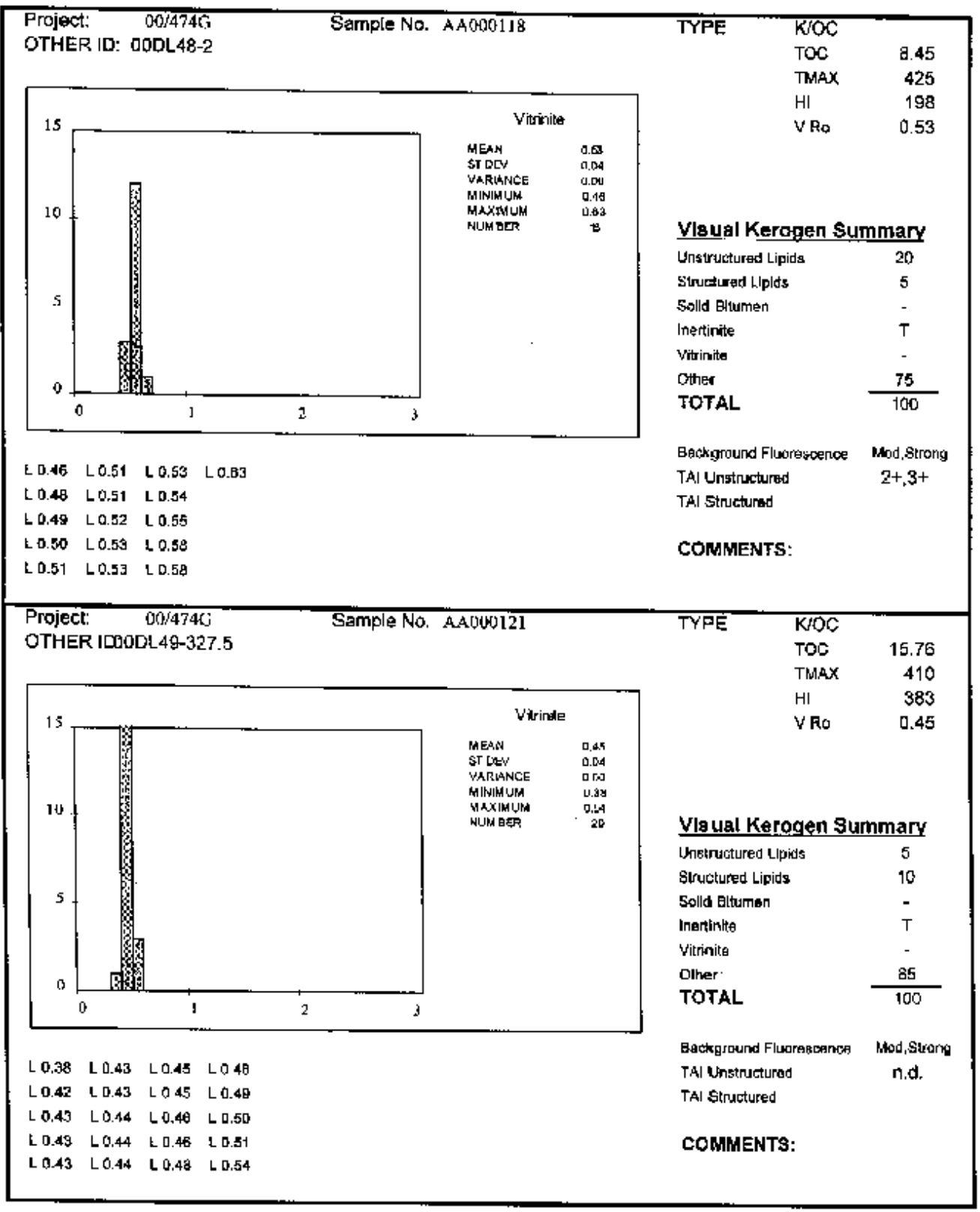


VITRINITE REFLECTANCE

FOOTHILIS PROJECT

HOLITNA DASTY

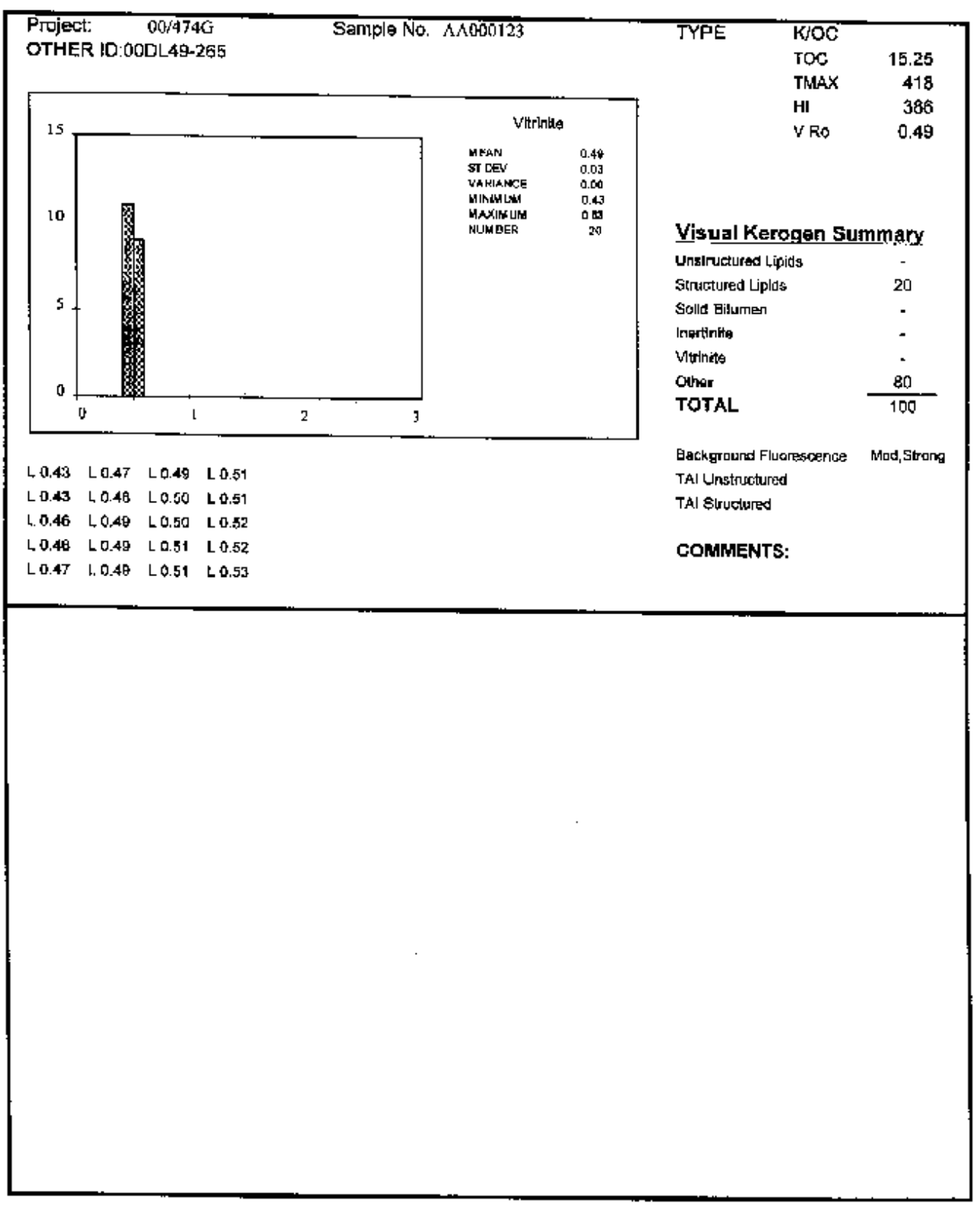




\section{GAS CHROMATOGRAPHY High Resolution Capillary GC (HRCGC)}

\section{Techniques and Parameters}

High Resolution Capillary Gos Chronitography (HRCGC) is atr analytical technique ortich is used

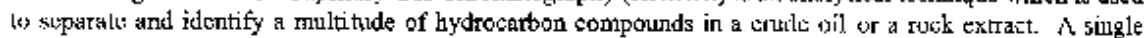

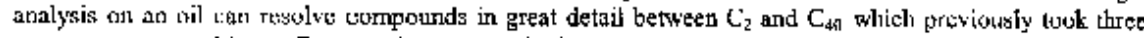

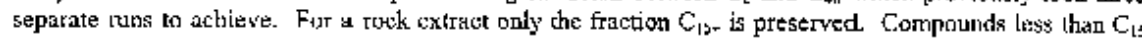
are partially lost during extaction. Key compoumis ars idintifod and ratios calculated which are then used to interpret the kerogen type, organic facies, deposilional onvironnent and themal history in the sourec rocks; the origin, type, themal maturity and other alteration cffects including water wastjug:

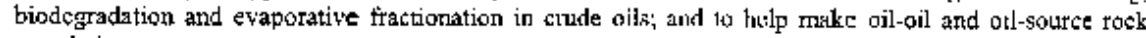
t:orTlualions.

\section{Whole Extrutt Gus Chromatography}

Aburu 50 grams of sample are crushed, pased through a 20 micrun sieve, accurately weighet ard

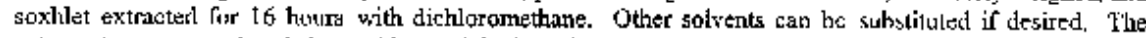
solvent is evaporated and the residuo woigher to obtain the weighe perent of tntal organic exlract. The advantage to doing whole extract slirmirthgersphy is that more of the lighter fraction $\left(\Gamma_{10}-C_{15}\right)$ is

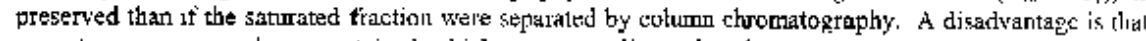
nonsaturate compounds are retained which may complisate the shromptogram. liortentitely, this is a problem only in sone relarively immature extacts. $A$ sample of while extract is injected directly into a gas

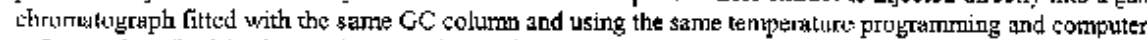

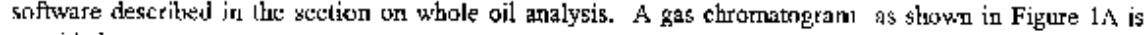
provided.

Whole exrract gas chromatograpty provides infontration on the organic facits and themal

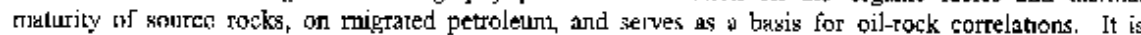
recontrented frimarily tri evaluate known or stspected source beds, wil shows, samples with anomalous pyrolysis $S_{1}$ values and tro idertify prossible contaminarion products.

\section{Aromatic GC}

Higlı Pressure I.iquich Chromatography is used to prepare als amonalic frattion which is then

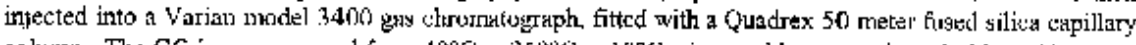

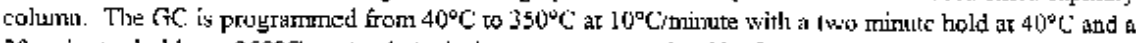
20 reinule hwld at $350^{\circ} \mathrm{C}$. Analycical data are procensed with Grnie Software Systentio and HP Chemintation dhen ncepuisition software. This sofware system tacilitates da14 processing and grapaic display as urel] as electronil dala transmissiun. Thinty-three aromatic bydrocarbons are separalod and detected and these are broken dowr intri six w turnalic hydrocarbon types.

\section{Wholc Oir GC}

A sample of whole oil is injecled directly into a Varian model 5400 gas chromatobapt filled with a Quadrex 50 meter tused silica capillery columin. The GC is progranunged from 40 to $350^{\circ} \mathrm{C}$ at $10^{\circ} \mathrm{C}$ minute with a 2 minute bold at $40^{4}$ and a 20 minute hold at $35 \mathrm{fr}^{\circ} \mathrm{C}$. Analytical data are processed with Gerie Solhware System and IIP chemstation data acquisition software. This software sysem tacilitates daca proncessing ant yraphic display as well as electronie data transmittal. All standard calculations arte thide including prislaneiphylante ratio, carbon preference index, and other key parartulers (Tables 1 and 2). 'lwo

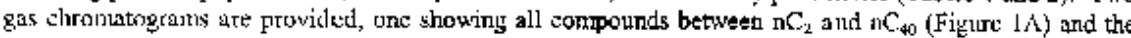
other a computer erihisl-erl wersion of the chrornatogran between $\mathrm{nC}_{2}$ and $\mathrm{nC}_{10}$ (Figure $1 \mathrm{~B}$ ). Compounds as low as ethane can be detected if present. In addition, the concentranot of $C_{1.5}$ to $C_{20}$ istpprtuoids are determuned and plotred (see example of standlaril reporl'). 


\section{Whole Oil Light Ends: Compound Identification}

\begin{tabular}{|c|c|c|}
\hline$\underline{\text { Nö. }}$ & Abhreviation & Neme \\
\hline 1. & $\boldsymbol{n} \cdot \mathrm{C}$ & Ethate \\
\hline 2. & $n-6$ & Propнпе \\
\hline 3. & $i-C_{4}$ & Isobนสา \\
\hline 4. & $\mathbf{n}-\mathrm{C}_{4}$ & n. Bnıtang \\
\hline 5. & $\mathrm{i}-\mathrm{C}_{5}$ & Esopentane \\
\hline 6. & $n-C_{5}$ & u-Penane \\
\hline 7. & 22DHI & 2,2-Dimetlylbulane \\
\hline 8. & $2 \mathrm{MP}$ & 2-Melbylpentane \\
\hline 9 & 3MP & 3-Methylpentane \\
\hline$* 10$. & $11-C_{0}$ & n-Ilexant \\
\hline 11. & $24 \Gamma \mathrm{MP}+\mathrm{MCP}+22 \mathrm{DMP}$ & $2,2 \& 2,4$ Dimethylpentanc + Methyleyclopentane \\
\hline 12 & $\mathrm{BZ}$ & Bcnzene \\
\hline 13. & CHI & Qpuluhexane \\
\hline 14. & 2WII & 2-Methylhurano \\
\hline 15 & $23 \mathrm{DMT}^{\mathrm{M}}$ & 2.3-Dirmethylponlano \\
\hline lis. & I ] $\mathrm{MMCP}$ & 1, 1 Dinietbyleyclopentane \\
\hline 17. & $3 \mathrm{MH}$ & 3-Yethylhoxate \\
\hline 18. & 1C2DMCH & 1-c-3-Dimethysyclopentare \\
\hline 1.9. & $1 \mathrm{~T} 2 \mathrm{LT} \mathrm{NCP}+3 \mathrm{E}$ & 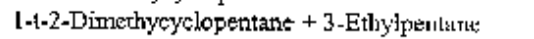 \\
\hline 20 & $1 T 3 D \mathrm{MCP}$ & ]-t-3-IJitethlycyclopentane \\
\hline+21. & $\pi-C$ & n-Heptane \\
\hline 422 & MCH & Methycyclohexane \\
\hline$\neq 23$ & $10 \mathrm{~L}$ & Toluetie \\
\hline+24 & $\mathrm{~L} \cdot \mathrm{C}_{\mathrm{B}}$ & n-Ortane \\
\hline$* 2,3$ & $n-C$ & Il-Nunanc \\
\hline *2G. & $1-C_{10}$ & ni-Dectarat \\
\hline
\end{tabular}




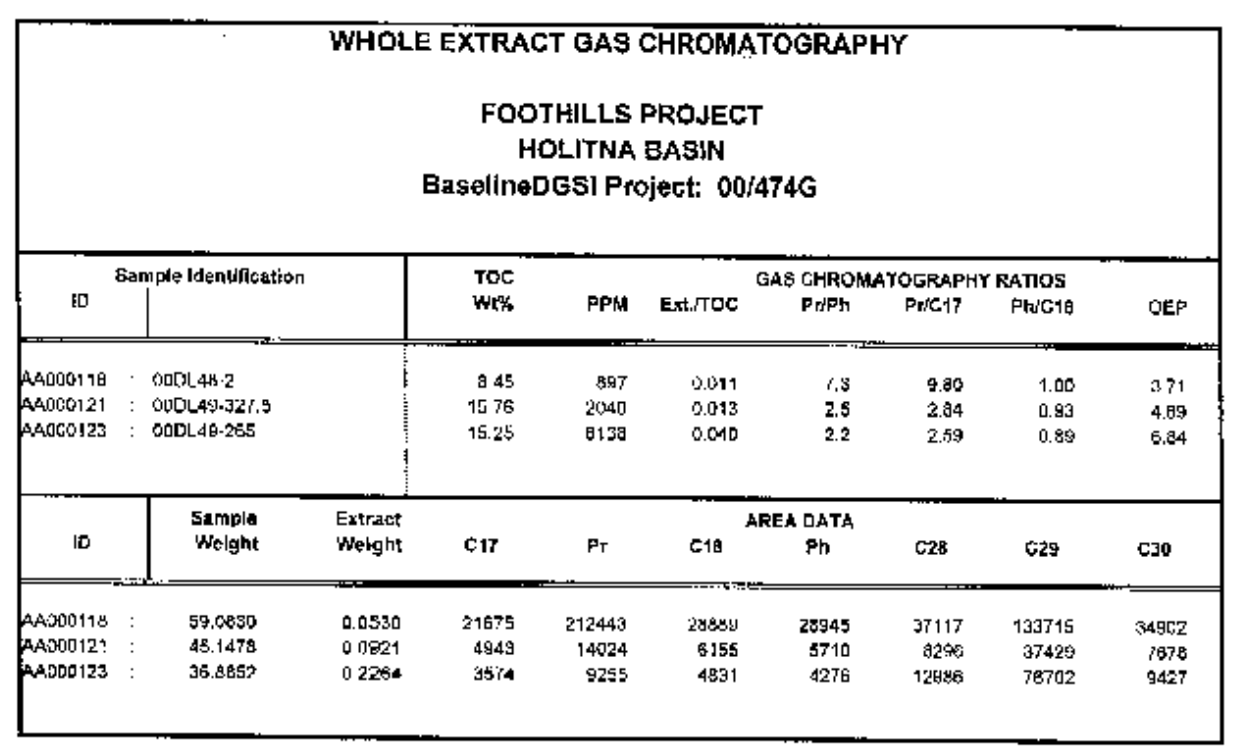

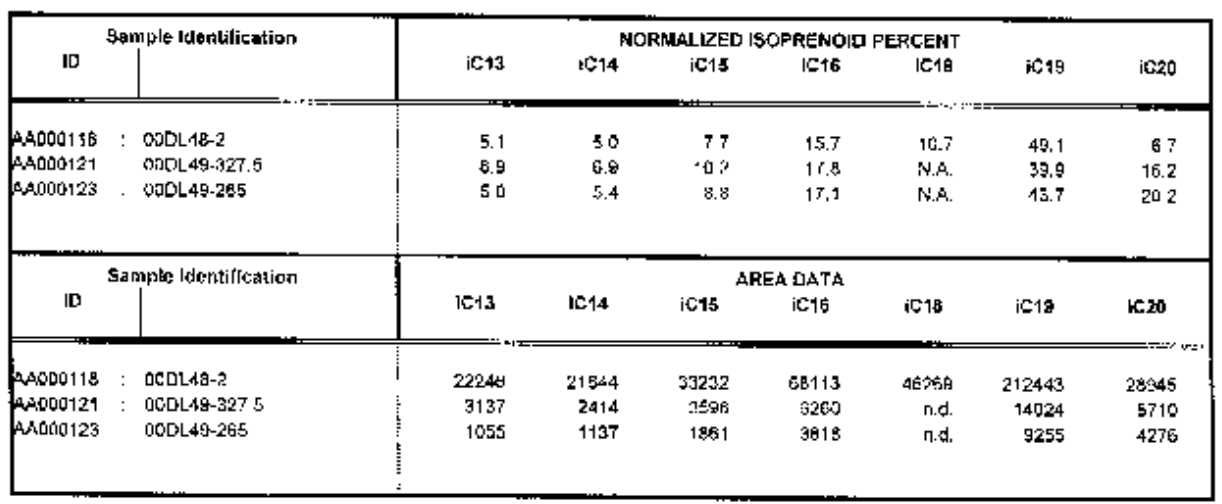




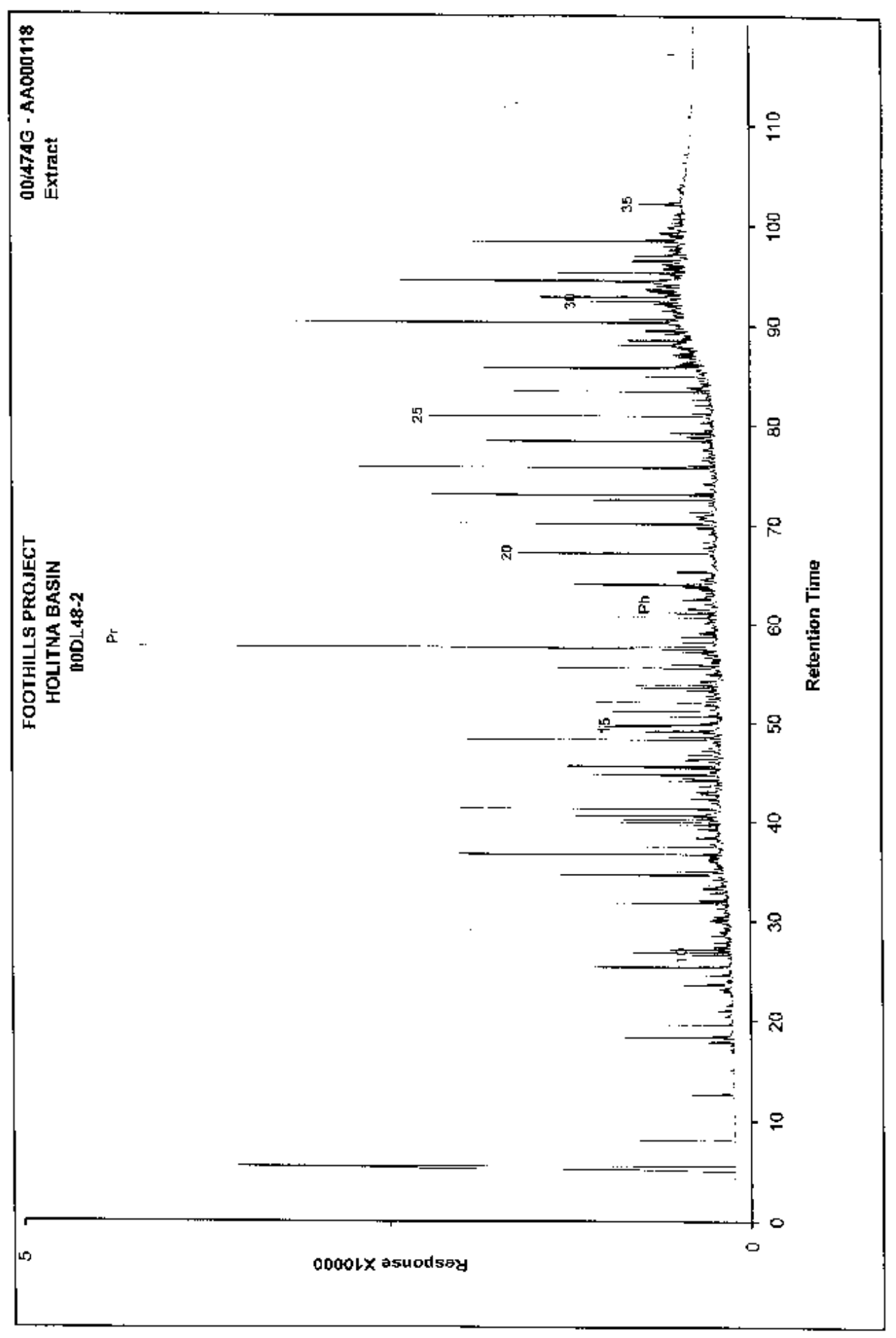




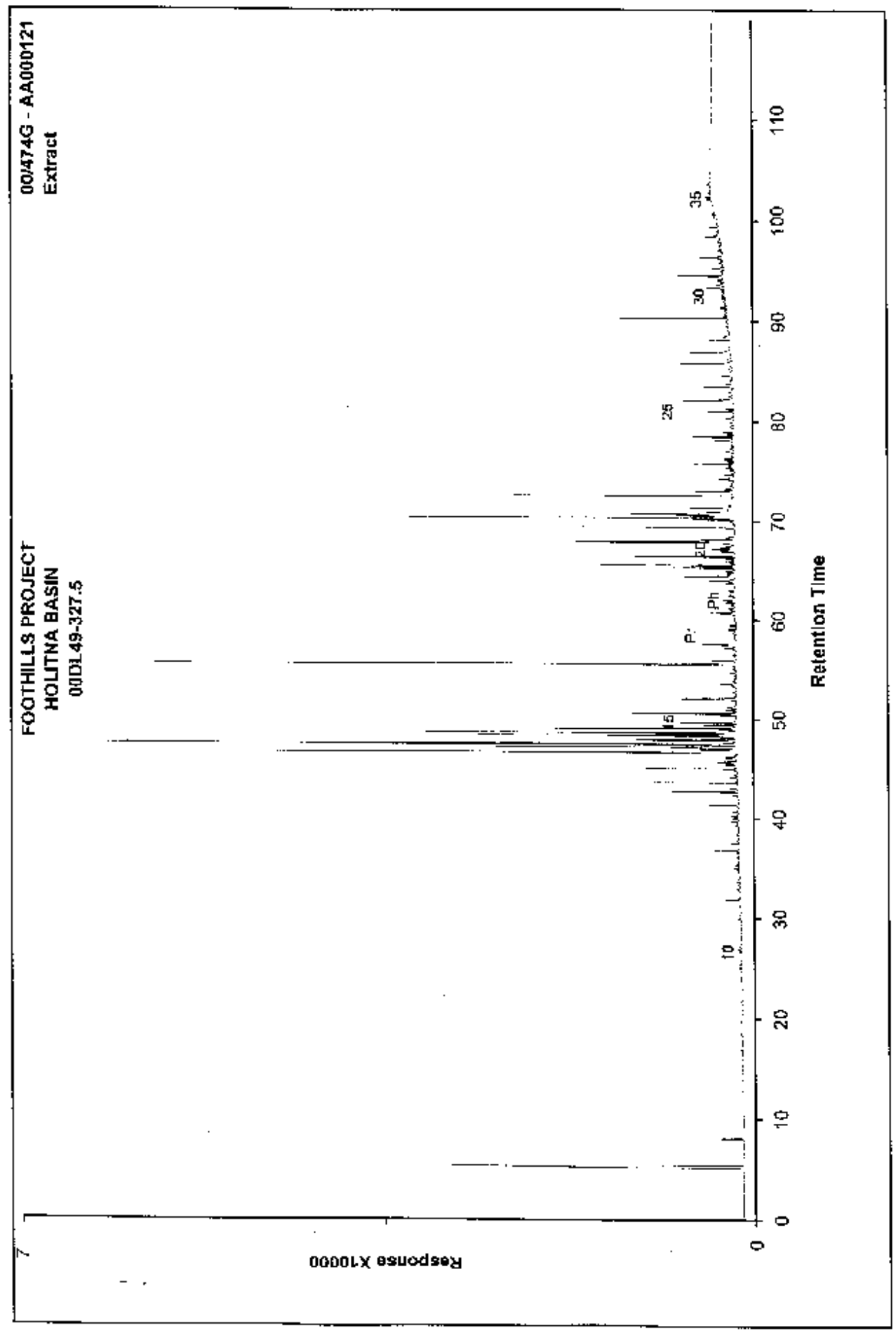




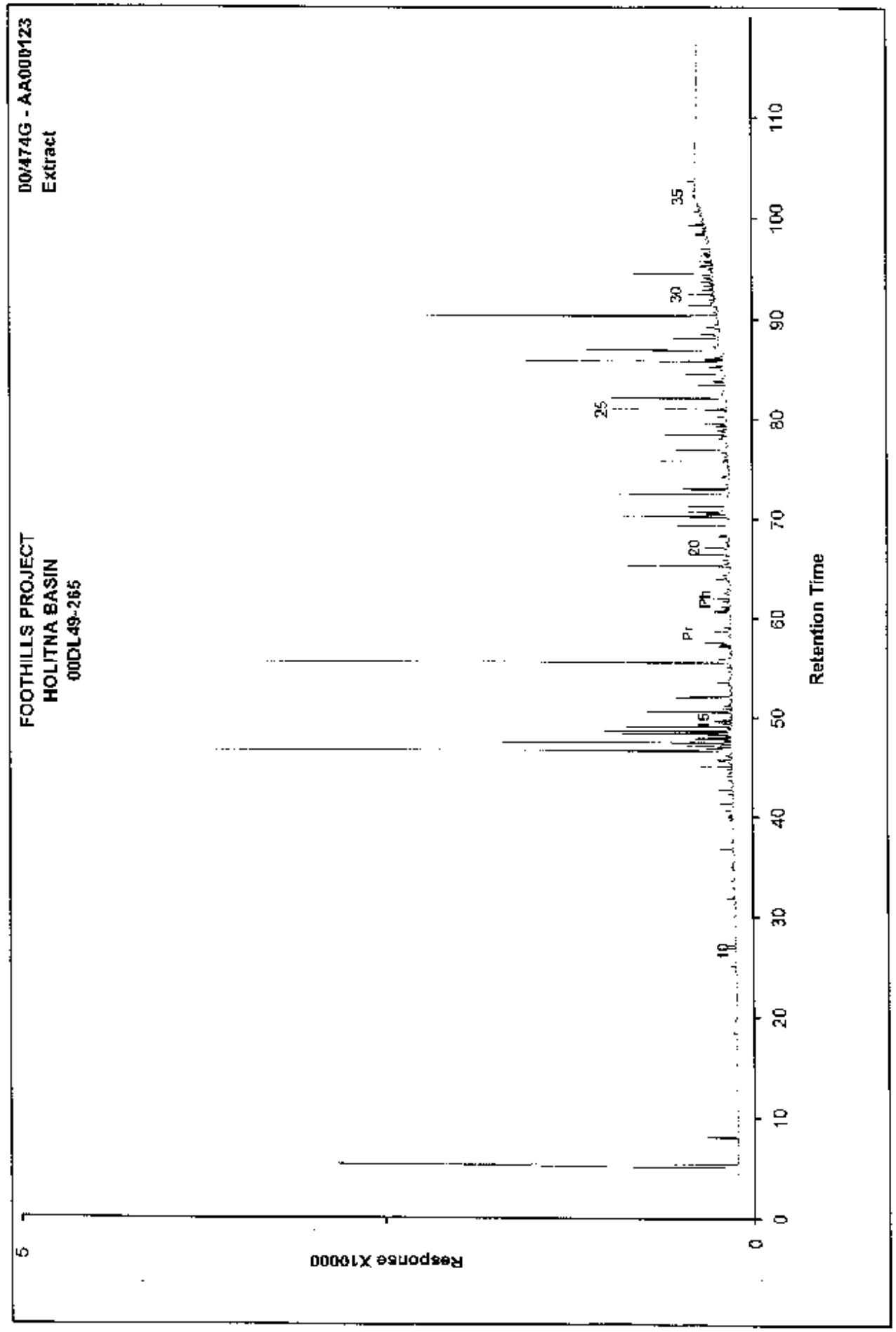




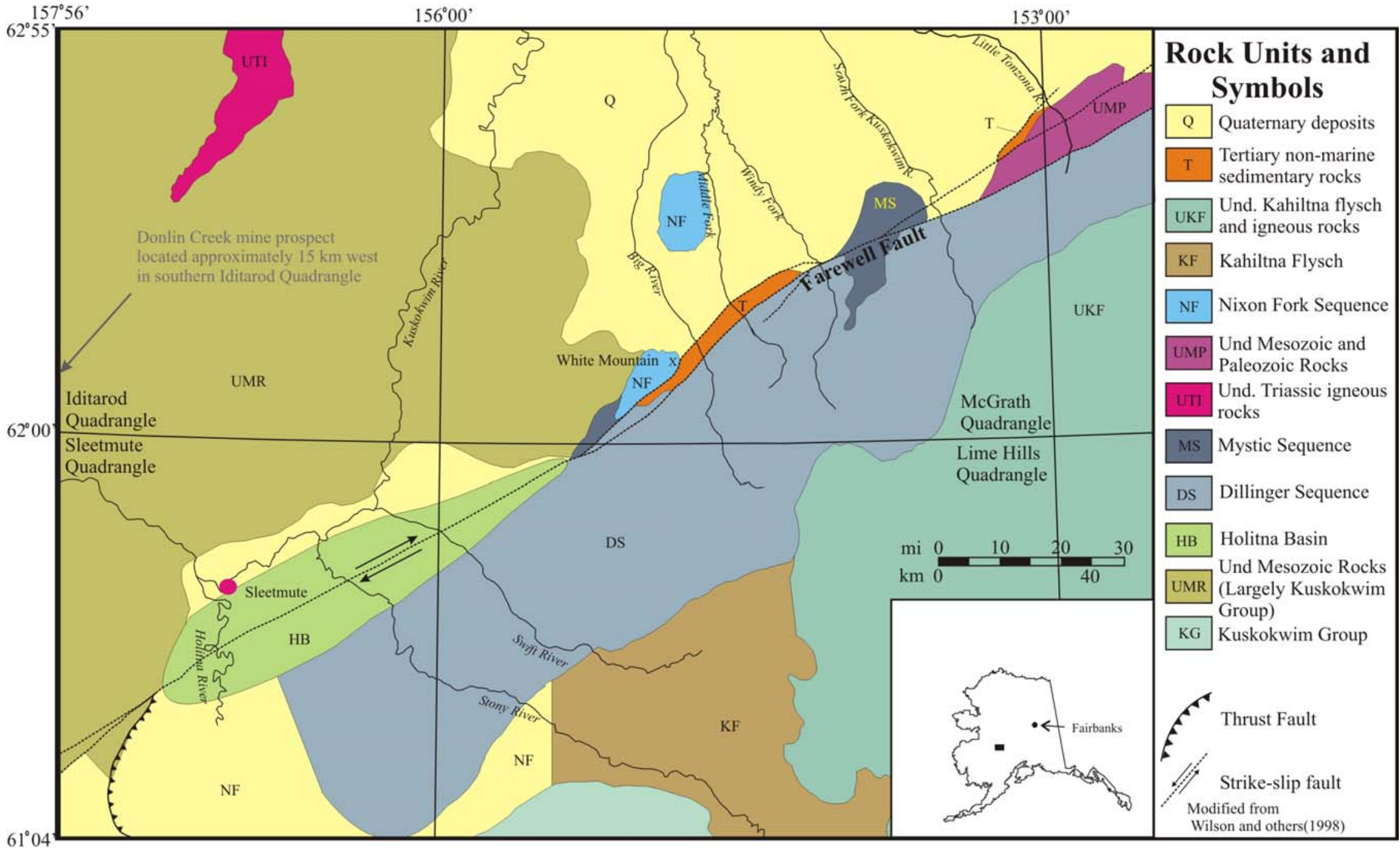

Figure 1. Generalized geologic map of the Holitna Lowland region, Sleetmute and Lime Hills quadrangles, and the Tertiary outcrop belt in southern and central McGrath Quadrangle. 


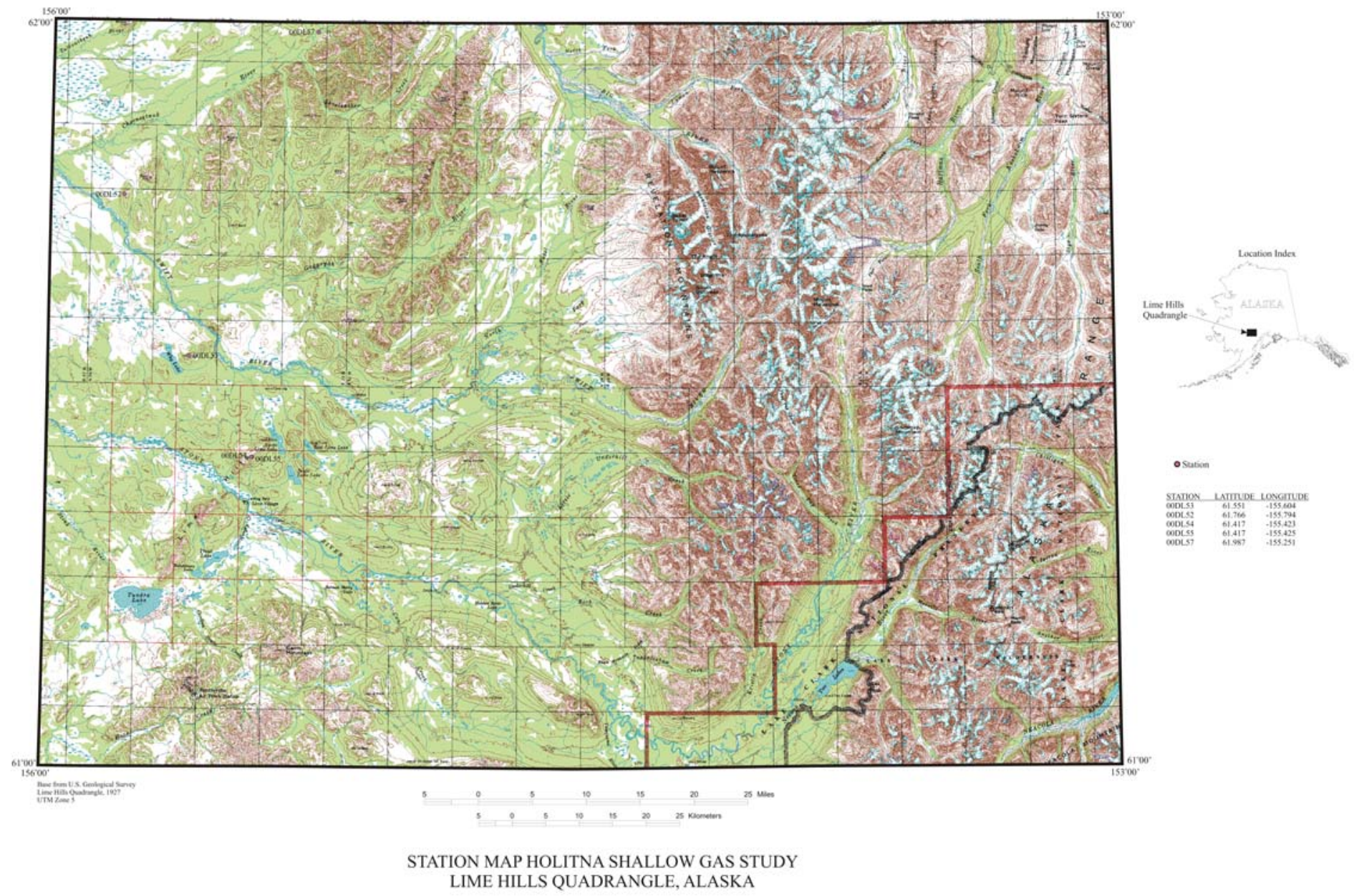

Figure 2a. Map showing sample locations in the Lime Hills Quadrangle. Locations 00DL52 through 00DL55 are in Paleozoic strata and are not discussed in the text. Location 00DL.57 is the southwestern-most

exposure of Tertiary strata examined in this study. No additional exposures of Tertiary strata are known along the Cheeneetnuk River southwest of this location. 


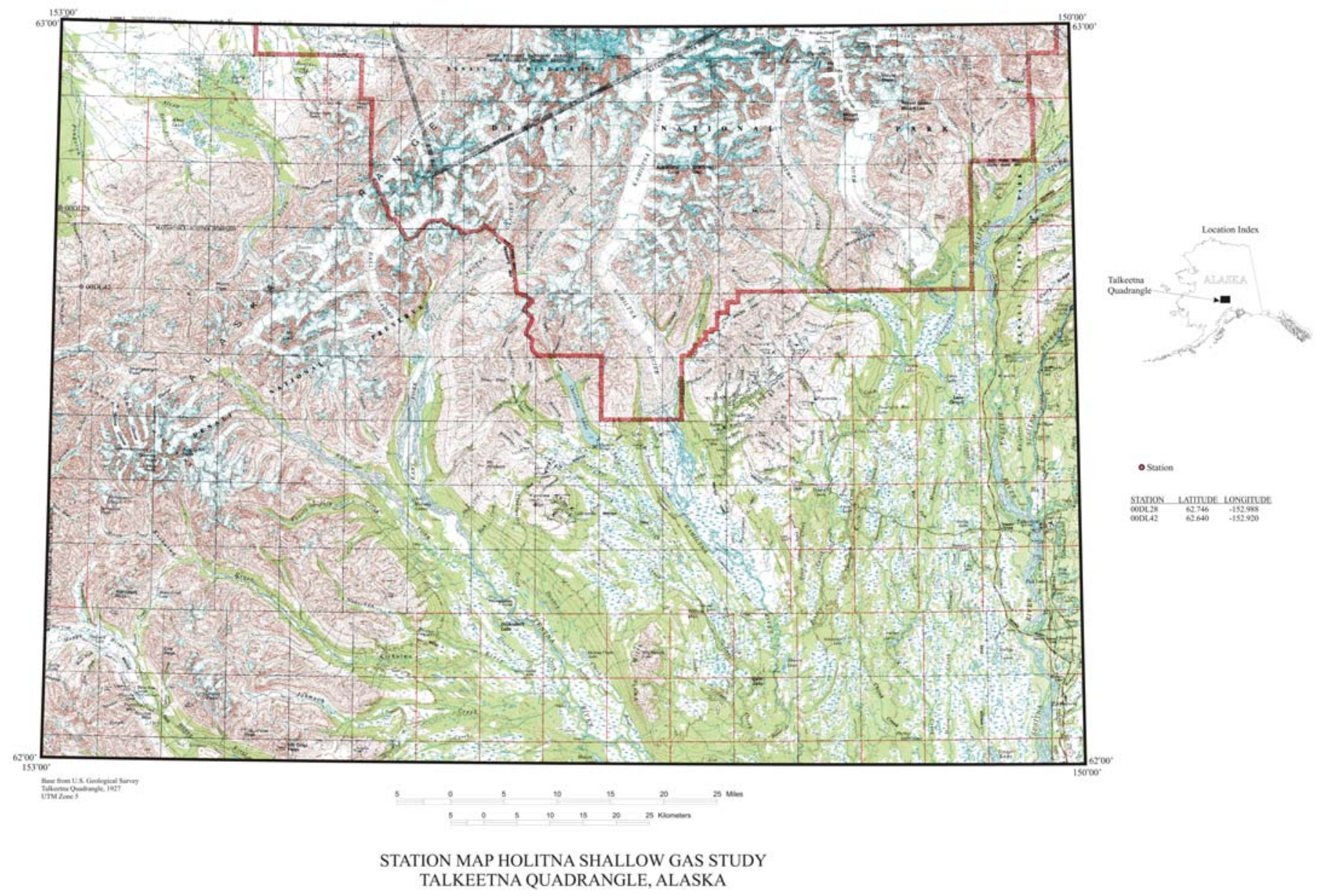

Figure 2b. Map showing sample locations in the Talkeetna Quadrangle. Location 00DL28 is the northeasterm-most exposure of Tertiary strata examined in this study. Location 00DL42 is not discussed

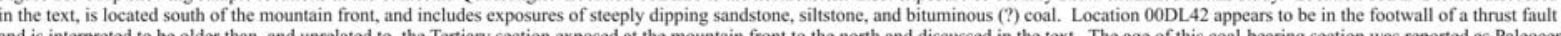
by Reed and Nelson (1980)- 
LLASKA DIVISION OF GEOLOGICAL.

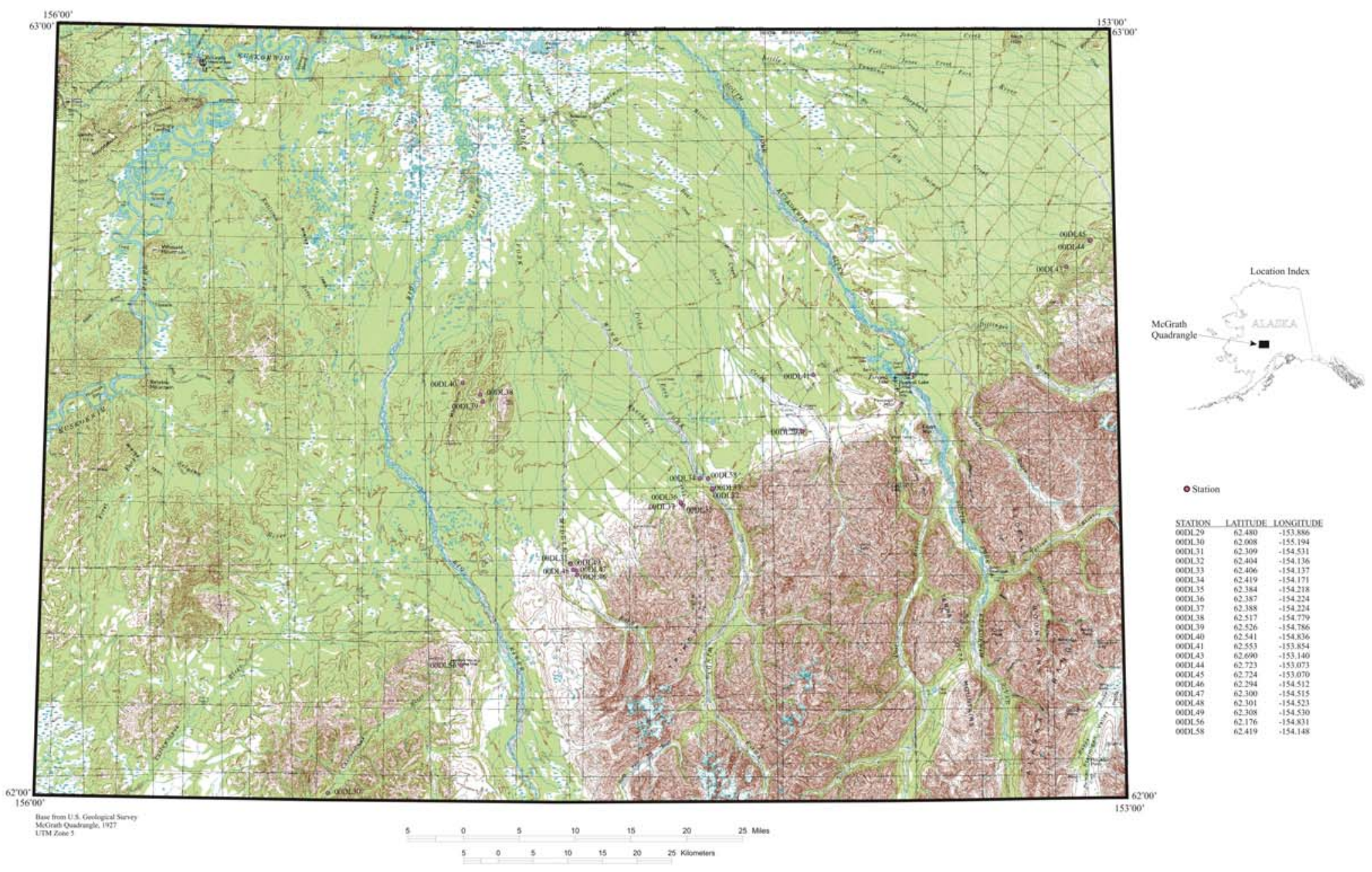

STATION MAP HOLITNA SHALLOW GAS STUDY

MCGRATH QUADRANGLE, ALASKA

Figure 2c. Map showing sample locations in the McGrath Quadrangle. Locations 00DL38 through 00DL40 include exposures of Proterozoic and lower Paleozoic strata and are not discussed in the text 


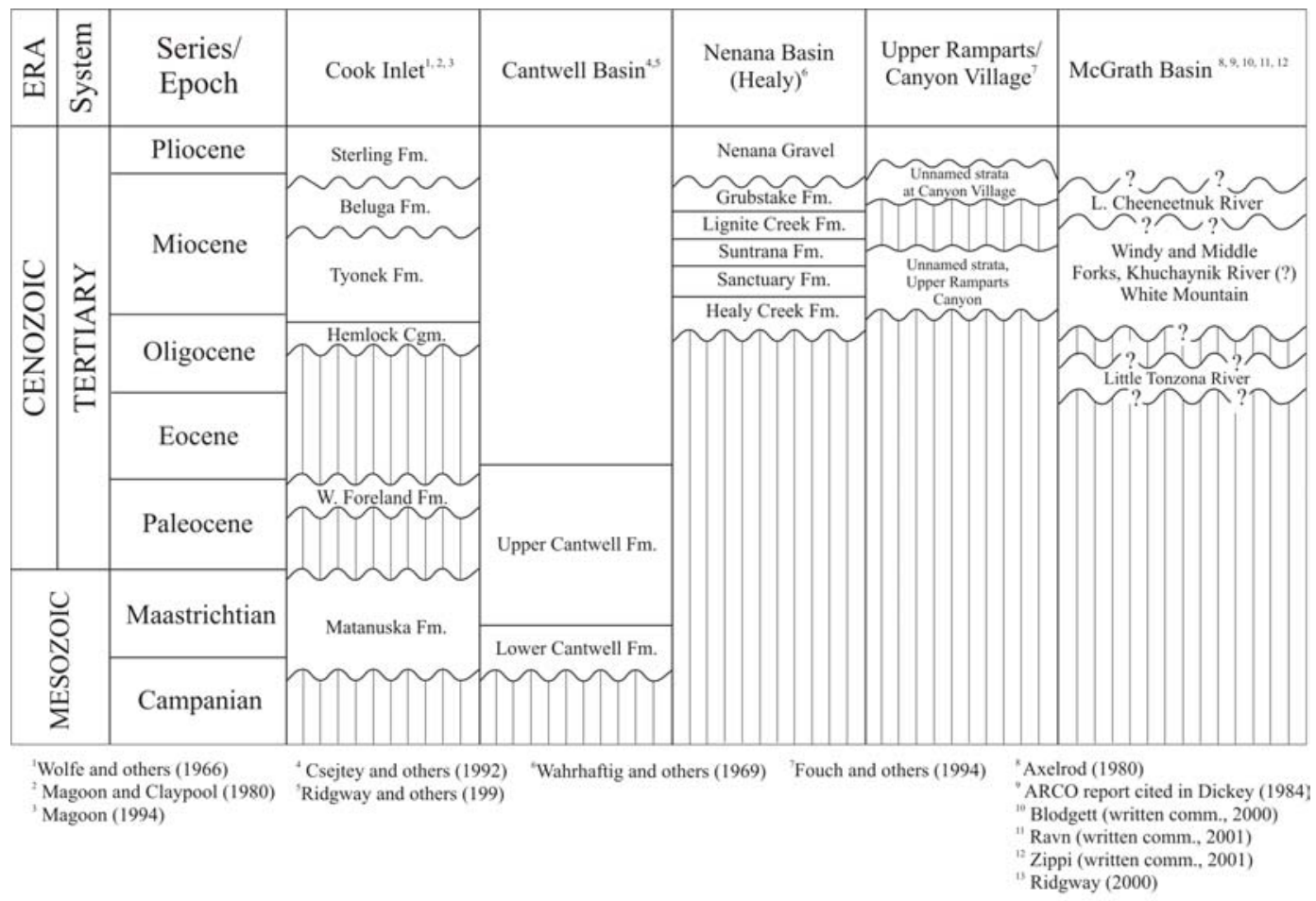

Figure 3. Correlation of Tertiary stratigraphic units in southwest, central, and south-central Alaska. 

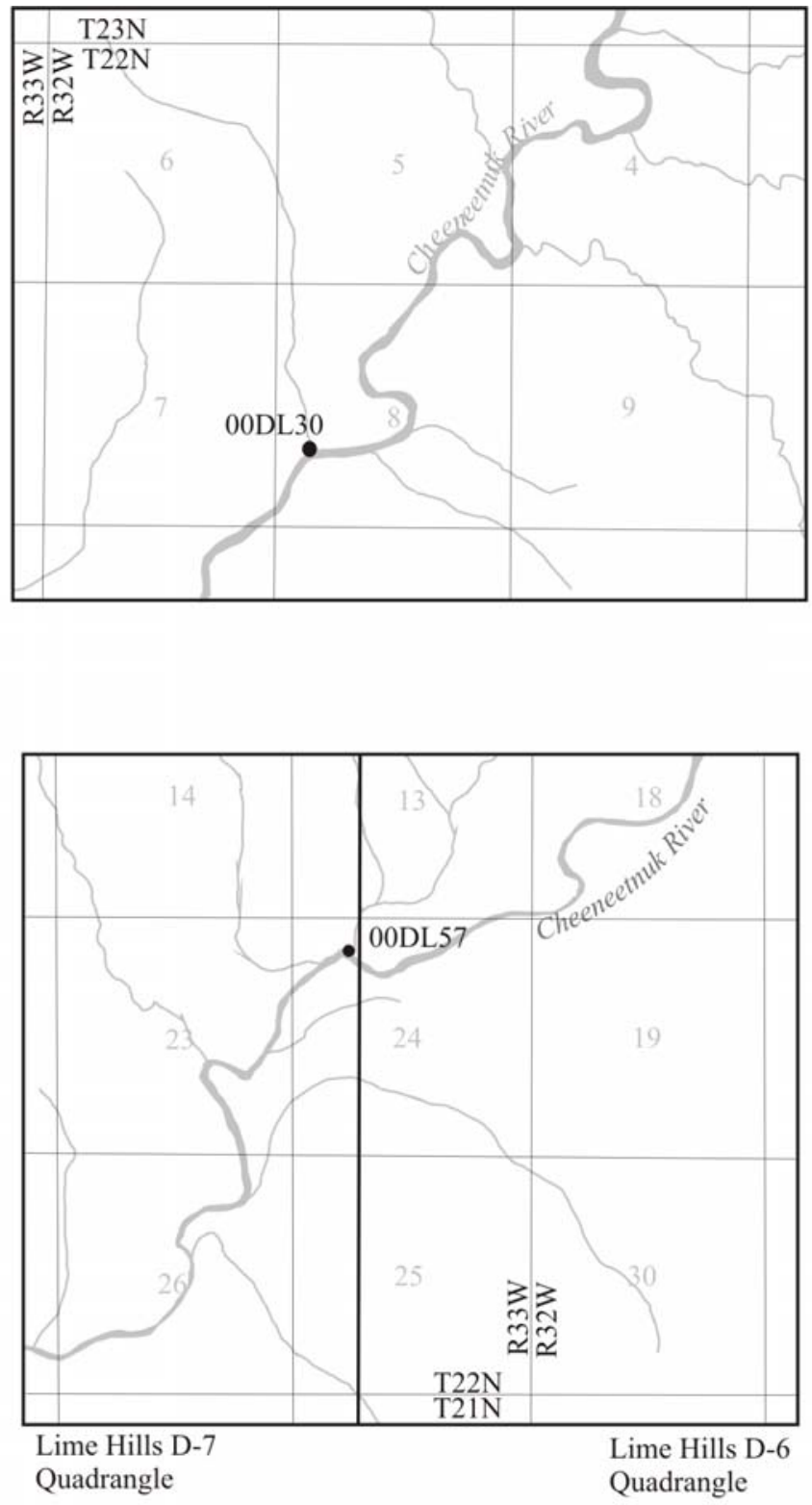

Figure 4. Map showing the locations of small exposures on the banks of the lower Cheeneetnuk River in the McGrath A-5 and Lime Hills D-7 quadrangles. Both exposures are located on the north bank of the river. See Gilbert (1981) for geologic map showing these exposures. 


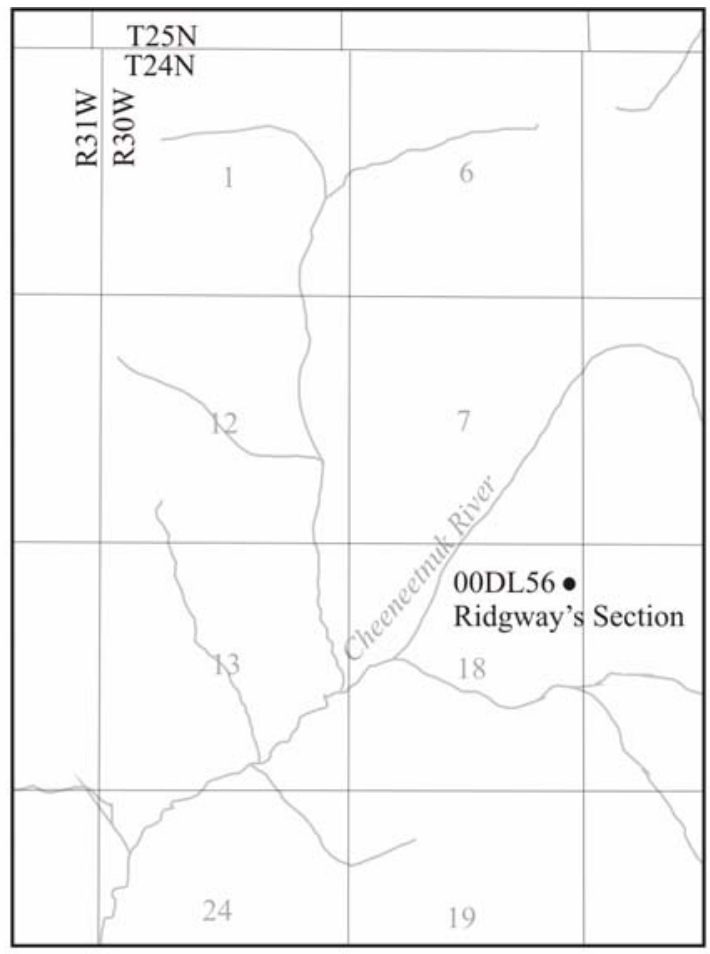

Figure 5. Map showing the approximate location of section measured by Ridgway and others (2000), McGrath A-4 Quadrangle.

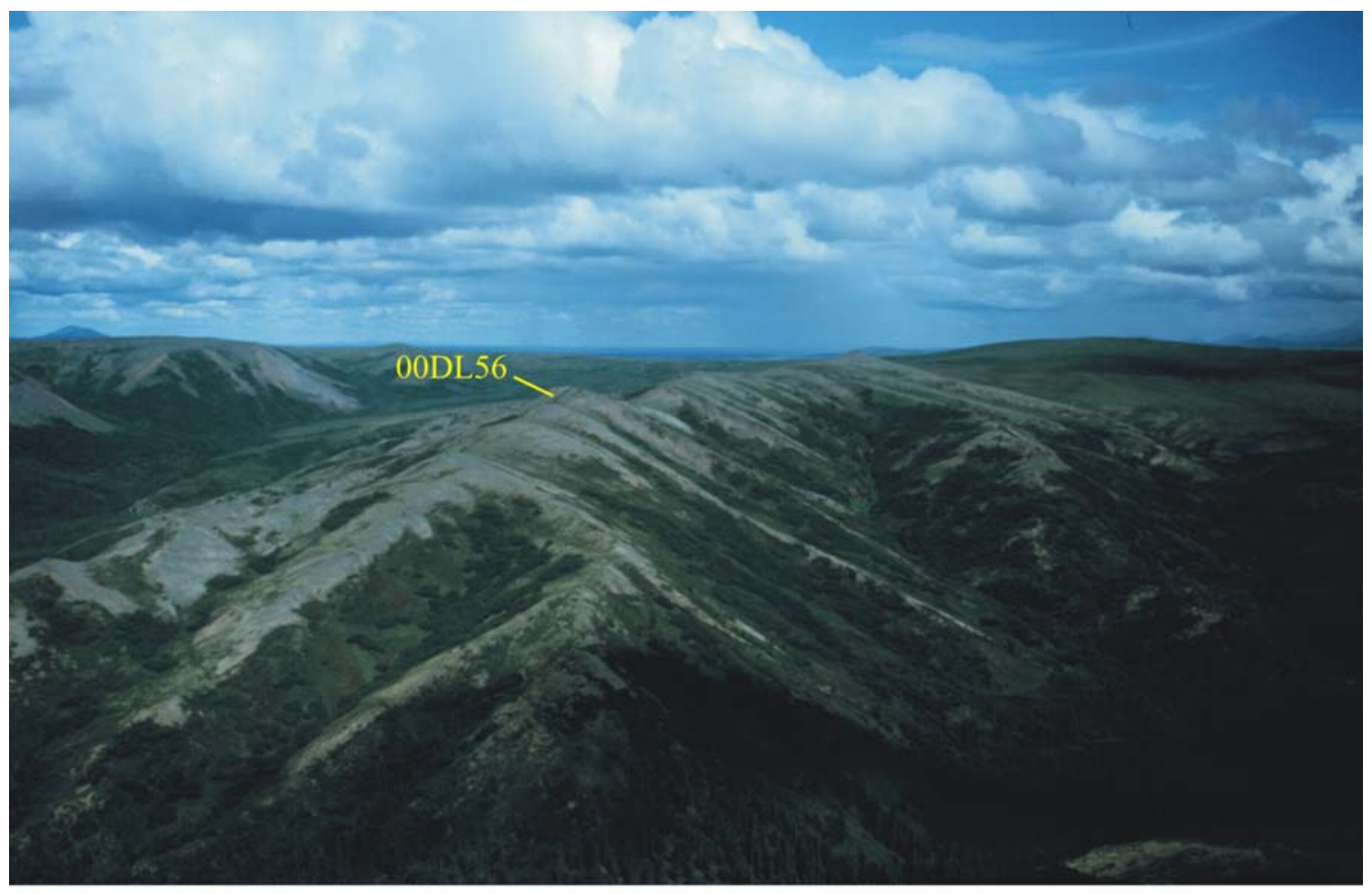

Figure 6. Helicopter view of the southeast dipping Tertiary section immediately south of White Mountain, southwestern McGrath Quadrangle. View toward the northeast. Light gray and white material is pebble conglomerate and minor interbedded sandstone. 
A.

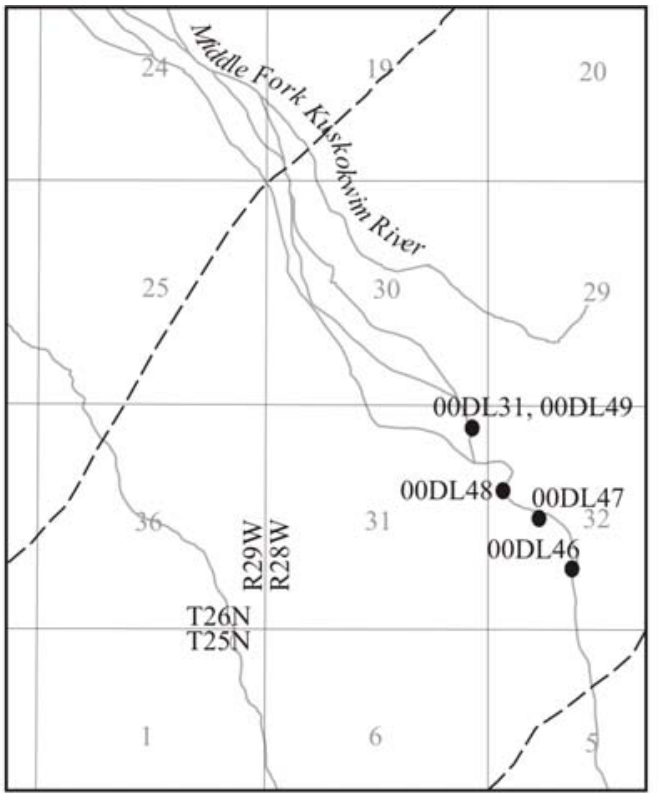

B.

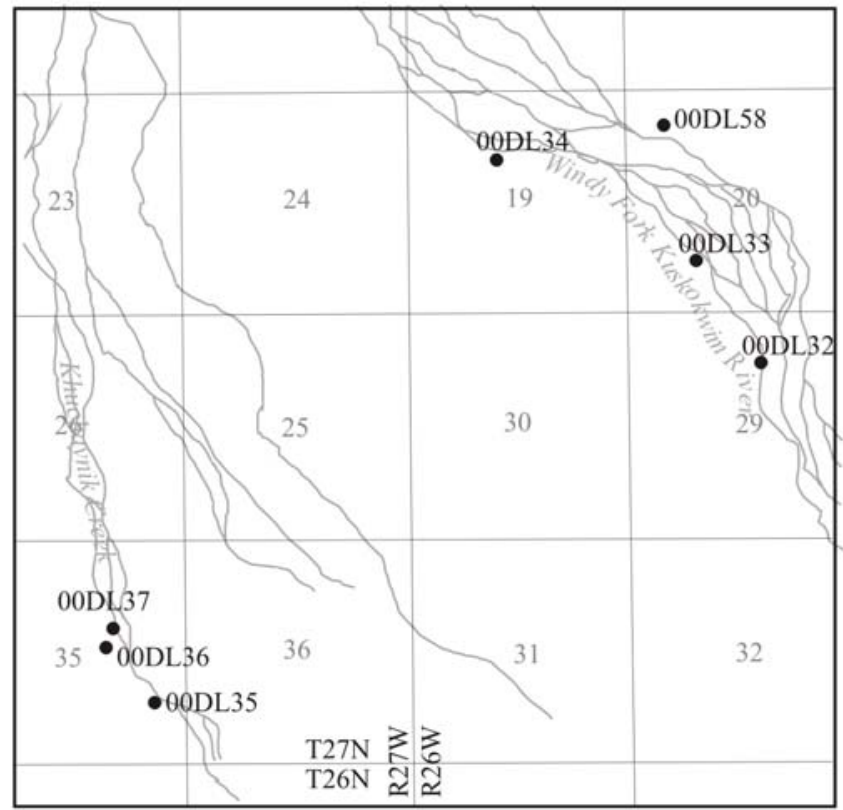

Figure 7: A. Map showing station locations along the Middle Fork of the Kuskokwim River, McGrath B-4 Quadrangle. A short section through a portion of the Tertiary section was measured at 00DL48 (see Fig. 8a). A longer $(345 \mathrm{~m})$ section was measured at 00DL49 (see Fig. 8b). The location of the base of each section is provided in figures $8 \mathrm{a}$ and $8 \mathrm{~b}$. B. Map showing station locations along the Windy Fork of the Kuskokwim River and the Khuchaynik River, McGrath B-3 Quadrangle. 
00DL48 Middle Fork, west bank

$62^{\circ} 18.08^{\prime} \mathrm{N}$ Latitude $154^{\circ} 31.36^{\prime} \mathrm{W}$ Longitude

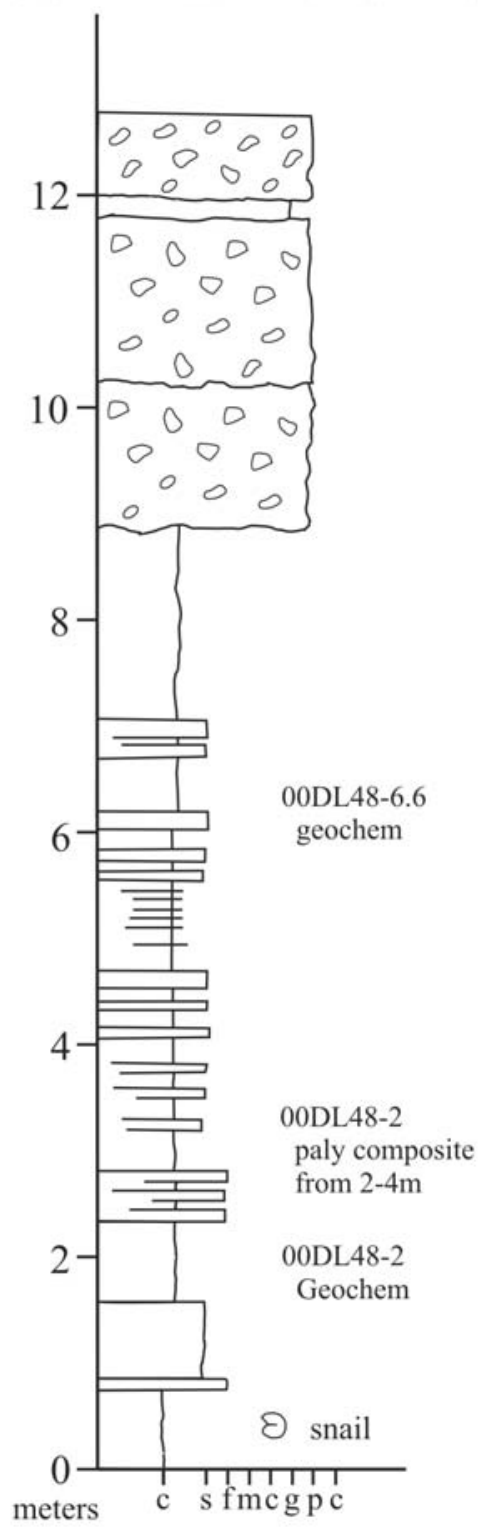

Buff to tan weathering conglomerate body approximately $10 \mathrm{~m}$ thick. Deposited in lowsinuosity, bedload-dominated fluvial setting. Contact with underlying mudrocks is result of channel avulsion and associated erosion.

Dark-brown weathering silty claystone with thin interbeds of siltstone and very fine sandstone. Dimunitive snails and bivalves in clayey lithologies. Bivalves range from $4-5 \mathrm{~mm}$ across and are unornamented. Swamp adjacent to active fluvial channel belt. Possible distal levee deposits interstratified with perennial flood basin mudstones.

Poorly preserved plant megafossils; betulaceans (willows and alders). Proximal to distal levee transition?

Thick conglomerate bodies are present a few meters downsection, along west bank of the river.

Measured by D. LePain, July 2000

Figure 8a. Measured section of probable middle Miocene strata from the west bank of the Middle Fork of the Kuskokwim River in McGrath B-4 Quadrangle. The succession shown is located at least a few hundred meters down-section from the thick mudstone deposits shown in Fig. 8b. 


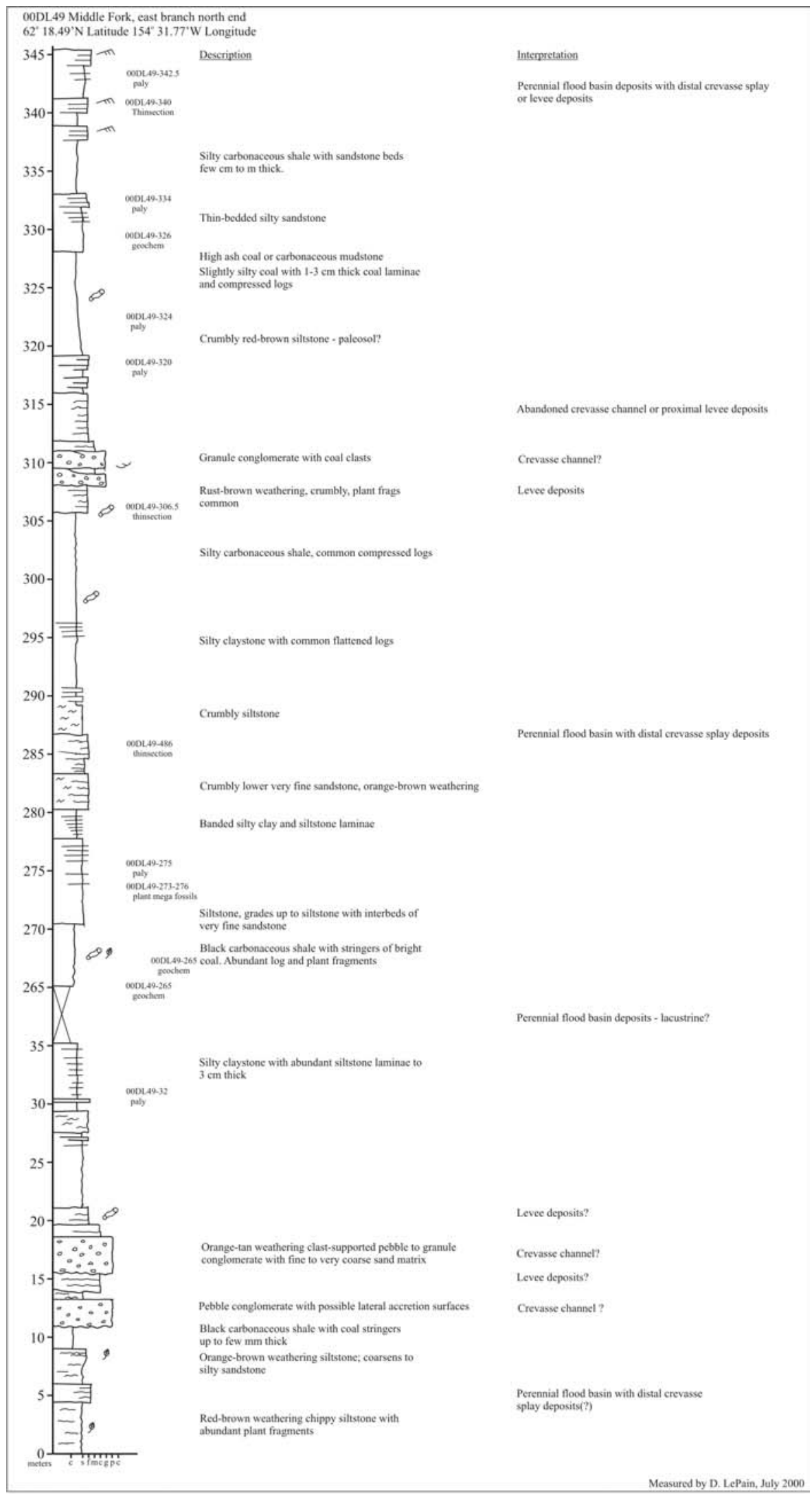

Figure $8 \mathrm{~b}$. Measured section through probable middle Miocene strata exposed on the east bank of the Middle Fork of the Kuskokwim River, in McGrath B-4 Quadrangle. Section is located at the northern outcrop limit of Tertiary strata, at least a few hundred meters up-section from the succession shown in Fig. 8a. 


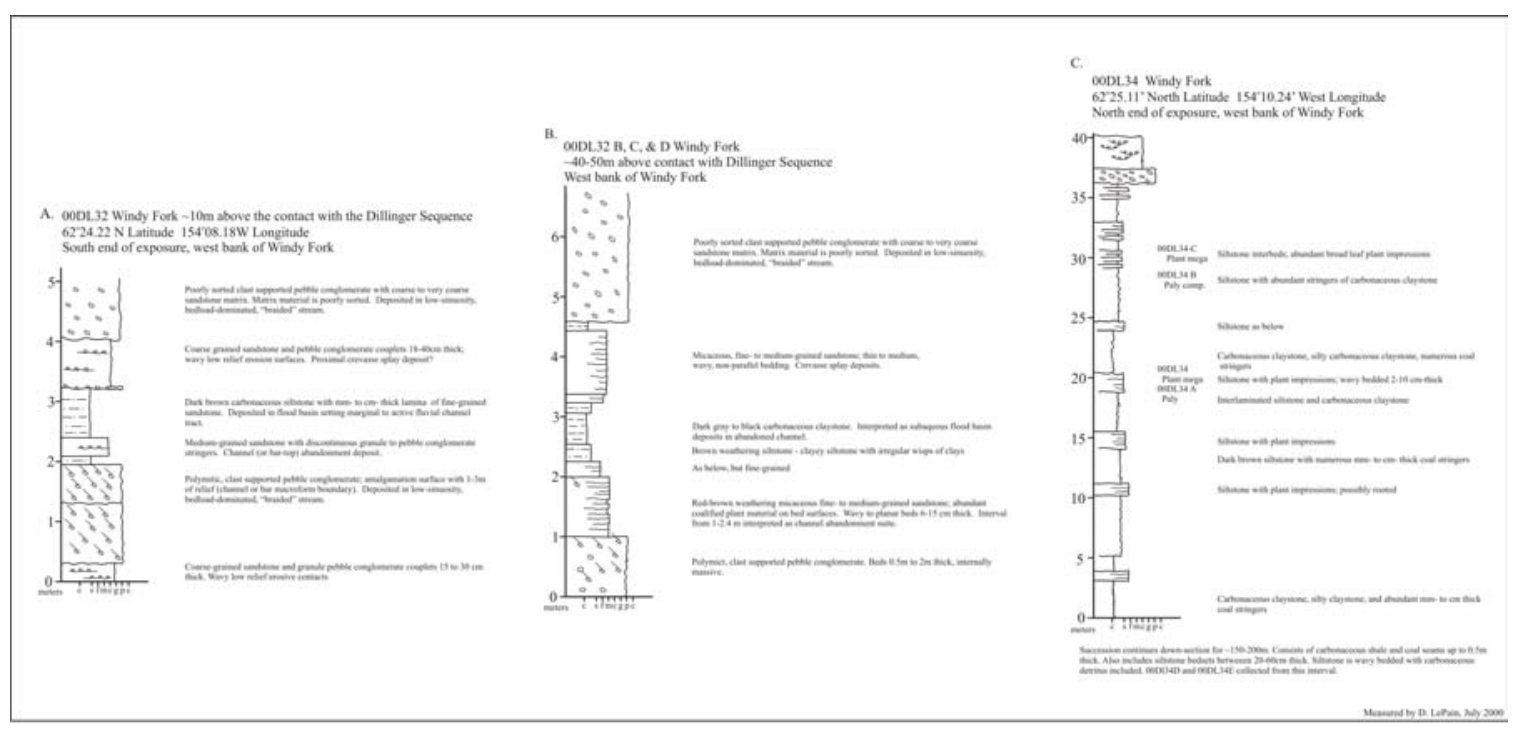

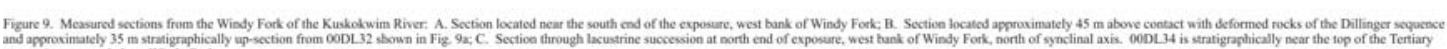
succession exposed dlong Windy Fork. 

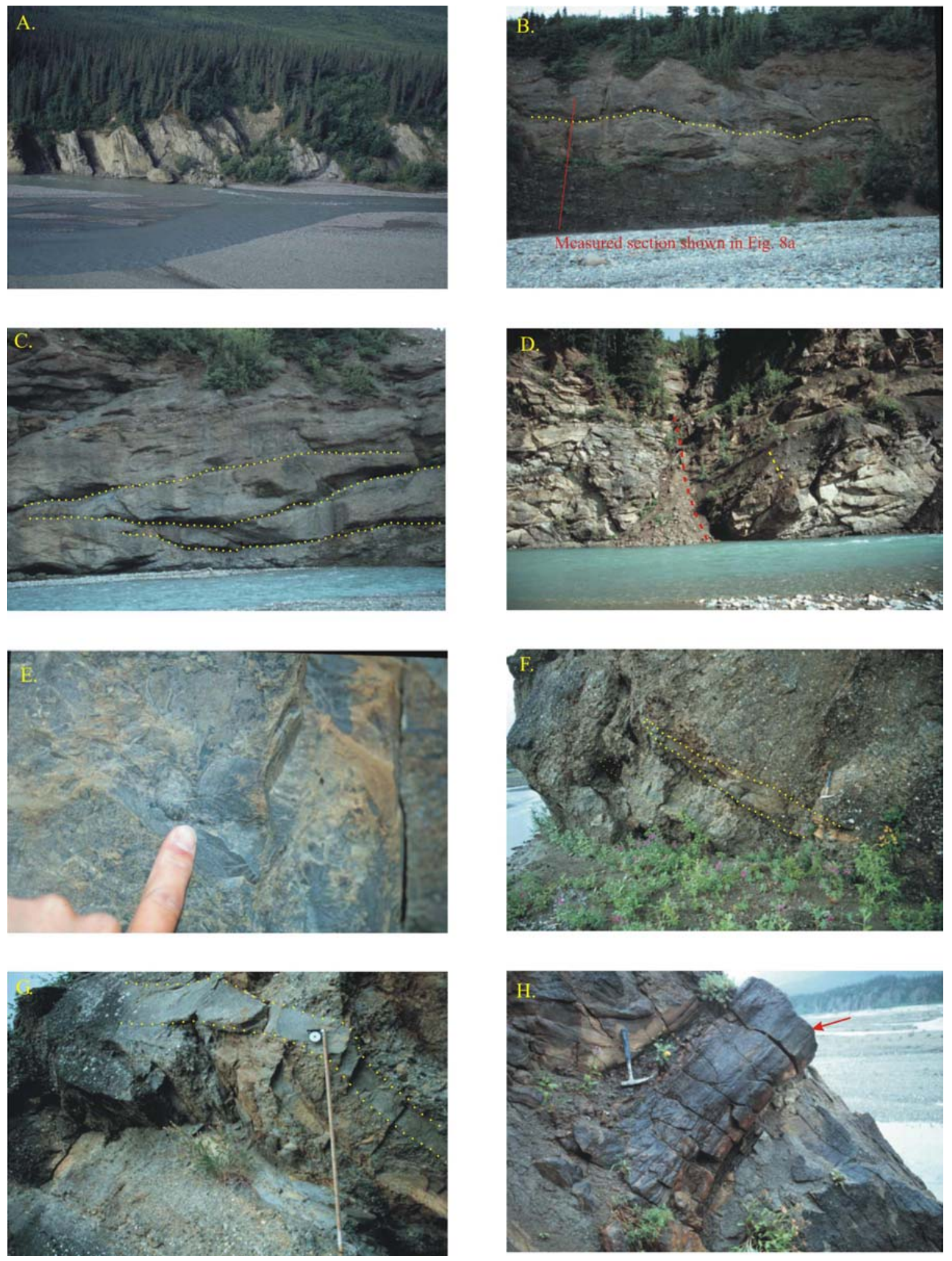

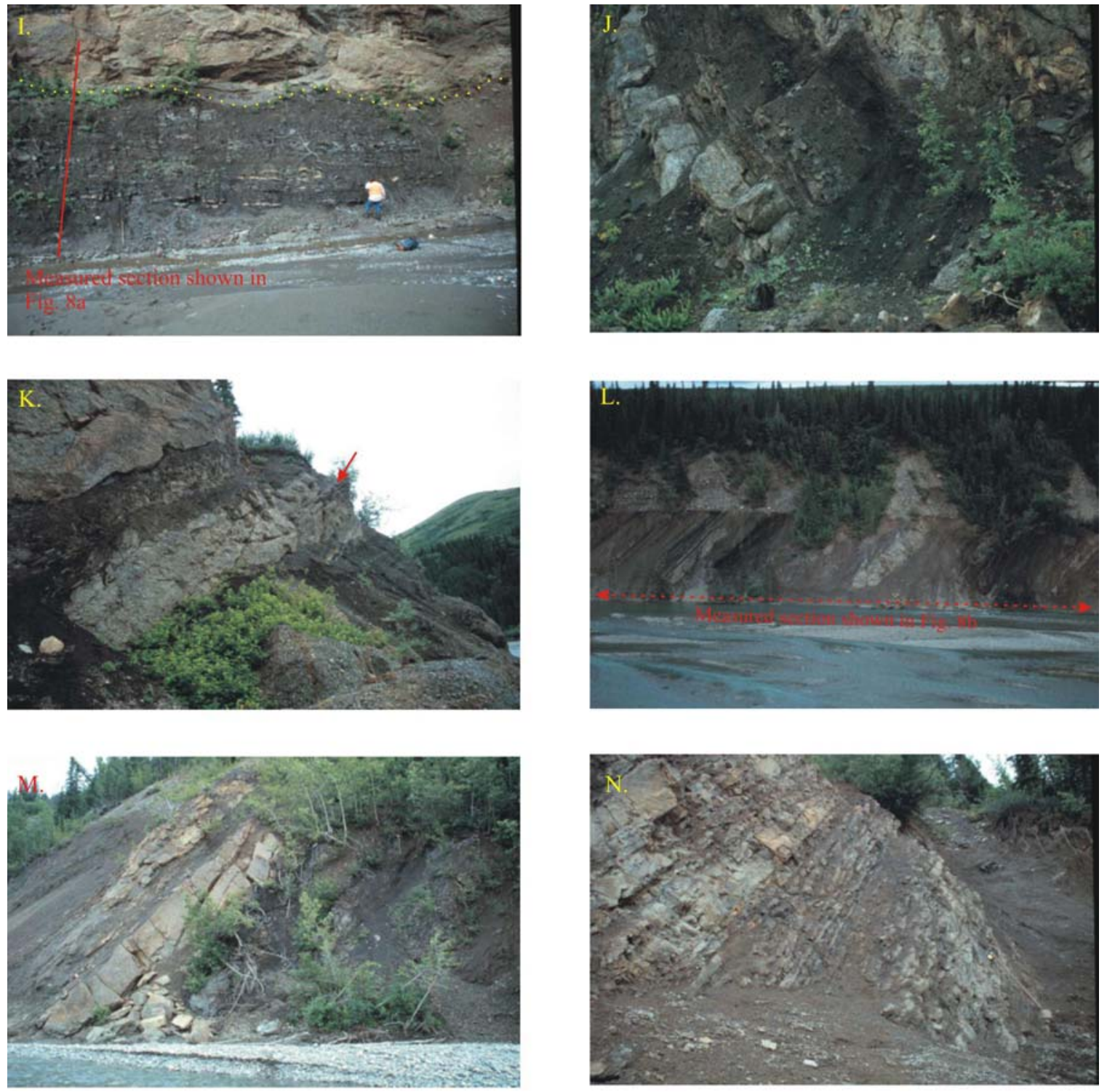
Figure 10. Selected photographs of the Tertiary section exposed on the Middle and Windy forks of the Kuskokwim River. A. Interbedded conglomerate-sandstone and mudstone packages exposed on the west bank of Windy Fork. Bedding is near vertical and stratigraphic up is toward the right (north). Approximately $100 \mathrm{~m}$ of section is shown. Succession shown in photograph is located midway between 00DL32 and 00DL34; B. Amalgamated conglomerate bodies above a thin lacustrine/flood basin succession at 00DL48, located on the west bank of the Middle Fork. Conglomerate unit visible in photograph is at least $3 \mathrm{~m}$ thick. The vertical red line shows the location of the measured section in Figure 8a; C. Concave-upward erosional scours (dashed yellow lines) between channel and bar macroforms exposed on the east bank of the Middle Fork. Approximately $8 \mathrm{~m}$ of section visible in photograph. Exposure located approximately 1/4-mile downstream (north) of 00DL48 shown in Fig. 10b; D. Channel abandonement succession (dashed yellow line) at 00DL47 located on the east bank of the Middle Fork approximately 0.4 miles downstream (north of) 00DL46. Yellow line is approximately $3 \mathrm{~m}$ long. Dashed red line shows trace of high-angle normal(?) Fault; E. Plant leaf impressions in silty sandstone at 00DL32B, located on the west bank of the Windy Fork. Photograph shows silty sandstone at approximately the $2.3 \mathrm{~m}$ level in the measured section shown in Fig. 9b; F. Sandstone lens in pebble conglomerate near the base of exposures of probable lower to middle Miocene (Seldovian) strata on the west bank of the Middle Fork. Contact between sandstone lens and conglomerate is shown by the dashed yellow line. Note hammer for scale near right center of photograph; G. Sandstone lenses in pebble conglomerate, Middle Fork. Staff is $1.3 \mathrm{~m}$ long; H. Tree trunk (red arrow) on sandstone bed surface, located on the east bank of the Windy Fork; I. Lacustrine succession overlain by pebble conglomerate of fluvial origin located on the west bank of the Middle Fork. This photograph is a close-up view of Fig. 10b that show thin resistant siltstone beds in a silty shale interpreted as lacustrine deposits; J. Carbonaceous mudstone and pebbly sandstone succession between two thick pebble conglomerate bodies. Mudstone and enclosed pebbly sandstone are interpreted as a channel abandonment deposit. Succession corresponds approximatley to the $2 \mathrm{~m}$ to $4 \mathrm{~m}$ interval shown Fig. 9a. K. Mudstone succession with pebble conglomerate interbed (red arrow) exposed on the west side of the Middle Fork. Pebble conglomerate bed is $0.85 \mathrm{~m}$ thick and pinches out approximately $20 \mathrm{~m}$ beyond the left edge of the photo in the silty shales shown in Figs. 8a, 10b, and 10i. The $0.85 \mathrm{~m}$-thick conglomerate is interpreted as a crevasse splay deposit along the margin of a lacustrine setting. Thicker body at the upper left of the field of view is a fluvial conglomerate body; L. Thick carbonaceous mudstone succession exposed on the east bank of the Middle Fork. Bedding dips toward the north. Approximately $150 \mathrm{~m}$ of section is shown. Red arrow points to coarsening-upward package shown in Fig.10n. Fining-upward succession shown in Fig. 10m is located approximately $190 \mathrm{~m}$ down-section, beyond the right edge of the photograph; M. Fining-upward sandstone body with lacustrine succession, 5 to $25 \mathrm{~m}$ interval in measured section 00DL49(Figure 8b), Middle Fork; N. Coarsening-upward sandstone cycle within lacustrine succession, 295 to 309 $\mathrm{m}$ interval measured section 00DL49 (Figure 8b), Middle Fork. Note $1.5 \mathrm{~m}$-long staff in lower right of photograph for scale. 


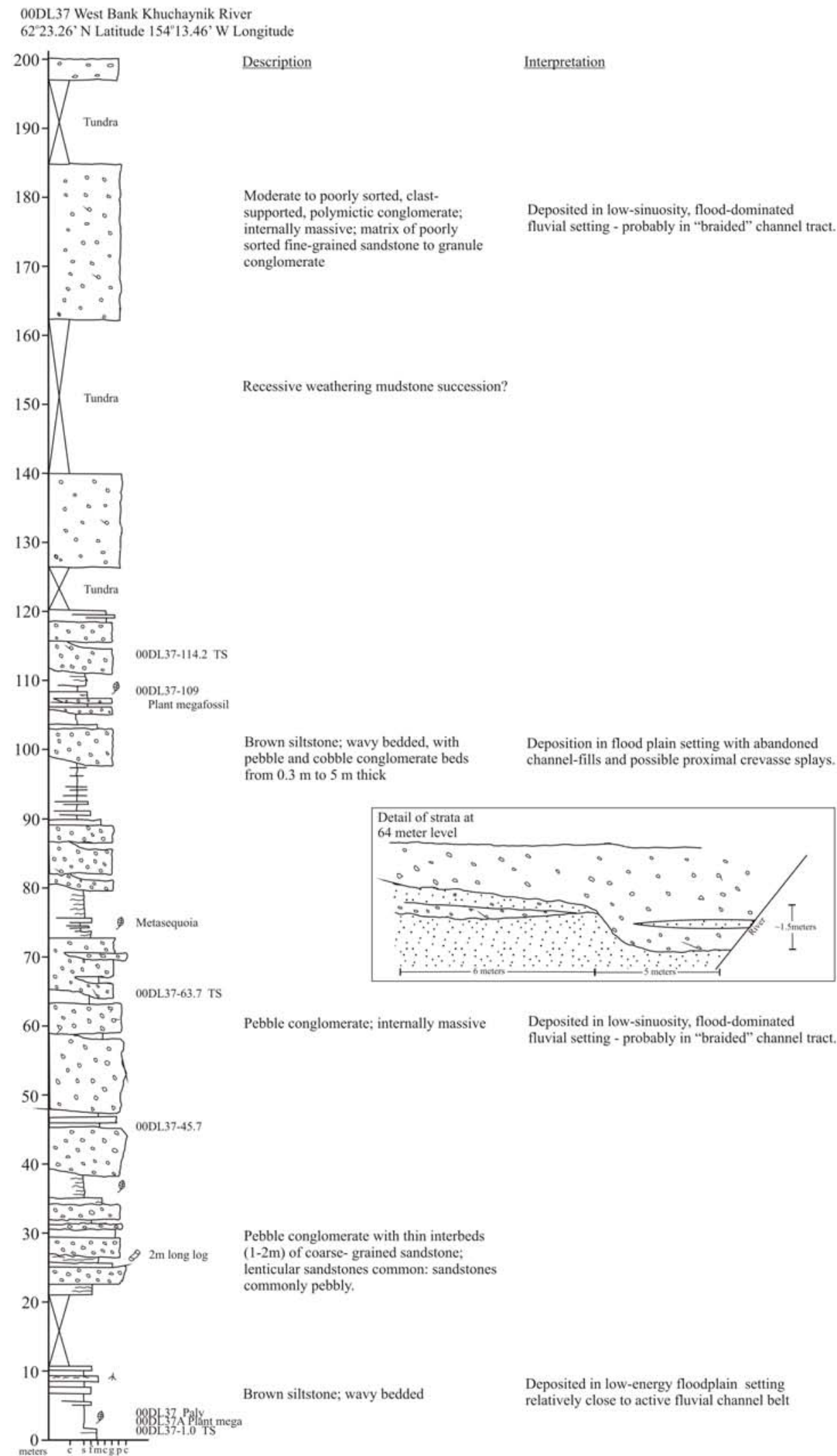

commonly pebbly.

Pebble conglomerate; internally massive

Deposited in low-sinuosity, flood-dominated fluvial setting - probably in "braided" channel tract.

20

10 Brown siltstone; wavy bedded $\quad \begin{aligned} & \text { Deposited in low-energy floodplain setting } \\ & \text { relatively close to active fluvial channel belt }\end{aligned}$

Figure 11. Measured section through part of Dickey's (1982) unit Tqa, showing probable early to middle Miocene strata. Measured by LePain, July 2000. 

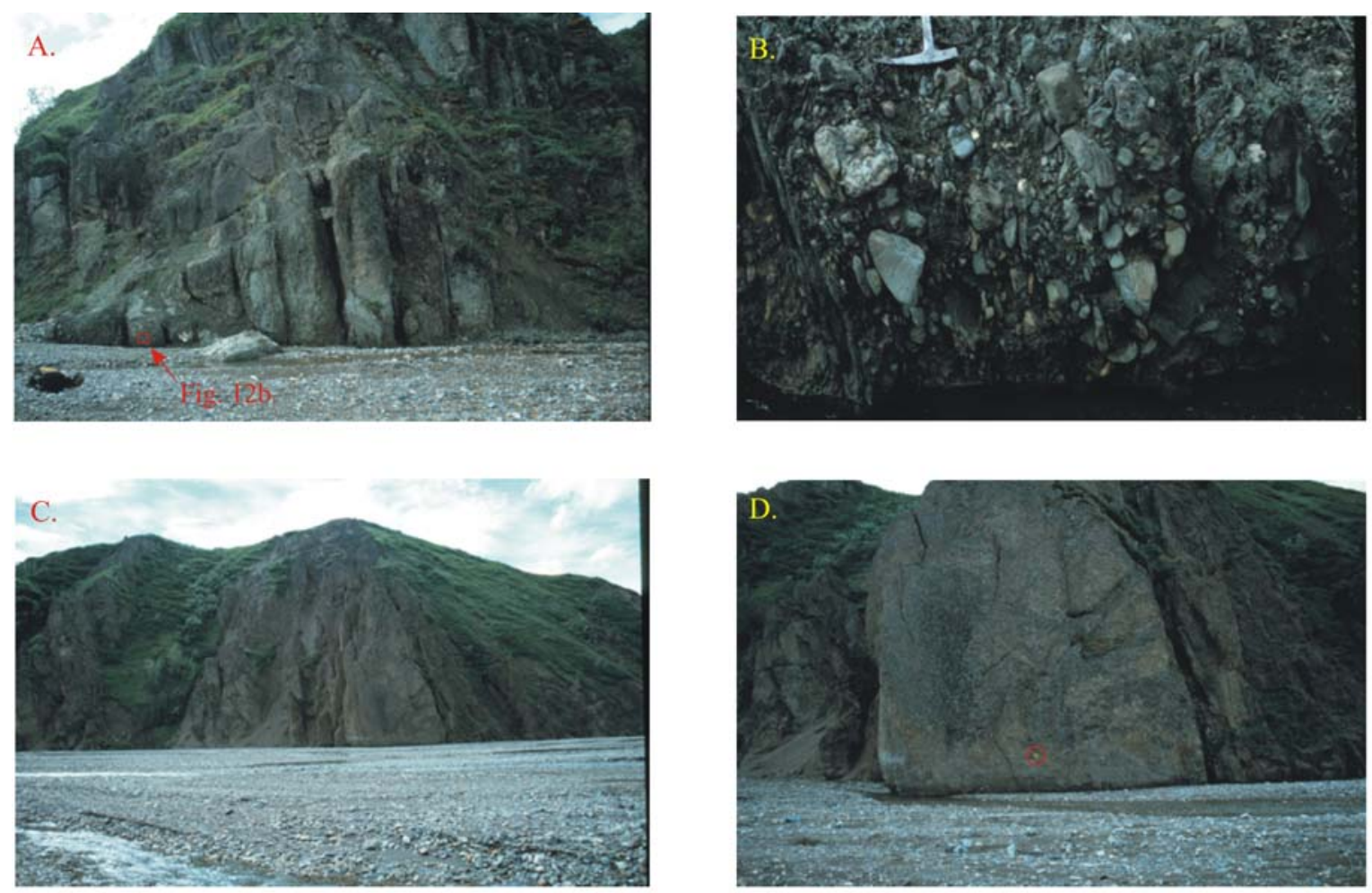

Figure 12. Selected photographs of the Tertiary section on the west bank of the Khuchaynik River. A. Near vertical pebble conglomerate beds exposed on the west bank of the Khuchaynik River at 00DL35. Unit corresponds to Dickey's Tcl. View toward the west-southwest Clasts are dominantly limestones similar to lithologies in the Dillinger sequence; B. Clast segregation based on size and shape in unit Tcl at 00DL35. Field of view is outlined by red box in Fig. 12a. Note distinct imbricate fabric in middle bed with platy clasts; C. Thick conglomerate beds exposed on the west bank of the Khuchaynik River at 00DL37. Succession shown corresponds to the $32 \mathrm{~m}-78 \mathrm{~m}$ interval in the measured section shown in Fig. 11. Organization and clast composition are similar to conglomerate succession on Middle and Windy forks; D. Thick conglomerate body ( $47 \mathrm{~m}$ to $64 \mathrm{~m}$ level in Fig. 11) with cryptic amalgamation surfaces exposed on the west bank of the Khuchaynik River at 00DL37. Note yellow field notebook for scale $(22 \mathrm{~cm}$ long) inside red circle. 


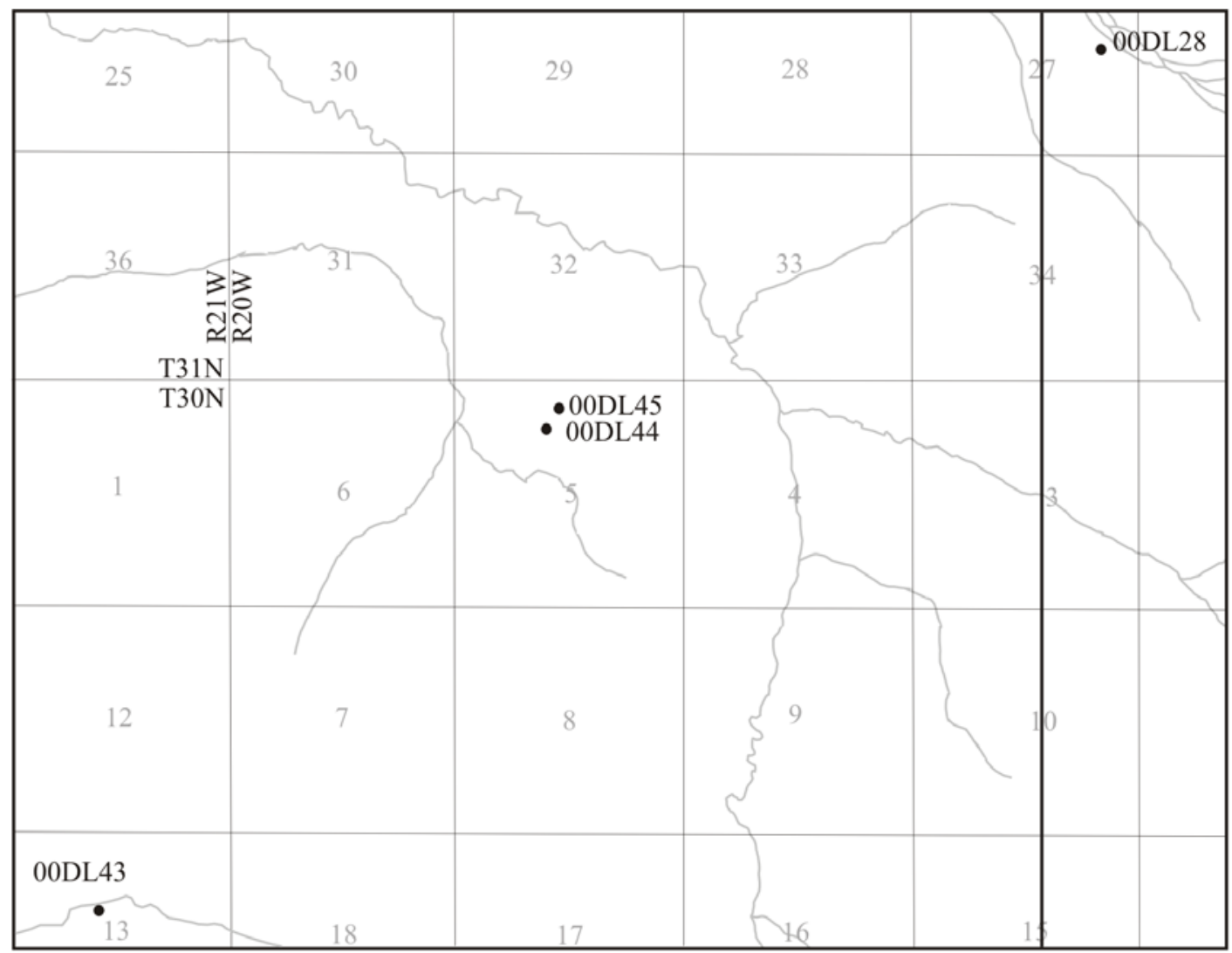

McGrath C-1 Quandrangle

Talkeetna C-6

Quadrangle

Figure 13. Map showing outcrop locations in the vicinity of the Little Tonzona River and Deepbank Creek in the McGrath C-1 and Talkeetna C-6 quadrangles. Boundary between the two quadrangles is shown by the heavy black vertical line near right side of map. Location 00DL43 is above the bank of a tributary to Deepbank Creek. Locations 00DL44 and 00DL45 are on the flanks of a northeast-trending rubble-covered hill located east of another tributary to Deepbank Creek. Location 00DL28 is on the west bank of the Little Tonzona River. The rubble at locations 00DL44 and 45 indicate that coal is probably continuous between the 00DL28 and 00DL43. 
00DL28 Little Tonzona River, Talkeetna C-6

$62^{\circ} 14.73^{\prime}$ North Latitude $152^{\circ} 59.27^{\prime}$ 'West Longitude

Silty clay shale; carbonaceous
Coal as below
Slightly silty clay shale
Yellowish white altered ash - bentonite

Coal as below

Silty claystone with plant fragments; concretions with plant framents Coal as below

Silty claystone

Silty claystone; weathers red-brown

Dark brown woody coal, lignite; abundant amber

Light gray to orange weathering altered ash at least $2 \mathrm{~m}$ thick

Figure 14. Measured section of probable early Oligocene coal-bearing strata exposed along the west bank of the Little Tonzona River. Samples are tied to measured section by last two digits of sample number (position is meters above base of section). 

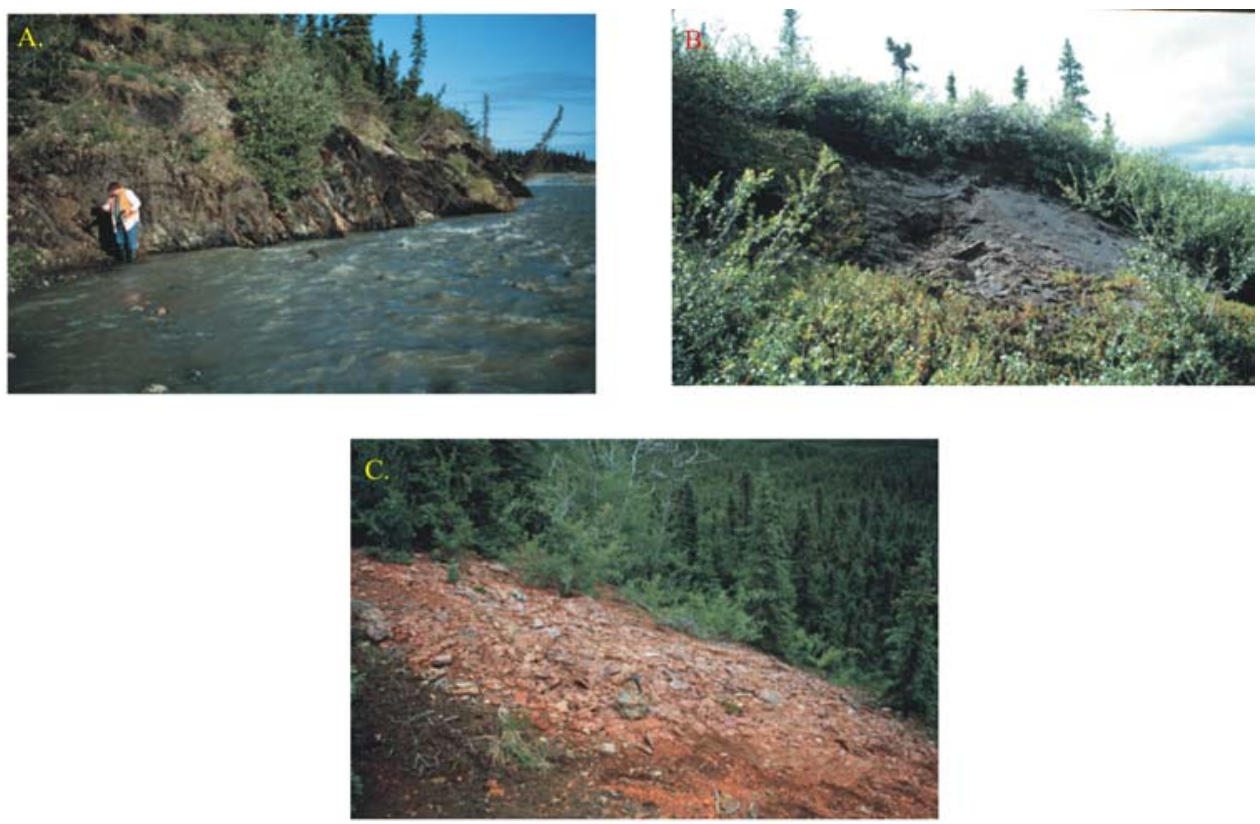

Figure 15. Selected photographs of the Tertiary section at the Little Tonzona River and Deepbank Creek. A. Steeply dipping coal seam exposed on the west bank of the Little Tonzona River at 00DL28, also shown in Fig. 14; B. Exposure of coal a few meters above the banks of Deepbank Creek at 00DL43; C. Helicopter view of rubblecrop of baked siltstone, very fine-grained sandstone, and altered volcanic ash between Deepbank Creek and the Little Tonzona River at 00DL45.

Rock-Eval Data for Tertiary Strata, McGrath Quadrangle

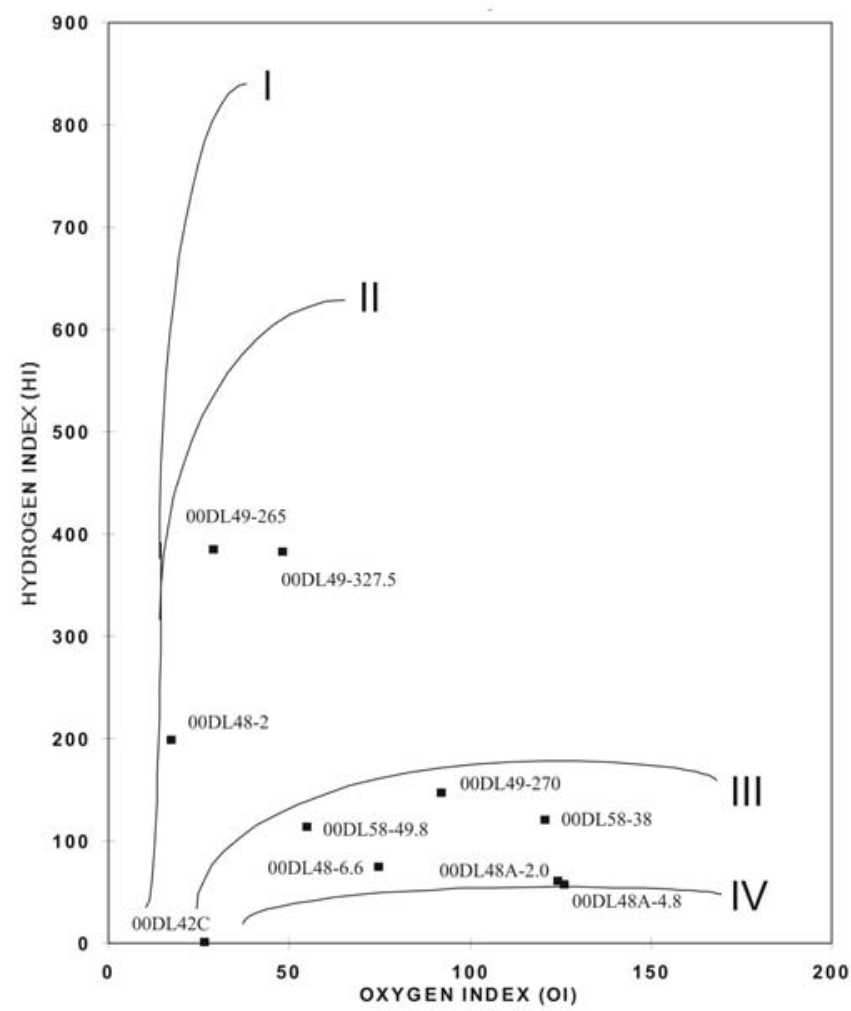

Figure 16. Kerogen type determination from total organic carbon and Rock-Eval pyrolysis data. Types I and II kerogen will generate oil and gas (if thermal maturity is high enough), type III will generate gas, and type IV will generate little or no hydrocarbons. Sample locations are shown in Fig. 2. 
Table 1. Coal quality data from Tertiary strata exposed along the Alaska Range mountain front between the Little Tonzona River and the Cheeneetnuk River, Alaska.

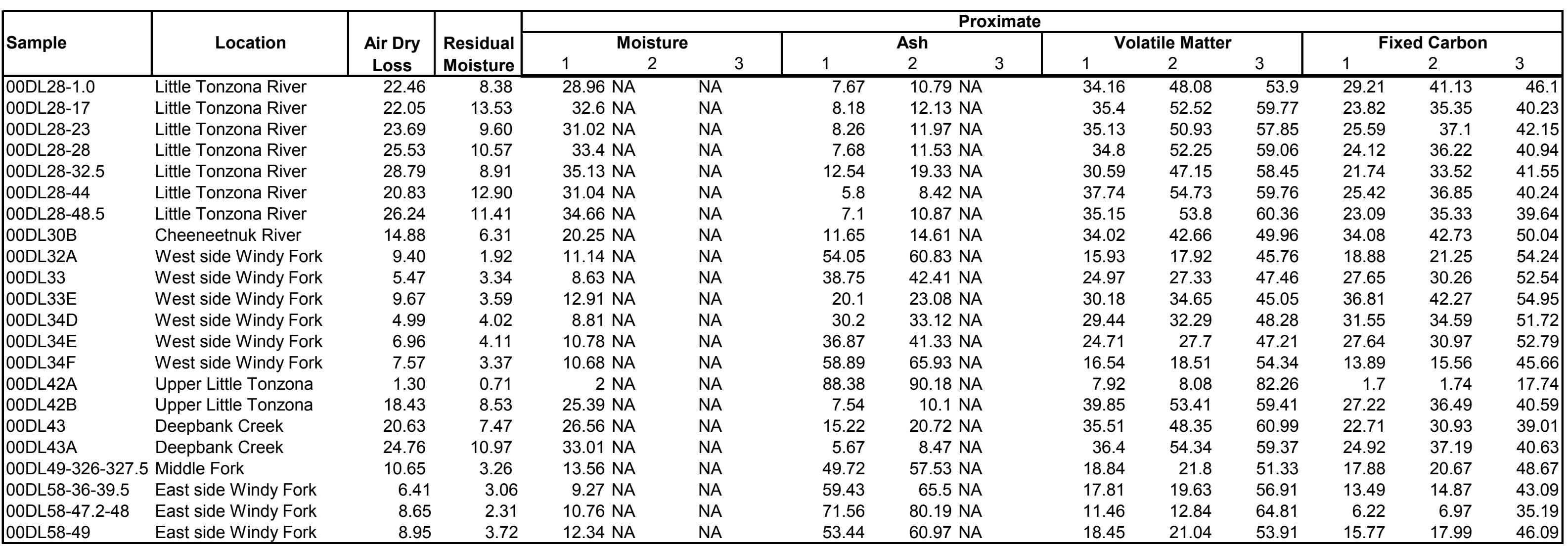

\begin{tabular}{|c|c|c|c|c|c|c|c|c|c|c|c|c|c|c|c|c|}
\hline \multirow{3}{*}{ Sample } & \multirow{2}{*}{\multicolumn{4}{|c|}{ Hydrogen }} & \multirow{2}{*}{\multicolumn{3}{|c|}{ Carbon }} & \multicolumn{9}{|c|}{ Ultimate } \\
\hline & & & & & & & & & rogen & & & ulfur & & & xygen & \\
\hline & 1 & & 2 & 3 & 1 & 2 & 3 & 1 & 2 & 3 & 1 & 2 & 3 & 1 & 2 & 3 \\
\hline $00 \mathrm{DL} 28-1.0$ & & 6.58 & 4.71 & 5.28 & 44.71 & 62.93 & 70.55 & 0.68 & 0.96 & 1.08 & 1.23 & 1.74 & 1.95 & 39.13 & 18.87 & 21.14 \\
\hline 00DL28-17 & & 6.87 & 4.78 & 5.44 & 40.7 & 60.38 & 68.72 & 0.67 & 0.99 & 1.13 & 1.1 & 1.5 & 1.71 & 42.57 & 20.22 & 23 \\
\hline 00DL28-23 & & 6.66 & 4.62 & 5.25 & 41.41 & 60.03 & 68.2 & 0.57 & 0.83 & 0.94 & 1.3 & 1.88 & 2.14 & 41.8 & 20.67 & 23.47 \\
\hline 00DL28-28 & & 6.83 & 4.64 & 5.24 & 39.59 & 59.44 & 67.19 & 0.38 & 0.57 & 0.64 & 1.26 & 1.89 & 2.14 & 44.26 & 21.93 & 24.79 \\
\hline 00DL28-32.5 & & 6.72 & 4.3 & 5.33 & 34.76 & 53.58 & 66.43 & 0.43 & 0.67 & 0.83 & 1.18 & 1.81 & 2.25 & 44.37 & 20.31 & 25.16 \\
\hline 00DL28-44 & & 6.72 & 4.71 & 5.15 & 41.55 & 60.25 & 65.79 & 0.44 & 0.64 & 0.7 & 0.84 & 1.22 & 1.33 & 44.65 & 24.76 & 27.03 \\
\hline 00DL28-48.5 & & 6.91 & 4.64 & 5.21 & 37.9 & 58 & 65.07 & 0.4 & 0.61 & 0.68 & 0.6 & 0.93 & 1.04 & 47.09 & 24.95 & 28 \\
\hline OODL30B & & 5.88 & 4.53 & 5.3 & 50.11 & 62.83 & 73.59 & 1.57 & 1.96 & 2.3 & 0.93 & 1.16 & 1.36 & 29.96 & 14.91 & 17.45 \\
\hline 00DL32A & & 3.2 & 2.2 & 5.61 & 25.03 & 28.17 & 71.92 & 0.7 & 0.79 & 2 & 0.15 & 0.17 & 0.44 & 16.87 & 7.84 & 20.03 \\
\hline 00DL33 & & 3.88 & 3.19 & 5.54 & 38.18 & 41.79 & 72.55 & 1.03 & 1.13 & 1.96 & 0.23 & 0.25 & 0.43 & 17.93 & 11.23 & 19.52 \\
\hline 00DL33E & & 5.22 & 4.33 & 5.63 & 51.47 & 59.1 & 76.83 & 1.22 & 1.4 & 1.82 & 0.25 & 0.29 & 0.38 & 21.74 & 11.8 & 15.34 \\
\hline 00DL34D & & 4.4 & 3.74 & 5.59 & 43.95 & 48.2 & 72.07 & 1.3 & 1.43 & 2.13 & 0.46 & 0.5 & 0.75 & 19.69 & 13.01 & 19.46 \\
\hline 00DL34E & & 4.02 & 3.15 & 5.37 & 36.98 & 41.44 & 70.64 & 1.05 & 1.18 & 2.01 & 0.35 & 0.4 & 0.68 & 20.73 & 12.5 & 21.3 \\
\hline 00DL34F & & 2.94 & 1.96 & 5.75 & 19.84 & 22.21 & 65.19 & 0.76 & 0.85 & 2.49 & 0.14 & 0.16 & 0.46 & 17.43 & 8.89 & 26.11 \\
\hline O0DL42A & & 0.79 & 0.57 & 5.85 & 4.06 & 4.14 & 42.15 & 0.17 & 0.17 & 1.74 & 0.01 & 0.01 & 0.1 & 6.59 & 4.93 & 50.16 \\
\hline OODL42B & & 6.26 & 4.59 & 5.1 & 43.18 & 57.88 & 64.38 & 0.56 & 0.75 & 0.84 & 0.38 & 0.5 & 0.56 & 42.08 & 26.18 & 29.12 \\
\hline 00DL43 & & 6.06 & 4.21 & 5.31 & 37.99 & 51.73 & 65.25 & 0.62 & 0.84 & 1.06 & 0.28 & 0.38 & 0.48 & 39.83 & 22.12 & 27.9 \\
\hline 00DL43A & & 6.72 & 4.52 & 4.94 & 39.96 & 59.65 & 65.17 & 0.53 & 0.79 & 0.86 & 0.47 & 0.7 & 0.76 & 46.65 & 25.87 & 28.27 \\
\hline O0DL49-326-327.5 & & 3.71 & 2.54 & 5.98 & 26.63 & 30.8 & 72.52 & 1.11 & 1.28 & 3.02 & 0.01 & 0.01 & 0.02 & 18.82 & 7.84 & 18.46 \\
\hline 00DL58-36-39.5 & & 2.99 & 2.15 & 6.24 & 21.16 & 23.32 & 67.61 & 0.81 & 0.9 & 2.6 & 0.1 & 0.11 & 0.33 & 15.51 & 8.02 & 23.22 \\
\hline 00DL58-47.2-48 & & 2.41 & 1.35 & 6.83 & 10.2 & 11.43 & 57.73 & 0.53 & 0.59 & 3 & 0.05 & 0.06 & 0.31 & 15.25 & 6.38 & 32.13 \\
\hline 00DL58-49 & & 3.35 & 2.25 & 5.76 & 23.46 & 26.77 & 68.57 & 0.94 & 1.07 & 2.74 & 0.15 & 0.17 & 0.43 & 18.66 & 8.77 & 22.5 \\
\hline
\end{tabular}

1 - As received

2- Dry

3 - Dry ash-free

Analyses by Geochemical Testing, 2005 N Center Ave., Somerset, PA 15501 
Table 2. Summary of Rock-Eval pyrolysis data for samples collected from Tertiary sedimentary rocks in the southern McGrath Quadrangle, Alaska. Analyses performed by Baseline-DGSI, Inc., Houston, TX.

\begin{tabular}{|c|c|c|c|c|c|c|c|c|c|c|c|c|c|}
\hline $\begin{array}{l}\text { SAMPLE } \\
\text { ID }\end{array}$ & LOCATION & $\begin{array}{l}\text { SAMPLE } \\
\text { LITHOLOGY }\end{array}$ & $\begin{array}{l}\text { SEDIMENTARY } \\
\text { FACIES }\end{array}$ & $\begin{array}{l}\text { TOC } \\
\text { Wt } \%\end{array}$ & $\begin{array}{c}\mathbf{S 1} \\
\mathrm{mg} / \mathrm{g}\end{array}$ & $\begin{array}{c}\mathrm{S} 2 \\
\mathrm{mg} / \mathrm{g}\end{array}$ & $\begin{array}{c}\mathrm{S} 3 \\
\mathrm{mg} / \mathrm{g}\end{array}$ & $\begin{array}{l}\text { Tmax } \\
\operatorname{deg} C\end{array}$ & $\begin{array}{l}\text { S1/ } \\
\text { TOC }\end{array}$ & HI & OI & $\begin{array}{l}\text { S2I } \\
\text { s3 }\end{array}$ & PI \\
\hline 00DL32F & Windy Fork & Carbonaceous claystone & Floodplain lake & 0.06 & 0.01 & 0.02 & 0.40 & 434 & 17 & 33 & 667 & 0.05 & 0.33 \\
\hline 00DL42C & S. Little Tonzona River & Fissile shale & Unknown & 1.62 & 0.02 & 0.02 & 0.43 & 558 & 1 & 1 & 27 & 0.05 & 0.50 \\
\hline 00DL42B & S. Little Tonzona River & Bituminous coal & Mire & & & & & & & & & & \\
\hline 00DL48-2 & Middle Fork & Claystone & Floodplain lake or swamp & 8.45 & 0.08 & 16.76 & 1.46 & 425 & 1 & 198 & 17 & 11.48 & 0.00 \\
\hline 00DL48-6.6 & Middle Fork & Claystone & Floodplain lake & 3.94 & 0.02 & 2.96 & 2.94 & 437 & 1 & 75 & 75 & 1.01 & 0.01 \\
\hline 00DL48A-2.0 & Middle Fork & Claystone & Floodplain lake or swamp & 1.32 & 0.01 & 0.80 & 1.64 & 437 & 1 & 61 & 124 & 0.49 & 0.01 \\
\hline 00DL48A-4.8 & Middle Fork & Claystone & Floodplain lake & 1.66 & 0.01 & 0.96 & 2.09 & 440 & 1 & 58 & 126 & 0.46 & 0.01 \\
\hline 00DL49-265 & Middle Fork & Carbonaceous claystone & Lacustrine & 15.25 & 0.57 & 58.80 & 4.44 & 418 & 4 & 386 & 29 & 13.24 & 0.01 \\
\hline 00DL49-270 & Middle Fork & Carbonaceous claystone & Lacustrine & 9.56 & 0.21 & 14.03 & 8.79 & 428 & 2 & 147 & 92 & 1.60 & 0.01 \\
\hline 00DL49-327.5 & Middle Fork & High-ash coal & Lacustrine & 15.76 & 0.86 & 60.32 & 7.57 & 410 & 5 & 383 & 48 & 7.97 & 0.01 \\
\hline 00DL58-38 & Windy Fork & Carbonaceous claystone & Floodplain lake or swamp & 3.09 & 0.04 & 3.72 & 3.73 & 432 & 1 & 120 & 121 & 1.00 & 0.01 \\
\hline 00DL58-49.8 & Windy Fork & Silty carbonaceous claystone & Floodplain lake or swamp & 1.57 & 0.01 & 1.79 & 0.86 & 428 & 1 & 114 & 55 & 2.08 & 0.01 \\
\hline
\end{tabular}

